2. To: (Receiving Organization)
Distribution

5. Proj./Prog./Dept./Div.:

TWRS ISD

8. Originator Remarks:

Document is being transmitted for release.
3. From: (originating organization) BCSR/ISS TWRS ISD

6. Cog. Engr.:

A. J. Calapristi
4. Related EDT Mo.:

$$
N / A
$$

7. Purchase Order No.:

$$
\text { N/A }
$$

9. Equip./Component Ho.:

$$
N / A
$$

10. System/Bldg./Facility:

$$
\text { N/A }
$$

11. Receiver Remarks:

12. Major Assm. Dwg. Mo.:

$$
\text { N/A }
$$

13. Permit/Permit Application No.: $N / A$

14. Required Response Date:

$$
N / A
$$

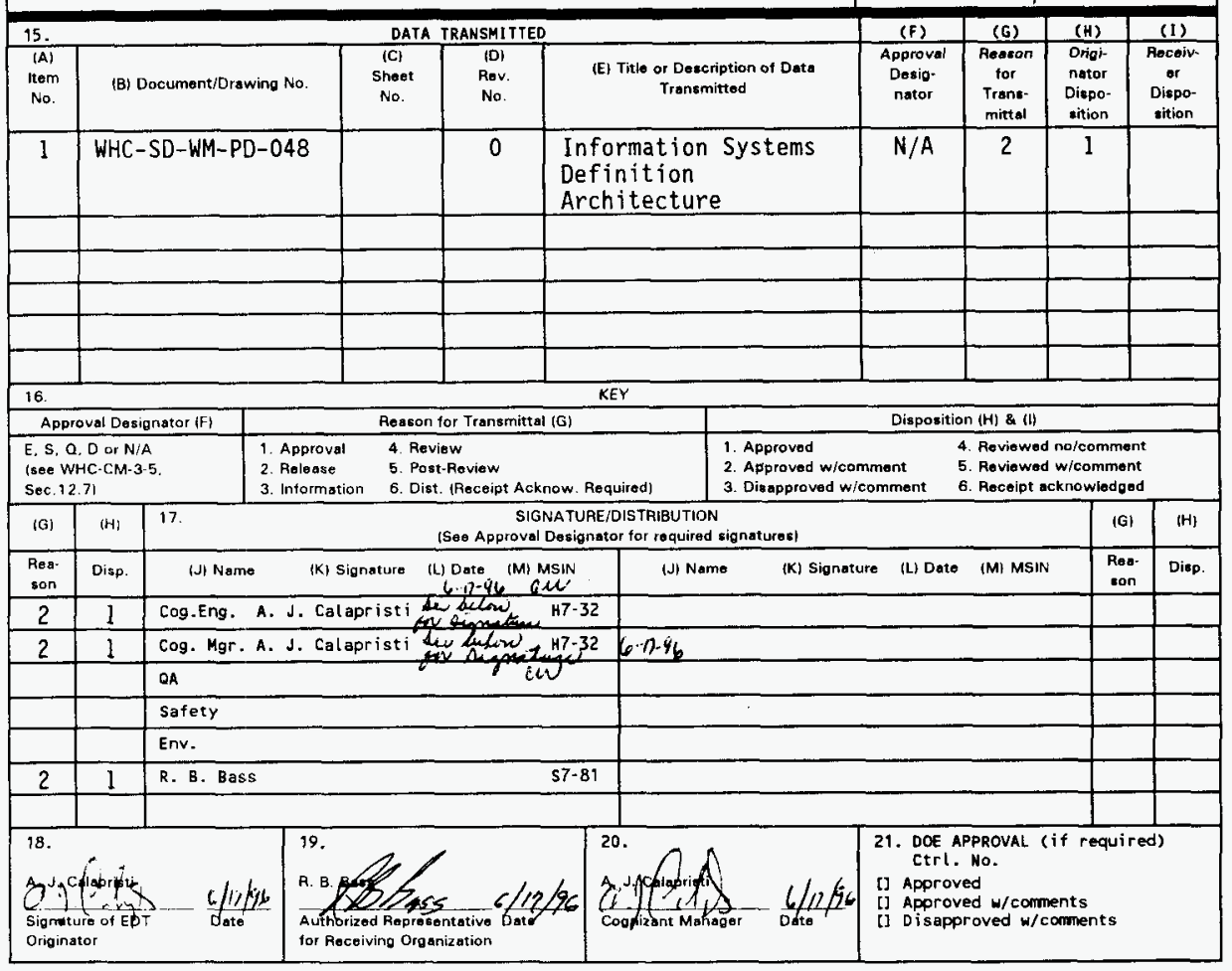




\section{Information Systems Definition Architecture}

\section{A. J. Calapristi}

West inghouse Hanford Company, Richland, WA 99352

U.S. Department of Energy Contract DE-AC06-87RL10930

\begin{tabular}{|c|c|c|}
\hline $\begin{array}{l}\text { EDT/ECN: } \\
\text { Org Code: } \\
\text { B\&R Code: }\end{array}$ & $\begin{array}{l}141260 \\
60100 \\
E W 3120075\end{array}$ & $\begin{array}{l}\text { UC: } 600 \\
\text { Charge Code: } \\
\text { Total Pages: }\end{array}$ \\
\hline
\end{tabular}

Key Words: IM, management, information architecture, process improvement, information requirements, IMSC

Abstract: The Tank Waste Remediation System (TWRS) Information Systems Definition architecture evaluated information management (IM) processes in several key organizations. The intent of the study is to identify improvements in TWRS IM processes that will enable better support to the TWRS mission, and accommodate changes in TWRS business environment. The ultimate goals of the study are to reduce IM costs, manage the configuration of TWRS IM elements, and improve IM-related process performance.

TRADEMARK DISCLAIMER. Reference herein to any specific comercial product, process, or service by trade name, trademark, manufacturer, or otherwise, does not necessarily constitute or imply its endorsement, recomendation, or favoring by the United States Government or any agency thereof or its contractors or subcontractors.

Printed in the United States of America. To obtain copies of this document, contact: WHC/BCS Document Control Services, P.O. Box 1970, Mailstop H6-08, Richland 4498352 Phone (500) 320-2130. Fax (509) 376-4989.
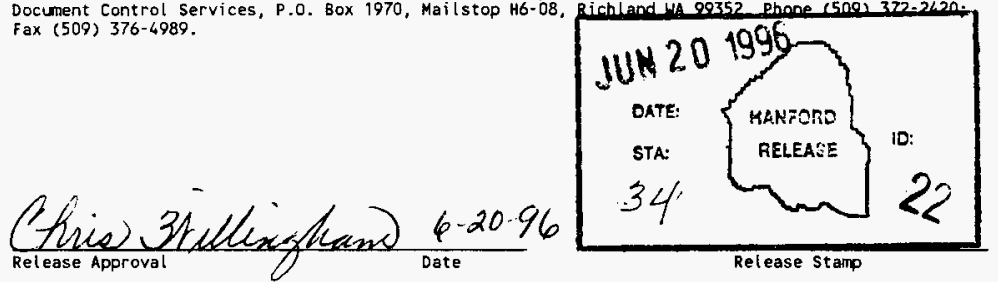

\section{Approved for Public Release}




\section{CONTENTS}

1.0 SUMMARY OF INFORMATION SYSTEMS DEFINITION (ISD) $\ldots \ldots \ldots \ldots$

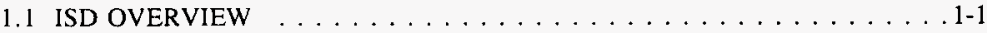

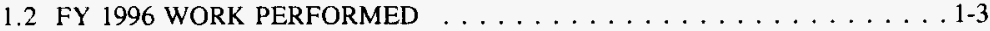

1.2.1 HLW Tank Characterization Process . . . . . . . . . . . 1-3

1.2 .2 TWRS Technical Integration Process .............. . . . . . . . . . . .

1.2 .3 O\&M Work Management Process . . . . . . . . . . . . . 1-4

1.2 .4 WTF Reengineering Simulation .................. 1-4

1.2 .5 IMSC . . . . . . . . . . . . . . . . . . . . . . . . . . .

1.3 STRATEGIC RECOMMENDATIONS $\ldots \ldots \ldots \ldots \ldots \ldots \ldots \ldots$

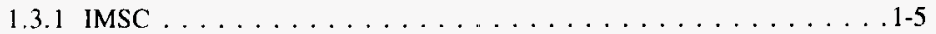

1.3 .2 IM Business Plan . . . . . . . . . . . . . . . . . . . . . . .

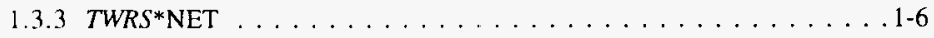

1.3 .4 Data Integration . . . . . . . . . . . . . . 1-6

1.3 .5 Program Management . . . . . . . . . . . . . 1-6

1.4 INTRODUCTION TO ISD MODELING TECHNIQUES . . . . . . . . 1-7

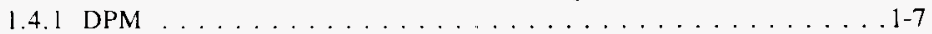

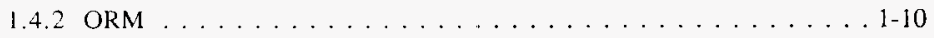

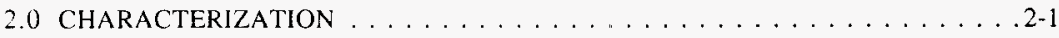

2.1 EXECUTIVE SUMMARY . . . . . . . . . . . . . . . .

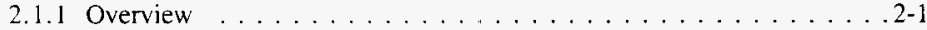

2.1.2 Significant Problems/Gaps . . . . . . . . . . . . . . . 2-2

2.1.3 Next Steps/Recommendations ... . . . . . . . . . . . 2-3

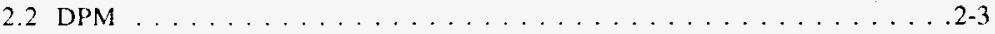

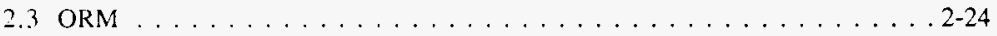

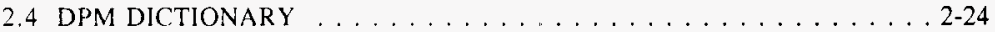

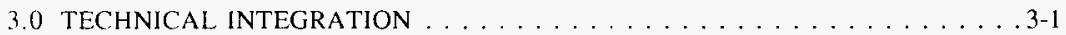

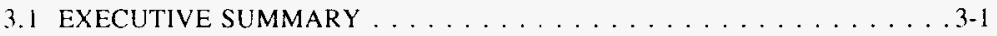

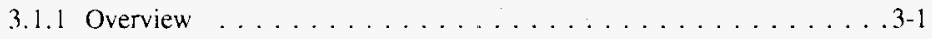

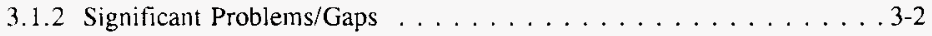

3.1.3 Next Steps/Recommendations . . . . . . . . . . . . . . 3-3

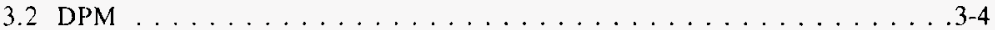

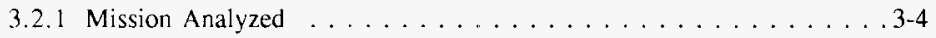

3.2 .2 F\&R Analyzed . . . . . . . . . . . . . . . . . . . . . . . . . . . . . . . . .

3.2 .3 Alternatives Generated . . . . . . . . . . . . . . . . 3-5

3.2 .4 Alternatives Evaluated and Optimized . . . . . . . . . . . . 3-6

3.2 .5 Architecture Selected . . . . . . . . . . . . . . 3-6

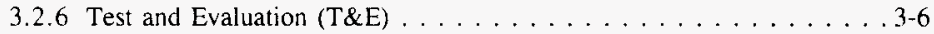

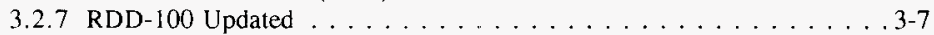

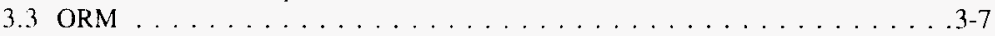

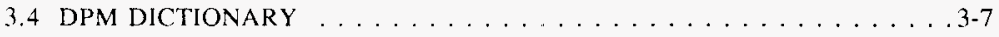




\section{WHC-SD-WM-PD-048 REV 0}

\section{CONTENTS (cont)}

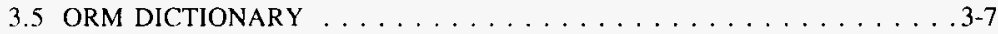

4.0 O\&M WORK MANAGEMENT PROCESS . . . . . . . . . . . . 4-1

4.1 EXECUTIVE SUMMARY . . . . . . . . . . . . . . . . . 4-1

4.1 .1 Overview ....................

4.1.2 Significant Problems/Gaps . . . . . . . . . . . . . . 4-1

4.1.3 Next Steps/Recommendations . . . . . . . . . . . 4-2

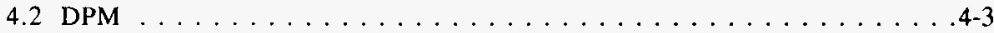

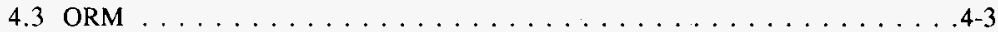

4.4 DPM DICTIONARY $\ldots \ldots \ldots \ldots \ldots \ldots \ldots \ldots \ldots \ldots \ldots .4 \ldots \ldots \ldots \ldots$

4.5 ORM DICTIONARY . . . . . . . . . . . . . . .4-4

5.0 WTF REENGINEERING SIMULATION $\ldots \ldots \ldots \ldots \ldots \ldots \ldots$. . . . . .

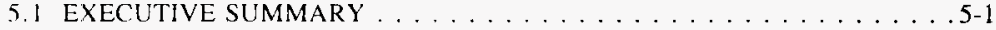

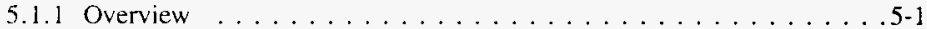

5.1 .2 Significant Problems/Gaps . . . . . . . . . . . . 5-2

5.1 .3 Next Steps/Recommendations . . . . . . . . . . . . . 5-2

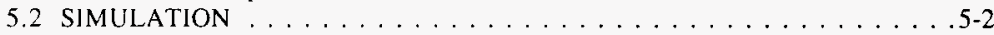

5.2 .1 Simulation Tasks . . . . . . . . . . . . . . .5-3

5.2 .2 Simulation Models . . . . . . . . . . . . . . . .5-3

5.2 .3 Simulation Resources . . . . . . . . . . . . . . . . 5-9

6.0 REFERENCES . . . . . . . . . . . . . . . . . . . .6-1 


\section{WHC-SD-WM-PD-048 REV 0}

\section{LIST OF FIGURES}

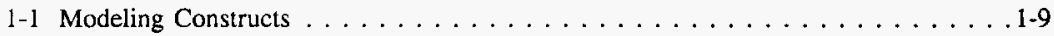

1-2 Sample Dynamic Process Model . . . . . . . . . . . . . . . . . 1-9

2-1 Tanks Characterized Event Dynamic Process Model $\ldots \ldots \ldots \ldots . . \ldots$. . . . . .

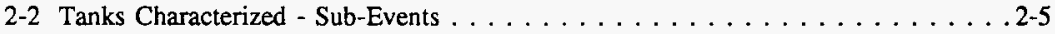

2-3 Data Quality Objectives Developed Dynamic Process Model - Sub-Event Flow . . 2 2-7

2-4 Data Quality Objectives Developed - Sub-Events . . . . . . . . 2-8

2-5 Sampling Requirements Developed - Sub-Event $\ldots \ldots \ldots \ldots$. . . . . . 2-13

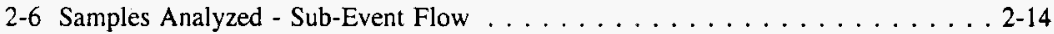

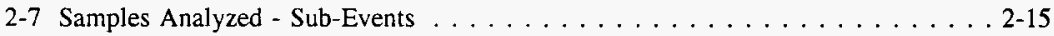

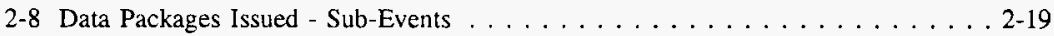

2-9 Tank Characterization Report Issued - Sub-Events . . . . . . . . . 2-21

2-10 Tank Characterization Report Published - Sub-Events $\ldots \ldots \ldots \ldots$ 2-23

2-11 Object Relationship Model - Participant Overview . . . . . . . . 2-25

2-12 Object Relationship Model - Participant Detail . . . . . . . . . . . 2-26

3-1 Systems Engineering Process Dynamic Process Model Context Level . . . . . . 3-8

3-2 Systems Engineering Process Dynamic Process Model Detail Level . . . . . . . 3-9

3-3 Systems Engineering Process Dynamic Process Model Object

Relationship Model . . . . . . . . . . . . . . . . . . . . 3-14

4-1 Work Management Dynamic Process Model $\ldots \ldots \ldots \ldots \ldots \ldots$. . . . . . . .

4-2 Work Management Object Relationship Model . . . . . . . . . . . . . . 4-8

5-1 West Tank Farms As-Is Work Document Processes . . . . . . . . . . . . 5-4

5-2 West Tank Farms To-Be Work Document Processes $\ldots \ldots \ldots$. . . . . . . 5-7 
WHC-SD-WM-PD-048 REV 0

\section{LIST OF TABLES}

2-1 Dynamic Process Model Dictionary . . . . . . . . . . . . . . . 2-39

2-2 Object Relationship Model Dictionary . . . . . . . . . . . . . . . 2-60

3-1 Program-Level Systems Engineering Technical Documents . . . . . . . . . 3-18

3-2 Project Systems Engineering Technical Documents . . . . . . . . . . . . . 3-19

3-3 Dynamic Process Model Dictionary . . . . . . . . . . . . . . . . . . 3-20

3-4 Object Relationship Model Dictionary . . . . . . . . . . . . . . . . 3-23

4-1 Dynamic Process Model Dictionary . . . . . . . . . . . . . 4-11

4-2 Object Relationship Model Dictionary . . . . . . . . . . . . . . . 4-15

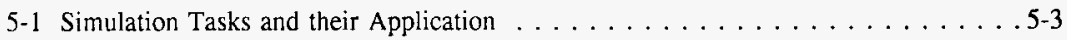

$5-2$ Simulation Resource Types and Locations . . . . . . . . . . . . . . . . . 5-9 


\section{LIST OF TERMS}

$\begin{array}{ll}\text { ACE } & \text { Analytical Card Enhancement } \\ \text { AGA } & \text { alternative generation and analysis } \\ \text { BCSR } & \text { BCS Richland, Inc. } \\ \text { BOA } & \text { Basic Ordering Agreement } \\ \text { BSD } & \text { baseline system description } \\ \text { COC } & \text { Chain-of-Custody } \\ \text { COG } & \text { cognizant manager and engineer } \\ \text { D\&D } & \text { decontamination and decommissioning } \\ \text { D\&DR } & \text { decontamination and decommissioning review } \\ \text { DDR } & \text { definitive design review } \\ \text { DNFSB } & \text { Defense Nuclear Facilities Safety Board } \\ \text { DOE } & \text { U.S. Department of Energy } \\ \text { DOE-HQ } & \text { U.S. Department of Energy-Headquarters } \\ \text { DOH } & \text { Washington State Department of Health } \\ \text { DPM } & \text { dynamic process model } \\ \text { DQO } & \text { data quality objective } \\ \text { DRD } & \text { design requirements document } \\ \text { DRR } & \text { design requirements review } \\ \text { DSC } & \text { differential scanning calorimeter } \\ \text { DSCG } & \text { differential scanning calorimeter graph } \\ \text { DST } & \text { double-shell tank } \\ \text { ECN } & \text { Engineering Change Notice } \\ \text { ECOlogy } & \text { Washington State Department of Ecology } \\ \text { EDT } & \text { Engincering Dara Transmitral } \\ \text { EPA } & \text { U.S. Environmental Protection Agency } \\ \text { F\&R } & \text { functions and requirements } \\ \text { FDS } & \text { Financial Data System } \\ \text { FRD } & \text { functions and requirements document } \\ \text { FY } & \text { fiscal year } \\ \text { GFAA } & \text { graphite furnace atomic absorption } \\ \text { HLW } & \text { high-level waste } \\ \text { HTCE } & \text { historical tank contents estimate } \\ \text { ICD } & \text { interface control document } \\ \text { ICF KH } & \text { ICF Kaiser Hanford Company } \\ \text { ICP } & \text { inductively coupled plasma } \\ \text { ID } & \text { identifier } \\ \text { IM } & \text { Information Management } \\ \text { Information Management Steering Committee } & \text { Information Release Request } \\ \text { information systems definition } \\ \text { Job Control System } \\ \text { DOS }\end{array}$




\section{LIST OF TERMS (cont)}

$\begin{array}{ll}\text { MACTEC } & \text { MAC Technical Services Company } \\ \text { MCR } & \text { mission complete review } \\ \text { NRC } & \text { U.S. Nuclear Regulatory Commission } \\ \text { O\&M } & \text { Operations \& Maintenance } \\ \text { ORM } & \text { object relationship model } \\ \text { ORR } & \text { operations readiness review } \\ \text { OSD } & \text { operational safety directive } \\ \text { PDR } & \text { preliminary design review } \\ \text { PHMC } & \text { Project Hanford Management Contractor } \\ \text { PIC } & \text { Person in Charge } \\ \text { PM } & \text { preventive maintenance } \\ \text { PMCS } & \text { Program Management Control System } \\ \text { PNNL } & \text { Pacific Northwest National Laboratory } \\ \text { QA } & \text { Quality Assurance } \\ \text { QC } & \text { quality control } \\ \text { RCR } & \text { Review Comment Record } \\ \text { RL } & \text { U.S. Department of Energy, Richland Operations Office } \\ \text { RMACS } & \text { Requirements Management and Assured Compliance System } \\ \text { SACS } & \text { Surveillance Analysis Computer System } \\ \text { SAP } & \text { sampling and analysis plan } \\ \text { SD } & \text { supporting document } \\ \text { SDR } & \text { system design review } \\ \text { SE } & \text { systems engineering } \\ \text { SID } & \text { state identifier } \\ \text { SRR } & \text { system requirements review } \\ \text { T\&E } & \text { test and evaluation } \\ \text { TCD } & \text { Tank Characterization Database } \\ \text { TCP } & \text { tank characterization plan } \\ \text { TCR } & \text { tank characterization report } \\ \text { TCRC } & \text { Tank Characterization Resource Center } \\ \text { TEP } & \text { technology evaluation plan } \\ \text { TGA } & \text { thermo-gravimetric analysis } \\ \text { TRR } & \text { technical requirements review } \\ \text { TRS } & \text { technical requirements specification } \\ \text { TWAP } & \text { tank waste analysis plan } \\ \text { TWRS } & \text { Tank Waste Remediation System } \\ \text { WHC } & \text { Westinghouse Hanford Company } \\ \text { WTF } & \text { West Tank Farms } \\ & \end{array}$


WHC-SD-WM-PD-048 REV 0

\section{INFORMATION SYSTEMS DEFINITION ARCHITECTURE}

\subsection{SUMMARY OF INFORMATION SYSTEMS DEFINITION (ISD)}

\subsection{ISD OVERVIEW}

The U.S. Department of Energy (DOE), Richland Operations Office (RL) requested a Tank Waste Remediation System (TWRS) ISD study to define a strategy for improving Information Management (IM) processes. Goals of the study were to bring down IM costs, manage the configuration of TWRS IM elements, and improve IM-related process performance. The study involved participants from RL, Westinghouse Hanford Company (WHC), BCS Richland, Inc. (BCSR), Pacific Northwest National Laboratory (PNNL), MAC Technical Services Company (MACTEC), ICF Kaiser Hanford Company (ICF KH), and DMR； Inc.

The ISD architecture provides TWRS with a framework within which TWRS IM development, procurement, and implementation activities can occur. The ISD architecture exploits change by defining information, technology, work, and application components and their interfaces so that new technologies can replace old ones with minimal impact to the overall system. This enables the IM function to more readily respond to changes in TWRS business.

In fiscal year (FY) 1995, the TWRS ISD Project analyzed IM processes spanning the entire life cycle of the information system from data collection or creation to dissemination and archival. The analysis included paper- and computer-based systems. The results of this study were reported in WHC-SD-WM-PLN-099, TWRS Information Systems Definition Engineering Study and Implementation Plan (Carriera 1995). The As-Is architecture describes how the elements of TWRS IM fit together today. The highlights are as follows.

- Information Management is not well understood and is often considered a low priority. In general, TWRS does not view IM as part of its overall business system. Budget cuts are applied to IM without understanding the effect on the total TWRS.

- Information Management costs are dispersed, often hidden, and inadequately tracked or managed. Information systems that span program elements are difficult to implement because funding often does not cross project boundaries.

- Many databases, but few information systems, exist throughout TWRS. Many informal data sources are used; however, the data are often not trusted. Many

DDMR is a trademark of DMR Group. Inc. 
opportunities exist to misinterpret raw data, resulting in added costs for validating the quality of data upon retrieval.

- Manual, paper-based systems are trusted more than automated systems. Several automated systems are paralleled by older, paper-based systems.

- Projectization causes organizations to focus on their own work scope without proper emphasis on integration between projects. This high degree of autonomy between projects results in a lack of standards, poor systems integration, and data incongruencies. Information Management project prioritization is done separately by each program element manager. Poor communication wastes time and effort.

Based on the overall FY 1995 "As-Is" analysis, a "To-Be" architecture was developed. A standards and principle-based approach was selected for the To-Be architecture instead to accommodate the dynamics of TWRS internal and external influences. The To-Be architecture focused on defining the needed standards for the management of information and the principles by which data should be created, managed, and used. The principles on which the architecture is based are as follows.

- Priority will be given to enhancing and developing information systems that contribute to TWRS business strategies and maximize operational effectiveness.

- When developing new or enhancing existing information systems, simplifying business practices takes precedence over automation.

- Before automating, business practices must be documented with process models and validated.

- ISD architecture principles and resulting policies must be followed to ensure that data can be gathered and distilled into information that can be shared.

- Data will be entered only once.

- Data will be accessible to all authorized TWRS users with appropriate safeguards against unintentional or unauthorized alteration, destruction, and disclosure.

- Common information systems will be deployed among all TWRS business units unless specific analysis establishes that they should be unique.

- A plan and business case must be prepared before information systems are developed and significant IM activities funded.

- TWRS personnel are responsible for the success of their information systems and accountable for their IM-related expenses. Development of information systems 
products and other IM activities should be led and continuously improved under the joint stewardship of the TWRS Information Officer and the TWRS Project sponsor.

- Inventory data are technically defensible, provide adequate change control, and are easily accessible in one location. Supporting data are adequate and data qualifiers are in place.

The FY 1996 ISD work focused on key process within the TWRS Program and addressed specific issues and problems identified in FY 1995. The areas of focus were as tollows:

- High-level waste (HLW) tank characterization process

- TWRS Technical Integration process

- Operations and Maintenance (O\&M) work management process

- West Tank Farms (WTF) reengineering simulation

- Information Management Steering Committee (IMSC).

\subsection{FY 1996 WORK PERFORMED}

\subsubsection{HLW Tank Characterization Process}

The FY 1996 As-Is analysis was performed in two phases. Phase 1 focused on the generation process of the tank characterization reports (TCR) and resulted in WHC-SD-WM-PD-045, Tank Waste Remediation System Information Systems Definition Tank Characterizarion Repom Generarion Process As-Is (Legore 1996). The goal of Phase 1 was to identify specific opportunities for improving the TCR process and shortening the time required to issue the document. Phase 2, documented in this report, adds details about other key characterization areas, e.g., data quality objectives (DQO), sample analysis, and data reporting, while retaining the information developed in Phase 1.

\subsubsection{TWRS Technical Integration Process}

The TWRS mission is to store, treat, and immobilize highly radioactive Hanford Site waste (current and future tank waste and the encapsulated cesium and strontium) in a safe, environmentally sound, and cost-effective manner. The mission includes retrieval, pretreatment, immobilization, interim storage and disposal, and tank closure. The TWRS uses a combined program and technical management approach to develop an integrated baseline that combines the cost, schedule, and technical baseline for remediating the tank waste. 
The dynamic process models (DPM) and object relationship models (ORM) for the Technical Integration organization address the processes that formulate the technical baseline (i.e., scope and technical information). These models were derived from WHC-SD-WM-SEMP-002, TWRS Systems Engineering Management Plan (Peck 1996) and through interviews with systems engineers within Technical Integration. Emphasis is given to the initial stages of the Systems Engineering (SE) process which produces program-level deliverables. Later stages of the SE process produce project-level deliverables. These project-level deliverables are addressed in the ORM but not in the DPM.

\subsubsection{O\&M Work Management Process}

An analysis was performed to document the current or As-Is processes of the O\&M work management process. The goal was to document the existing subprocesses, and to identify specific opportunities for improving the work management process and shortening the time required for completion of the work package document life cycle.

The work management process is a uniform, graded approach to safely and effectively manage work that impacts facility operations. This process ensures work is properly identified, planned, scheduled, safely performed, and completed. Emphasis is placed on maintenance of configuration control in the facility, in addition to proper work management for facilities and equipment. The definition of work includes modification and construction work, and corrective, preventive, and predictive maintenance.

\subsubsection{WTF Reengineering Simulation}

West Tank Farms, as part of its reengineering effort, identified 11 goals it wanted to achieve to create and maintain a clean, safe, and stable operating environment. The two goals identified as being candidates for simulation using the ISD modeling techniques are as follows.

- Reduce detailed work planning preparation cycle time by $50 \%$.

- Reduce the number of jobs/tasks requiring detailed planning by $80 \%$.

The objectives were to (1) simulate the current or As-Is processes of the WTF, (2) compare the simulated results obtained from the model with metrics of the actual results currently achieved, and (3) create a simulation model of the To-Be or desired organizational processes to postulate the time, level of effort, and organization required to reduce the work planning document cycle time. The simulations are discussed in Section 5.0. 


\subsubsection{IMSC}

The FY 1995 ISD identified the creation of a TWRS IMSC as critical to the implementation of the To-Be architecture and continued change. The ISD recommended that the IMSC be formed to set the direction of IM in TWRS, prioritize IM activities, and make the funding recommendations that would lead to more cost-effective TWRS IM. The ISD provided the IMSC with a consolidated activity list of current and proposed IM projects. The TWRS study defined the work management processes for identifying and proposing IM projects and for decision making, funding, and project startup.

The TWRS IMSC met for the first time in January 1996. The purpose of the workshop was to create the IMSC team and to initiate IMSC business. Roger Bacon, manager of TWRS, characterized the IMSC participants as the business managers of the IM business and as the decision makers for TWRS IM. He explained his expectations for the integration of IM across projects and stated that the ensuing value-added is of paramount importance to the program.

The ISD team facilitated the creation of the IMSC and the general process for operation of the committee.

\subsection{STRATEGIC RECOMMENDATIONS}

\subsubsection{IMSC}

An immediate objective for the ISD team, working with the IMSC, is to develop and establish the process for implementation of IMSC decisions and policies in the form of projects. This will require additional work with the IMSC to establish a single overall owner within TWRS for the data management function. This owner would be responsible for establishing data management standards and integrating the various IM functions across TWRS.

\subsubsection{IM Business Plan}

An IM business plan will be developed to guide the FY 1997 IM activities within TWRS. The basis for the IM business plan is this report and the supporting document (SD) describing the details of the As-Is analysis. The IM business plan must be approved by the TWRS Chief Information Officer and will serve as the primary vehicle for implementing the remainder of the next steps described in the following subsections. 


\subsubsection{TWRS*NET}

Many companies are using Internet technologies to manage information on their internal company networks. These web browser-based systems, called "Intranets," are expected to grow dramatically during the next few years. Development and implementation of a plan for growth are required to ensure that the TWRS Intranet evolves into a vehicle for disseminating high-quality TWRS information. The ISD Project, in conjunction with the data management process sponsor, should design the information structure of the underlying data sources that feed information to the Intranet web pages. Configuration management practices and change control of the Intranet should be included.

TWRS*NET is a concept for designing and building an internal network for distribution of controlled, traceable, and reliable TWRS technical and programmatic information. The TWRS*NET will provide the user with a common user interface to access TWRS data. It will appear as a collection of web pages structured and aligned with the business processes of TWRS. More importantly, it will address the "behind the scenes" functions that are used to locate and link the disparate data sources in TWRS into the visible web pages and applications software. Standards will be developed to ensure that TWRS*NET data are of known quality and pedigree.

\subsubsection{Data Integration}

The data management sponsor within TWRS will perform the data integration across TWRS, specifically the following activities.

- Identify the data that will pass across functional boundaries and interfaces.

- Develop data standards.

- Identify and establish data generators, owners, custodians, and users.

- Prepare for contractor transition after the competition for the Management and Integration Contract is complete.

- Develop contract requirements for enforcing the use of data standards and the Intranet across subcontractor boundaries.

\subsubsection{Program Management}

The TWRS Program Management Control System (PMCS) is being implemented as the primary information system for the management of the technical, cost, and schedule baseline process within TWRS. The TWRS Program/Project management process is to be embodied in the PMCS. 
The PMCS software is custom developed by external vendors in accordance with WHC specification. Several major modules of the system are operational but others are needed to reach full functionality. Portions of the system are partially redundant or overlapping with existing WHC systems. The system engineering technical baseline work process needs to be factored into the overall program management process in TWRS as well as site-wide. However, the PMCS offers a significant improvement toward technical/cost and schedule integration of multiple projects over the existing Financial Data System (FDS) and construction project systems.

Uncertainties regarding the future of the PMCS are primarily dependant upon the management control system processes and tools adopted by the new Project Hanford Management Contractor (PHMC).

A single information system needs to be established as the Site standard, and brought into alignment with the Site business management system architecture. The TWRS PMCS should be considered as one of the candidates for the Site PMCS.

Before the start of the transition with the new PHMC, a small PMCS task team should be chartered by the TWRS IMSC to determine whether the TWRS PMCS should become the Site PMCS. This team would consist of TWRS personnel, BCSR personnel, a TWRS ISD member, and a few non-TWRS personnel. During the transition period, the PMCS could be presented to the PHMC as a possible alternative for the Site integration of project management information.

\subsection{INTRODUCTION TO ISD MODELING TECHNIQUES}

Sections 2.0, 3.0, 4.0 and 5.0 describe the As-Is analysis for Characterization, Technical Integration, O\&M Work Management, and WTF Reengineering Simulation. The sections present descriptions of the As-Is architecture from a process viewpoint (DPM) and from an information viewpoint (ORM). The tables in each section provide textual descriptions, keyed to the figures, of the events and participants in the models. Section 6.0 references documents supporting the ISD As-Is analysis.

\subsubsection{DPM}

A DPM is a representation of a process as a sequence of events (circles). The DPM also shows the participants (rounded rectangles) which interact within the processes represented by the events. The operational relationships that exist between events and participants, and the precedence relationships that exist between events, are represented by lines with arrowheads.

A DPM may represent a process by means of increasing levels of detail. Thus, a single event, "Tanks Characterized," representing the total scope of Waste Tank 
Characterization can be broken down into a series of separate sub-events. Each of these sub-events can be broken down further into as many sub-levels as desired to fully document the operations under analysis.

An event always represents a business objective achieved, i.e., the completion of an activity or collection of activities. An event, by definition, causes change, over a specified period of time, of specific resources into specific products by specific agents according to the specified rules of the event. An event represents a change that is observable, measurable, and countable. Events are represented as noun-verb past tense descriptions and describe the primary result attained.

A participant, represented by a rounded rectangle, is a type of physical or abstract object. Participants represent types of objects and not individual instances. Participants can exist in multiple states, thus a report participant may be in "draft," "reviewed," "approved," and "released" states. The specitic state is identified by a specific state number and a label, shown in parentheses, at the bottom of the participant icon.

Each combination of participant name and state is considered to be a unique participant in the DPM (see Figure 1-1). Participant behaviors are as follows:

- Consumed by an event ("used") which is represented by an arrow going from the participant to the event

- Undergo a state change or are created by an event ("changed") which is represented by an arrow going from the event to the participant

- Enable the event to occur ("do") which is represented by a double-headed arrow.

Each event and each unique participant are assigned an identifier (ID) number. There is no relation between event ID numbers and participant ID numbers. No sequence or location in the model structure is implied. In the case of participants within multiple states, uniqueness is guaranteed by use of the "state number." The event and participant descriptions in this document are accompanied by their ID numbers (in parentheses).

The following describes how to read the sample DPM for the event "SAP Prepared" in Figure 1-2:

"The project coordinator, using the TCP created in the requirements development process, in consultation with the laboratory staff, prepares an SAP." The participants (and their relations to the event) are the project coordinator ("do"), the laboratory staff ("do"), the TCP ("use"), and the SAP ("produce"). The event "SAP Prepared" cannot occur until the TCP is available from the "Sampling Requirements Defined" event (precedence). 
Figure 1-1. Modeling Constructs.

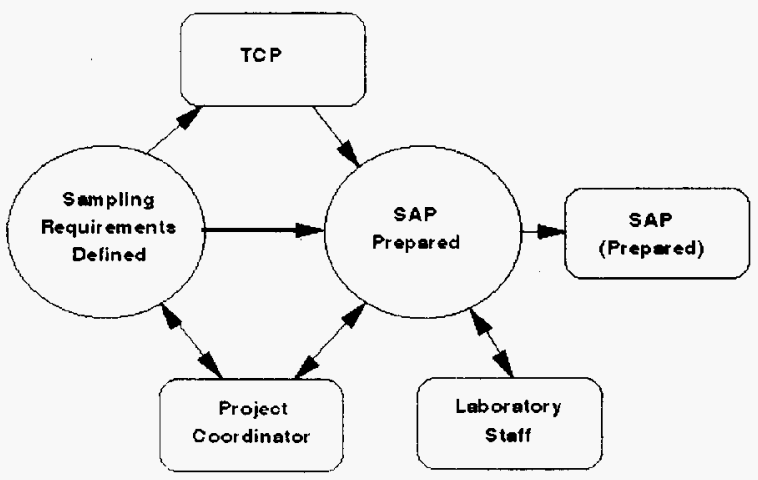

SAP $=$ Sampling and Analysis Plan

TCP $=$ Tank Characterization Plan

Figure 1-2. Sample Dynamic Process Model.

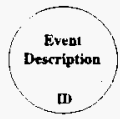

An event represents the completion of an activity or process

An event is teptesented by a circle defined with a description and an identifier

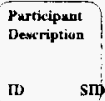

A participant is a type of physical or abstract object .

A participant is represent by a rounded rectangle (roundtangle) and defined with a description, an identifier (ID), and a state identifier (SID)

\section{Do Relationship}

The participant performs, facilitates, controls, or manages the process represented by the event

- Use Relationship

The participant is "used" by the process

Change Relationship

Participant is "changed" by the process 


\subsubsection{ORM}

The ORM depicts the relationships among the participants, as objects, within the model. The object relationships represented within the model include some or all of the following:

- is a - A specialization relationship ("is a") is a relationship between two object types which indicates that the instances of one type constitute a sub-set of the instances of the other. Specialization is the grouping of objects based on the sharing of common features; the first object inherits characteristics from the second, and answers questions about how the two object types are similar.

- part of - A composition relationship ("part of") is a relationship between two object types which represents the assembly of a complex (composite) object from other objects. Composite relationships answer questions about how things are assembled. The composite object type retains the qualities of the parts, and possesses emergent properties which are not properties of any of the parts. Each constituent object type is mandatory for the composite object to retain its fundamental character and its ability to perform its intended function.

- contained in - An inclusion relationship ("contained in") is a relationship between two object types which defines the composition of an object type in terms of other object types. Inclusive relationships represent coupling; each constituent type is not required for the containing object to retain its fundamental character and its ability to perform its intended function.

- changes ro - A transformation relationship ("changes to") specifies that instances of the first participant in the relationship are used in the activity which creates instances of the second participant. The event involved creates new instances of the second participant, while using and consuming the instances of the first participant.

- becomes - A transition relationship ("becomes") is a relationship between the same participant in different states which specifies that instances of the participant in the first state can become instances of the participant in the second state through a state transition. Transition relationships specify the mapping between two states of a participant, and represent the sequence of state changes over time.

- association - A generic relationship that can be analyst specified; e.g., an application "creates" a display file, a robot "retrieves" waste. 


\subsection{CHARACTERIZATION}

\subsection{EXECUTIVE SUMMARY}

This section presents the results of an analysis performed to document the current or As-Is processes used to characterize tank wastes. The analysis was performed in two phases. Phase 1 focused on the TCR generation process and resulted in WHC-SD-WM-PD-045, Tank Waste Remediation System Information Systems Definition Tank Characterization Report Generation Process As-Is (Legore 1996). The goal of Phase 1 was to identify specific opportunities for improving the TCR process and shortening the time required to issue the document. Phase 2, documented in this report, adds details about other key characterization areas while retaining the information developed in Phase 1.

\subsubsection{Overview}

A key part of the overall effort to control the hazards associated with waste management is a better understanding of the waste characteristics. This is the objective of tank waste characterization. Knowledge of the waste properties is necessary to plan and safely conduct operations involving storage, retrieval, processing, and disposal. Users of characterization information include RL, other stakeholders, outside oversight bodies such as the Defense Nuclear Facilities Safety Board (DNFSB), and most of the TWRS organizations.

The characterization process begins with an assessment of information derived from historical data, ongoing surveillance information, and prior analyses of other tanks where the wastes contained are thought to be similar. In most cases, however, additional data must be collected by other means that generally involve the use of intrusive sampling techniques. The resources needed to perform this sampling are costly and the operations are potentially hazardous, so great care and detailed planning are required to successfully and safely optimize the information obtained from each sampling and analysis event.

Several key documents are prepared to support the various phases of characterization. The processes that produce them are the primary subjects of this report. These processes include DQOs, tank waste analysis plans (TWAP), tank characterization plans (TCP), sampling and analysis plans (SAP), analysis data packages, and TCRs.

Tank characterization reports are viewed as the ultimate product of the characterization process. They designed to be a single source document for all information regarding an individual tank, including physical structure, operational history, sampling history, sample analysis data. waste content estimates, current status, and recommendations for future data collection activities. Ultimately, each of the $177 \mathrm{HLW}$ tanks will have a corresponding TCR. Currently, TCRs have been published for more than 58 tanks. 
A TCR is prepared (or revised) as a result of each sampling event for each tank. Westinghouse Hanford Company has established an internal requirement that TCRs are to be published within 90 calendar days of the issuance of the final data report which documents the laboratory analysis results of the samples obtained from the tank. Each TCR is, by necessity, a snapshot in time of the interpreted tank conditions.

\subsubsection{Significant Problems/Gaps}

The major problems and gaps that appear in the processes studied are as follows.

- Waste characterization is viewed and managed as a single large process instead of smaller (more manageable) subprocesses. The large process approach requires unique expertise and knowledge of individuals such as project coordinators to ensure successful completion and dissemination of information. This philosophy does not permit the development of a "corporate memory," i.e., accumulation of lessons learned and an easy transfer mechanism to new employees. This also does not appear to provide sufficient structure to support the current DOE philosophy of a Management and Integration Contractor outsourcing work to subcontractors.

- The use of Basic Ordering Agreements (BOA) as the mechanism to subcontract work fosters an unstructured relationship between the Characterization organization and the subcontractor. Enforcement of standards and imposition of process requirements through this contracting structure are time-consuming negotiation processes and not easily done.

- There is a lack of data traceability. Discrepancies between the TCRs and the Tank Characterization Database (TCD) are an ongoing problem. The TCD is not currently used by the project coordinators.

- Internal standards for work quality are not consistently applied. Performance and quality of work depend on the expertise of each individual with minimal coordination across the organization. Standards are needed for document content and formats, methods for calculations, and repetitive judgments, e.g., sample validity and representativeness.

- There is a large amount of decentralized effort currently underway to improve the characterization process. The ongoing change efforts need to be brought under, at least, limited control. 


\subsubsection{Next Steps/Recommendations}

The next steps should be as follows.

- Bring the ongoing change efforts under limited control.

- Examine the process recommendations given in Section 2.1.2.

- Map these recommendations against the current ongoing process improvements.

- Construct an interim priority listing of activities based on precedence and compatibility of efforts.

Current efforts that require the completion of other improvements to be effective should be slowed or stopped, while those activities that can be independently implemented and are compatible with the As-Is findings allowed to continue.

\section{$2.2 \mathrm{DPM}$}

The DPM, Figures 2-1 through 2-10, shows the main events, participants, and products of the Waste Tank Characterization program. The characterization process consists of the following sub-events:

- DQOs Developed

- Sampling Requirements Developed

- SAP Developed

- Field Instructions Developed

- Samples Collected

- Samples Analyzed

- TCD Updated

- Data Packages Issued

- TCR Issued

- Anomalous Data Reviewed.

These events are performed at least once and may be repeated, as necessary, for each tank. The first pass results in a new TCR. Subsequent passes result in revisions of the current TCR. Additional sampling events may be done to enhance knowledge about the tank or determine if changes in previously analyzed contents have occurred.

The models for two sub-events, "DQOs Developed" and Samples Analyzed," were quite large and could not fit easily into document format. These models are subdivided into multiple pages. Each of these is preceded by an "event only" view to assist in tracking the flow events through the entire multi-page model. 
WHC-SD-WM-PD-048 REV 0

Figure 2-1. Tanks Characterized Event Dynamic Process Model.

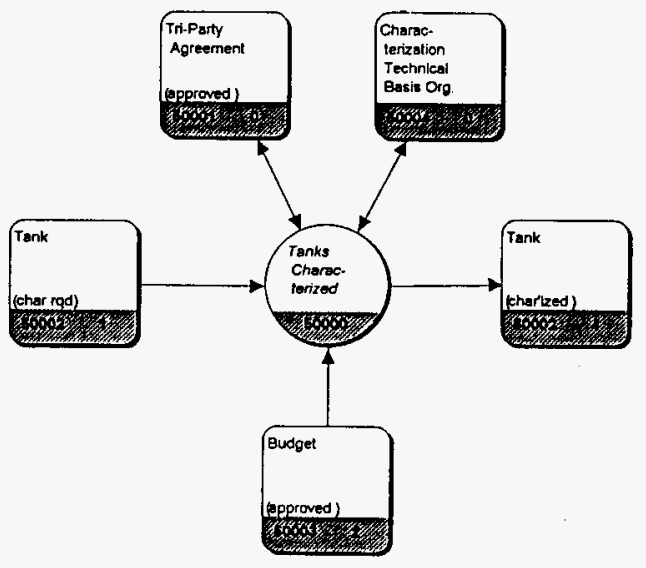




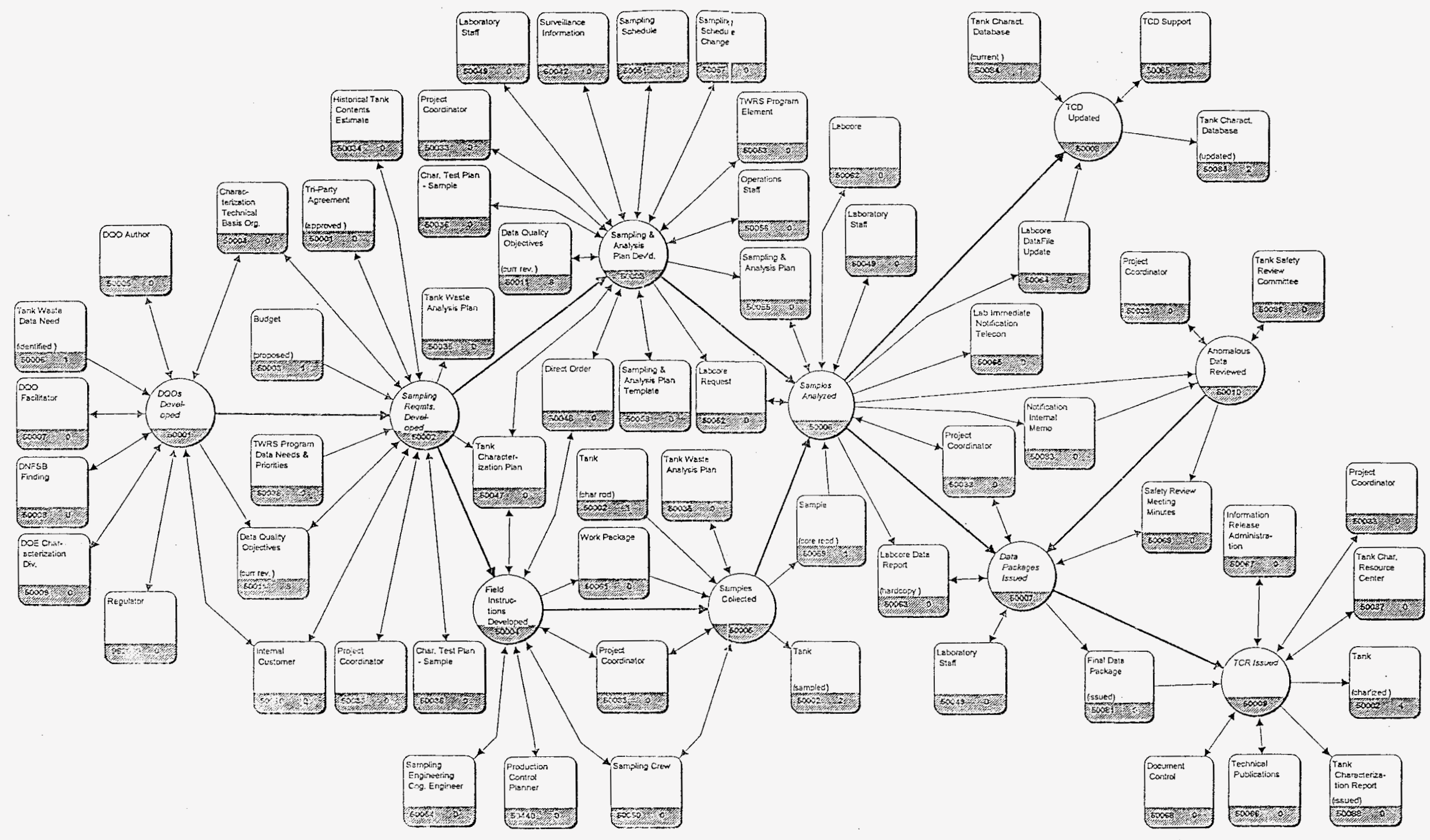




\section{WHC-SD-WM-PD-048 REV 0}

Figure 2-3. Data Quality Objectives Developed Dynamic Process Model - Sub-Event Flow.

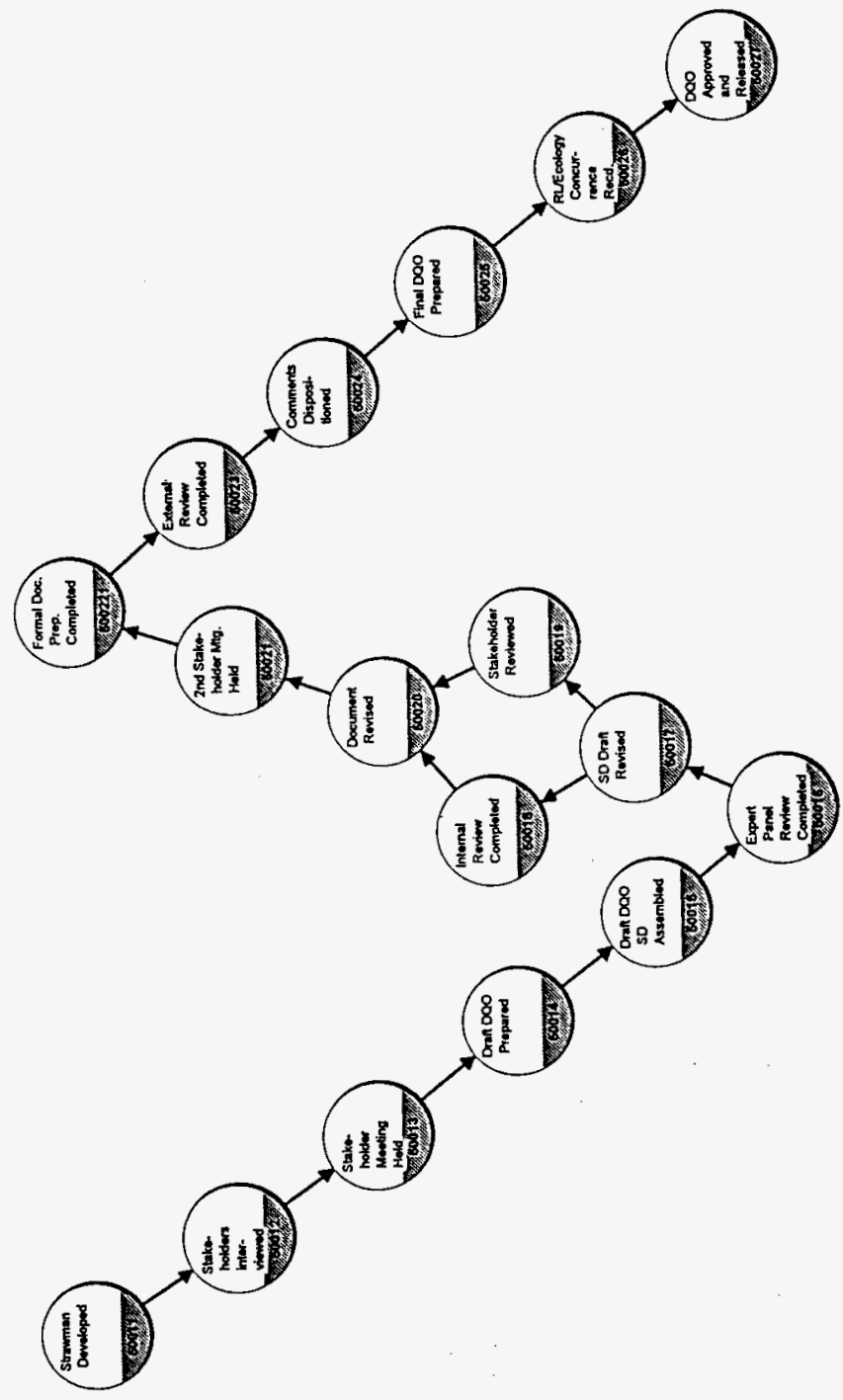


Figure 2-4. Data Quality Objectives Developed - Sub-Events. (5 sheets)

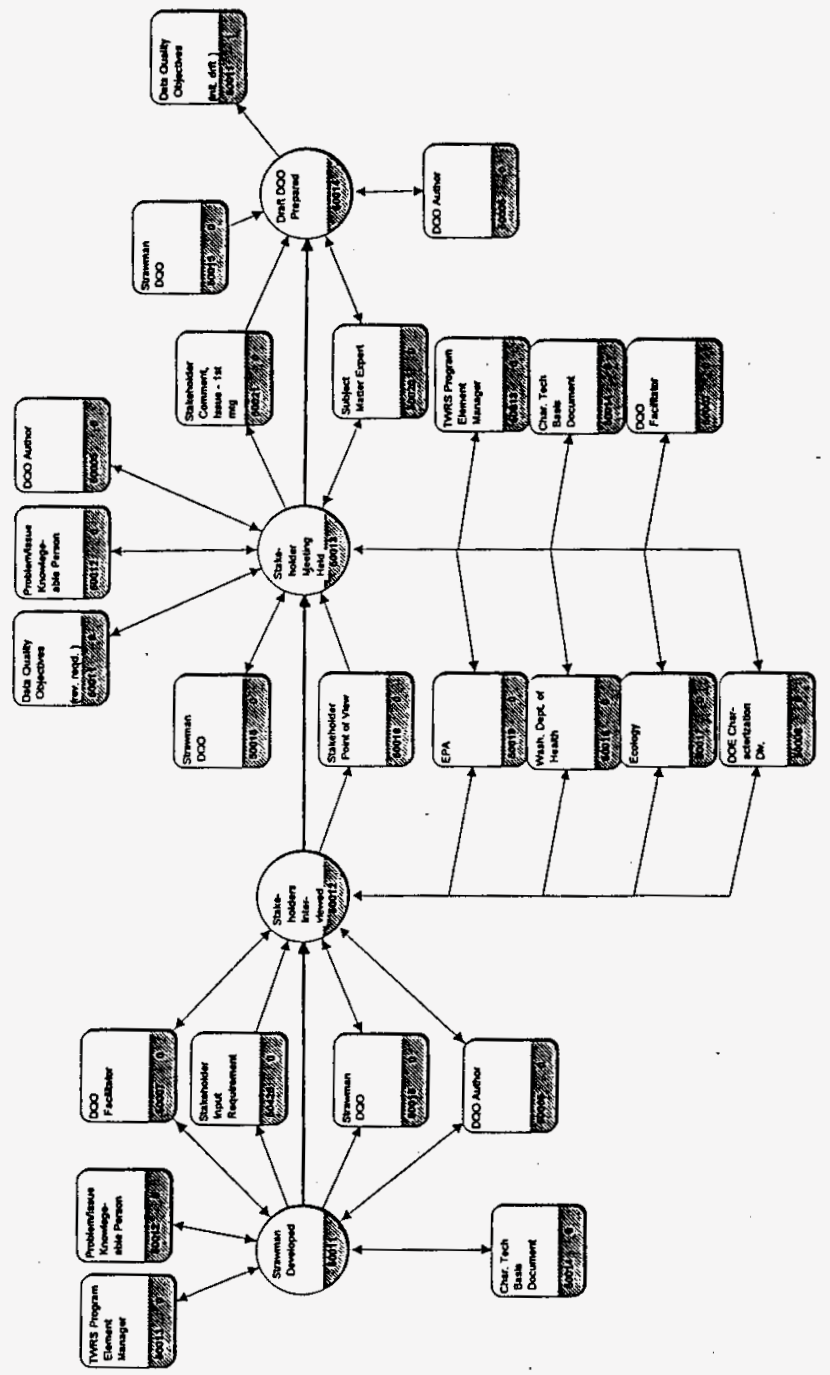


Figure 2-4. Data Quality Objectives Developed - Sub-Events. (5 sheets)

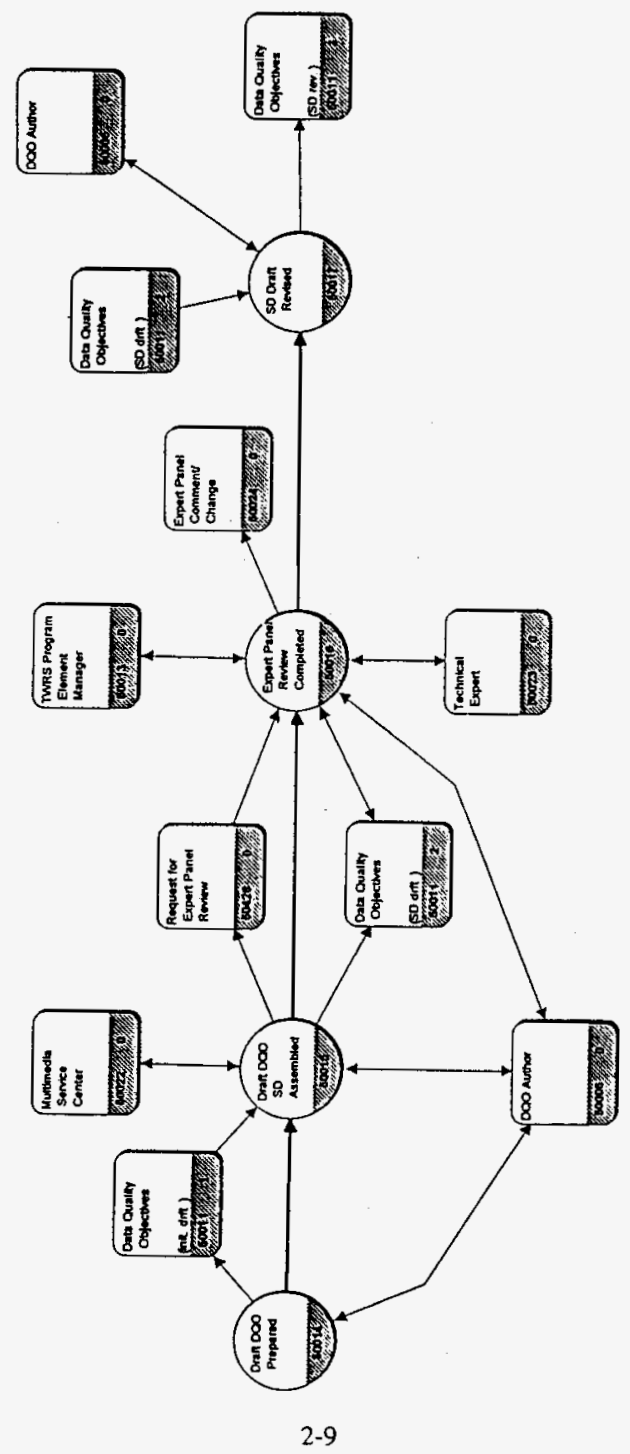


WHC-SD-WM-PD-048 REV 0

Figure 2-4. Data Quality Objectives Developed - Sub-Events. (5 sheets)

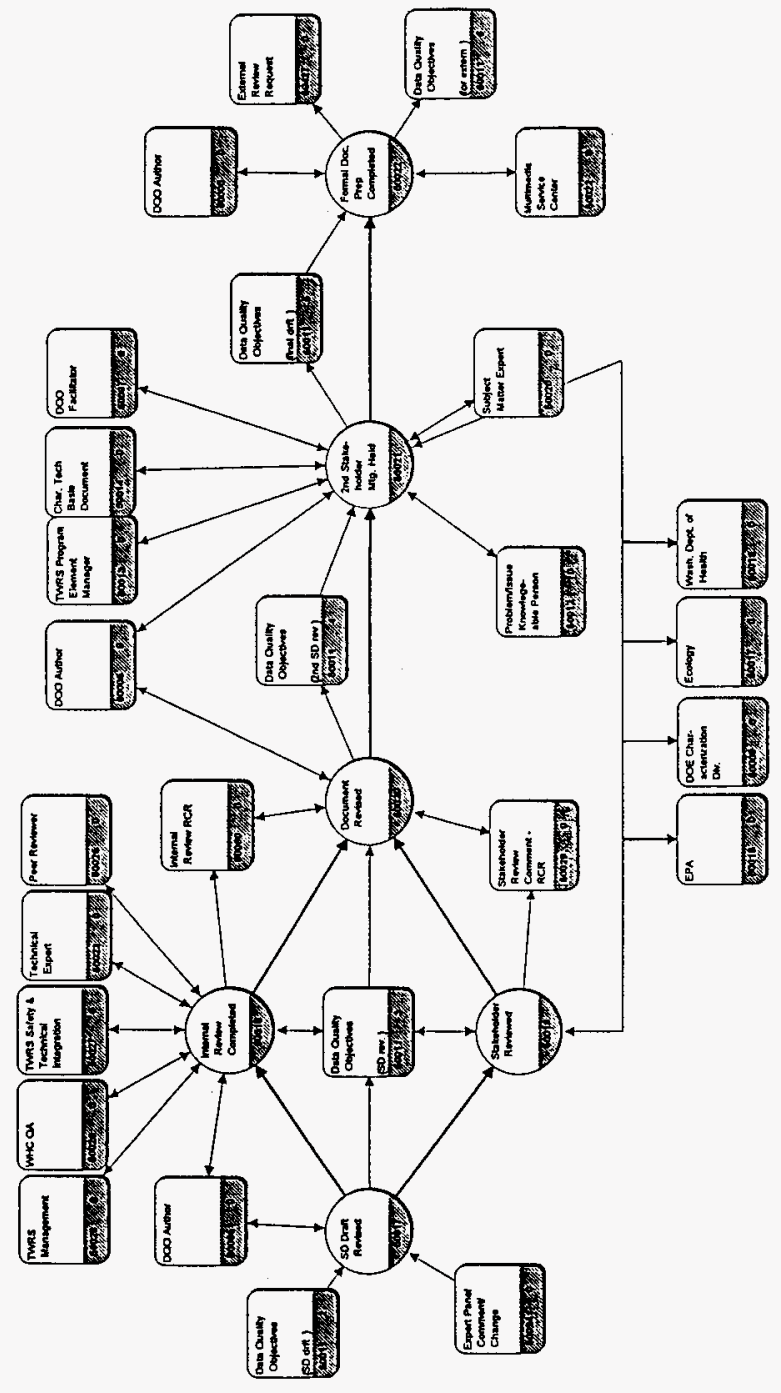


WHC-SD-WM-PD-048 REV 0

Figure 2-4. Data Quality Objectives Developed - Sub-Events. (5 sheets)

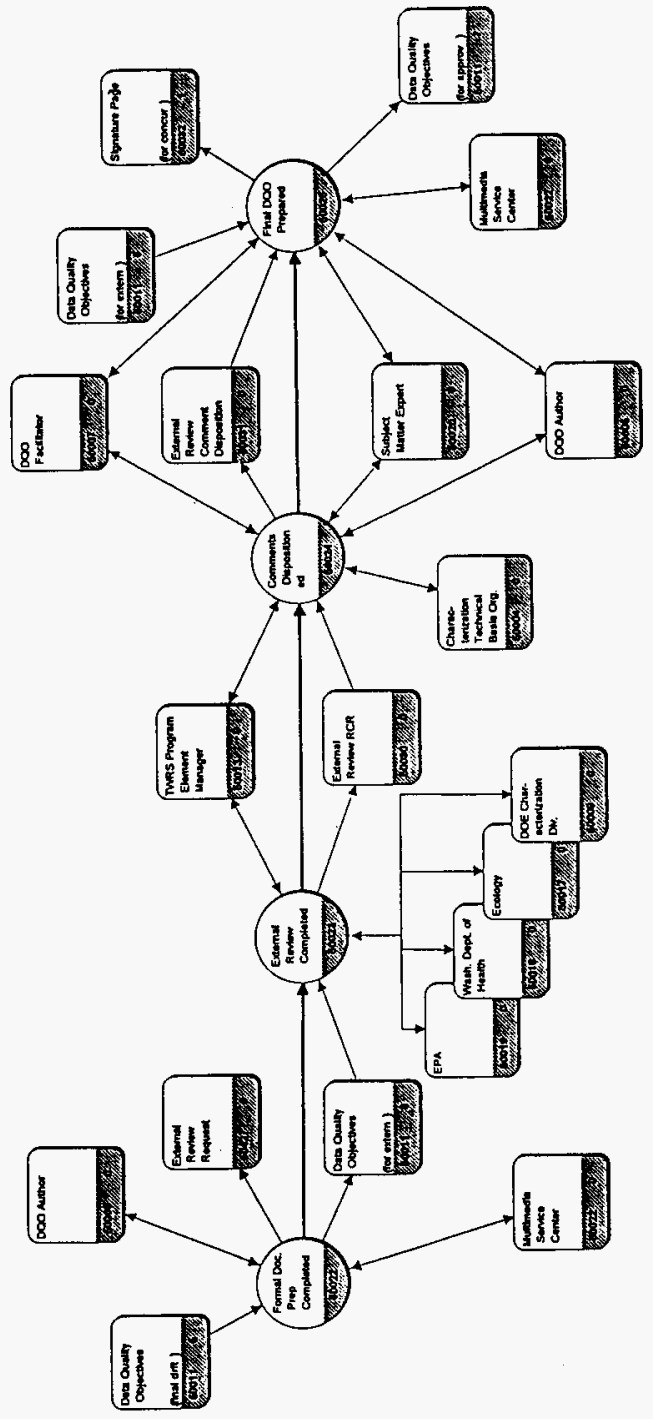


WHC-SD-WM-PD-048 REV 0

Figure 2-4. Data Quality Objectives Developed - Sub-Events. (5 sheets)

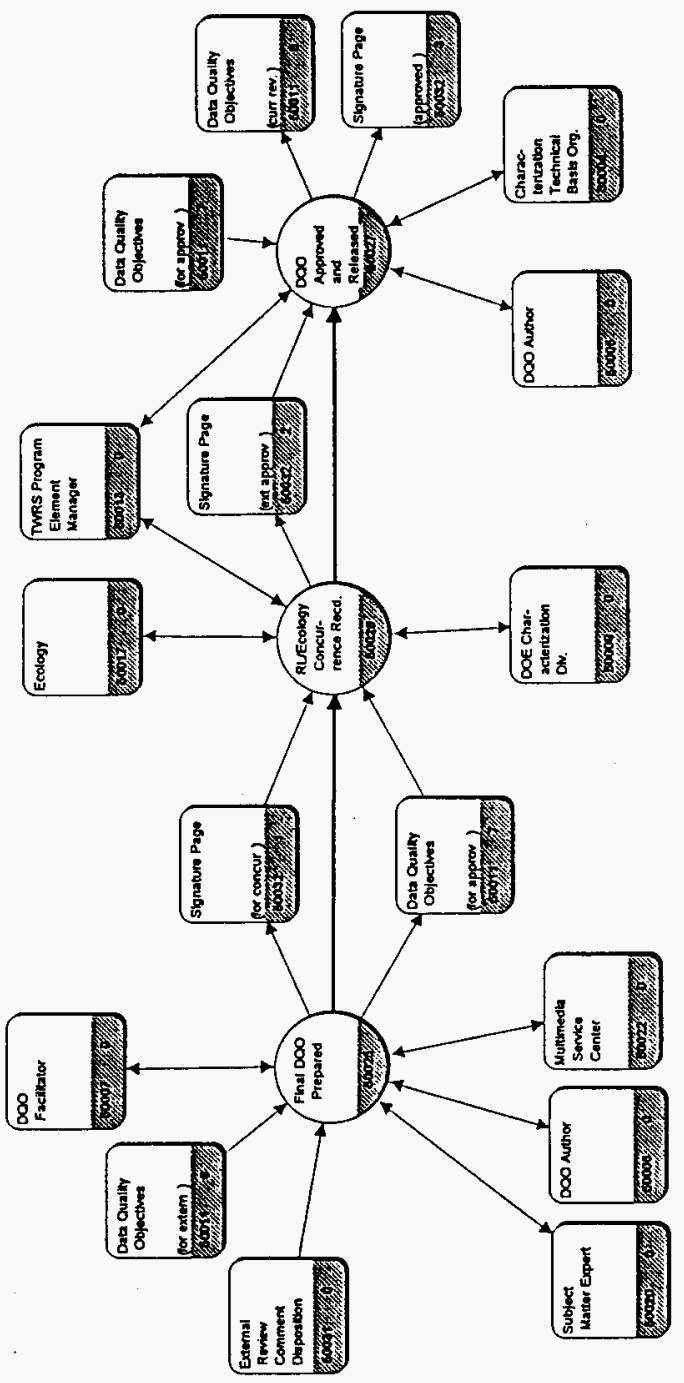




\section{WHC-SD-WM-PD-048 REV 0}

Figure 2-5. Sampling Requirements Developed - Sub-Event.

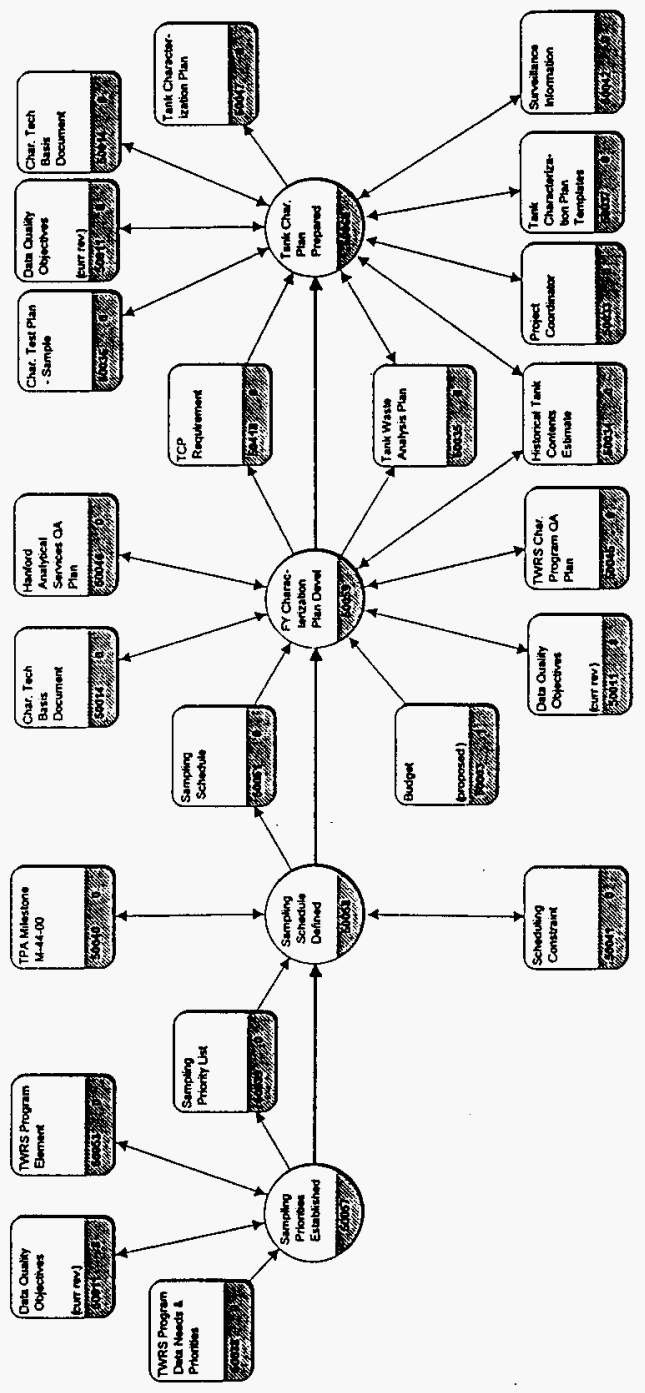


Figure 2-6. Samples Analyzed - Sub-Event Flow.

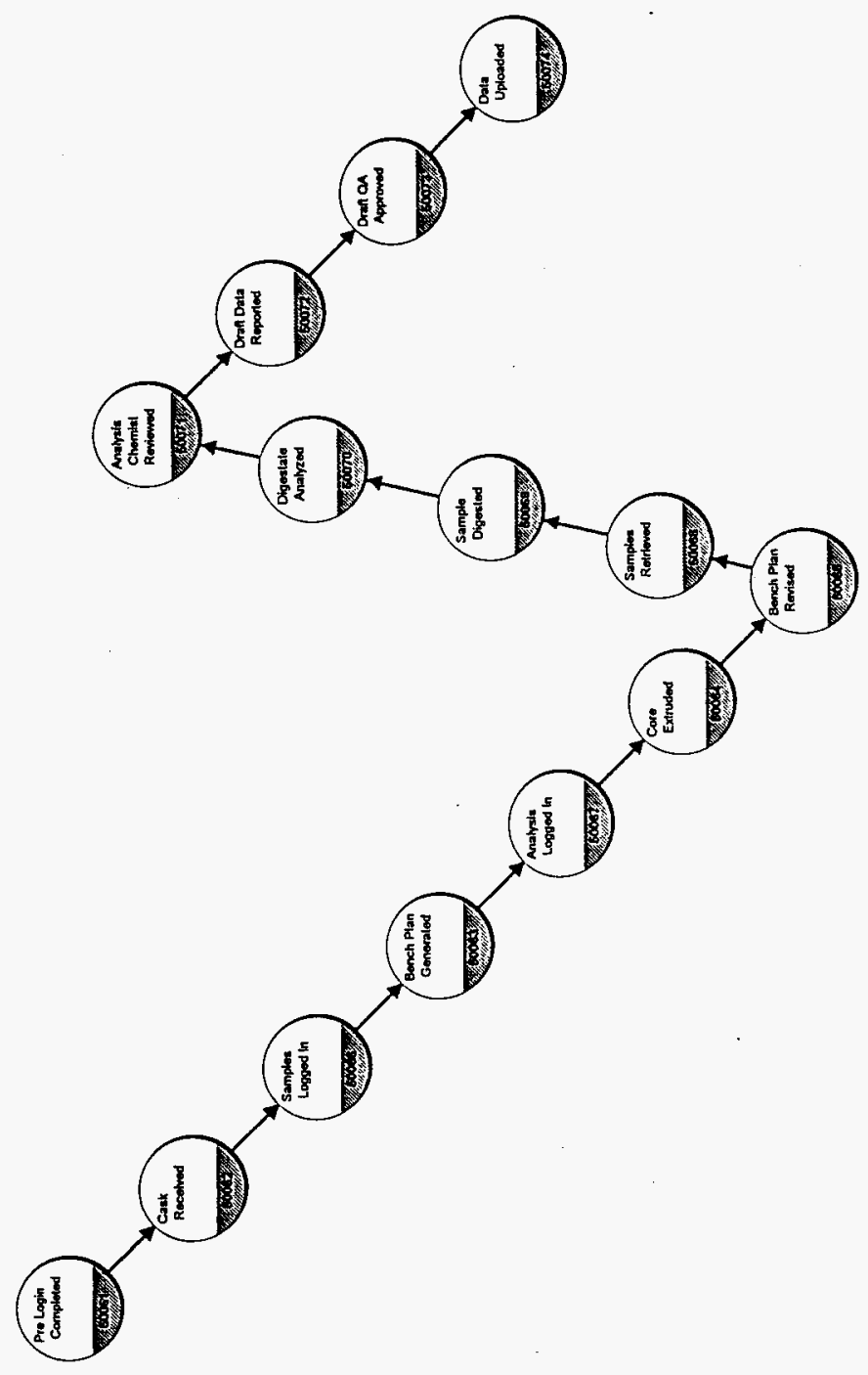


WHC-SD-WM-PD-048 REV 0

Figure 2-7. Samples Analyzed - Sub-Events. (3 sheets)

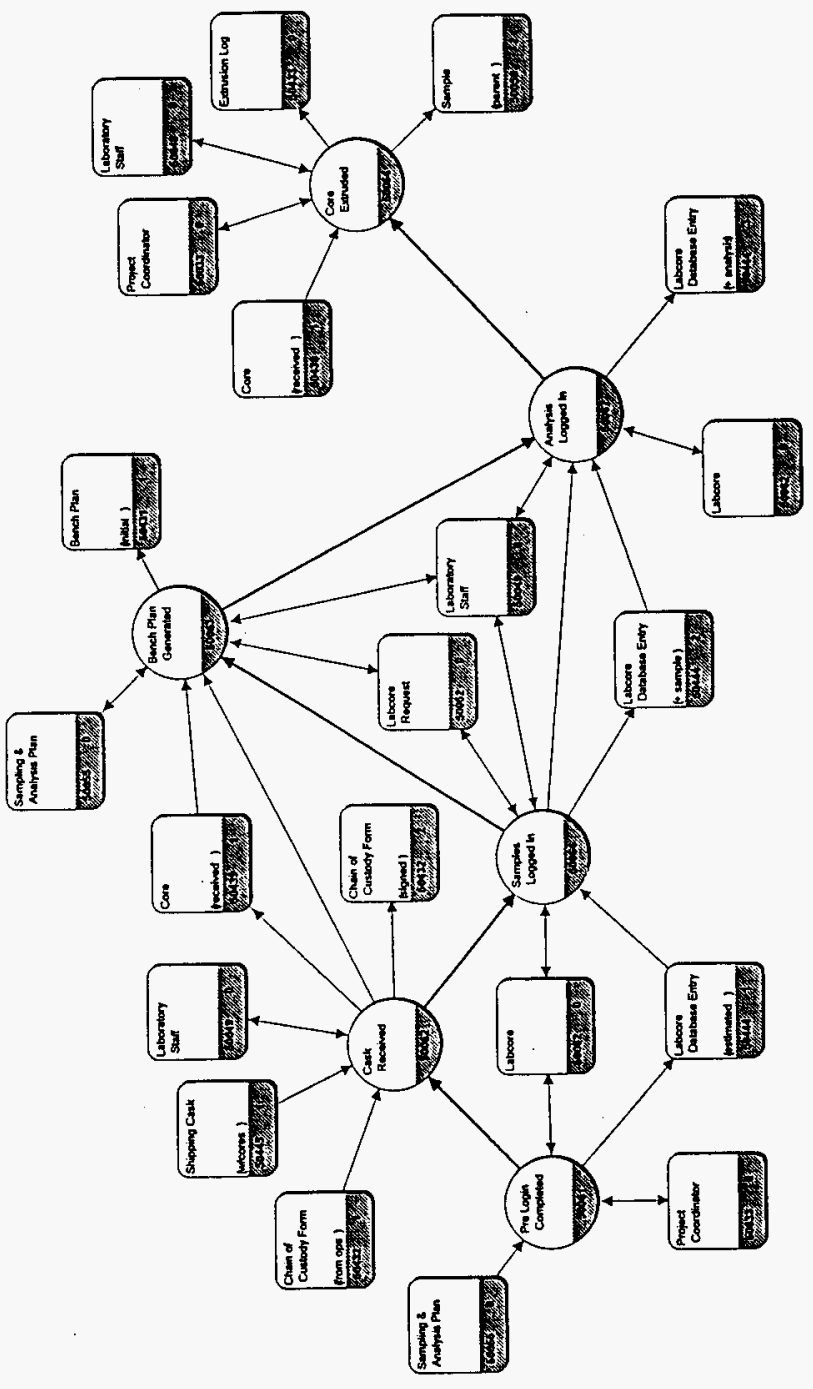


WHC-SD-WM-PD-048 REV 0

Figure 2-7. Samples Analyzed - Sub-Events. (3 sheets)

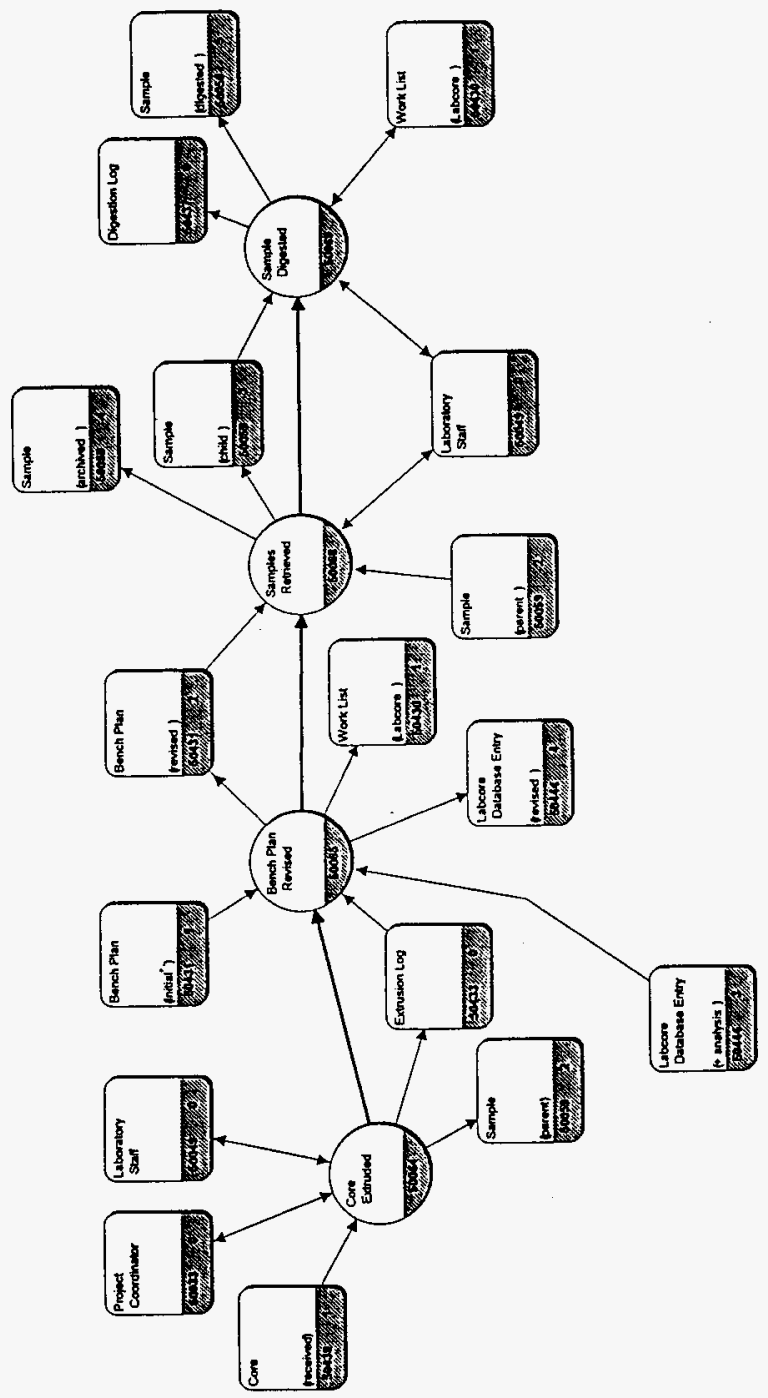


WHC-SD-WM-PD-048 REV 0

Figure 2-7. Samples Analyzed - Sub-Events. (3 sheets)

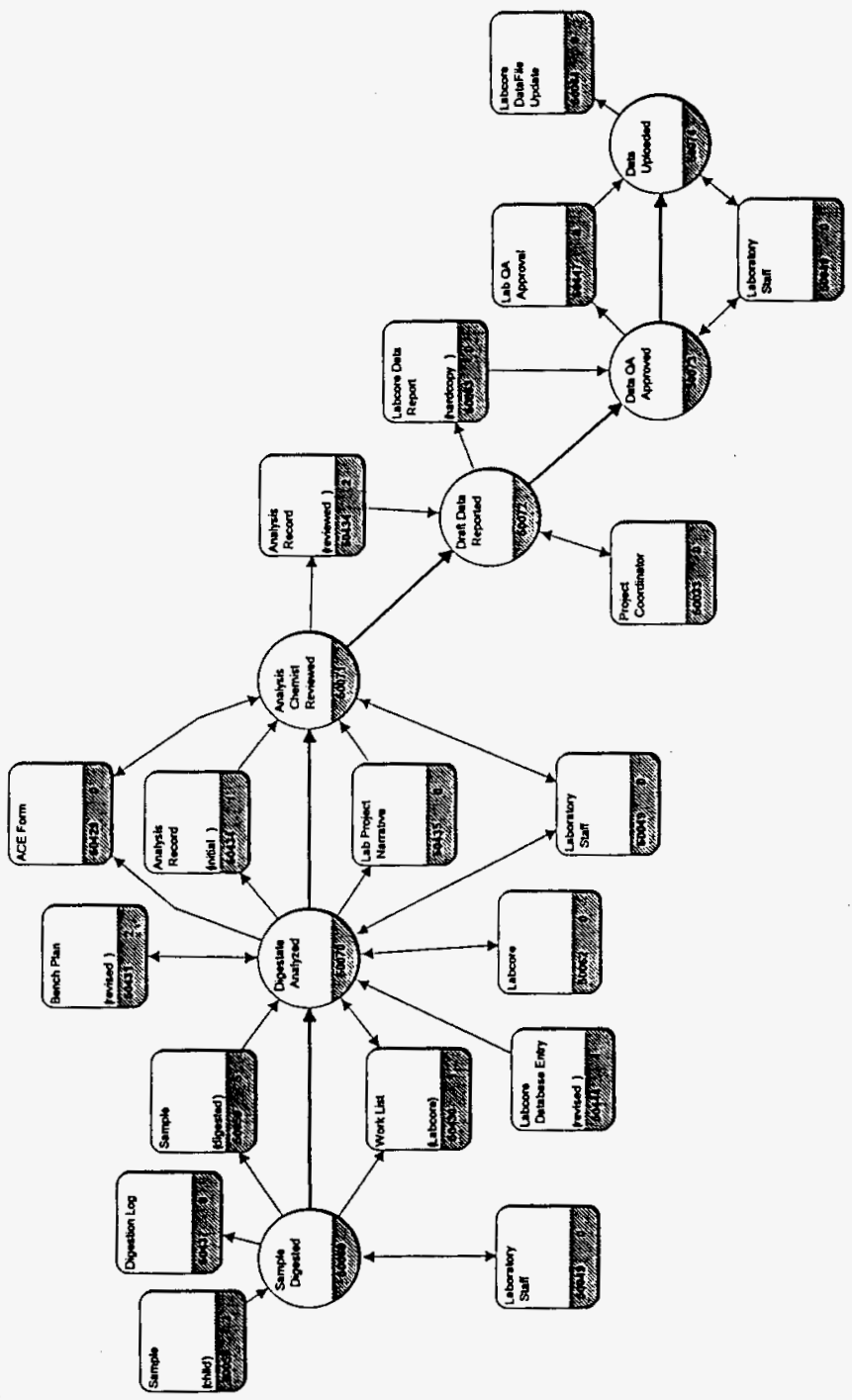


WHC-SD-WM-PD-048 REV 0

This page intentionally left blank. 


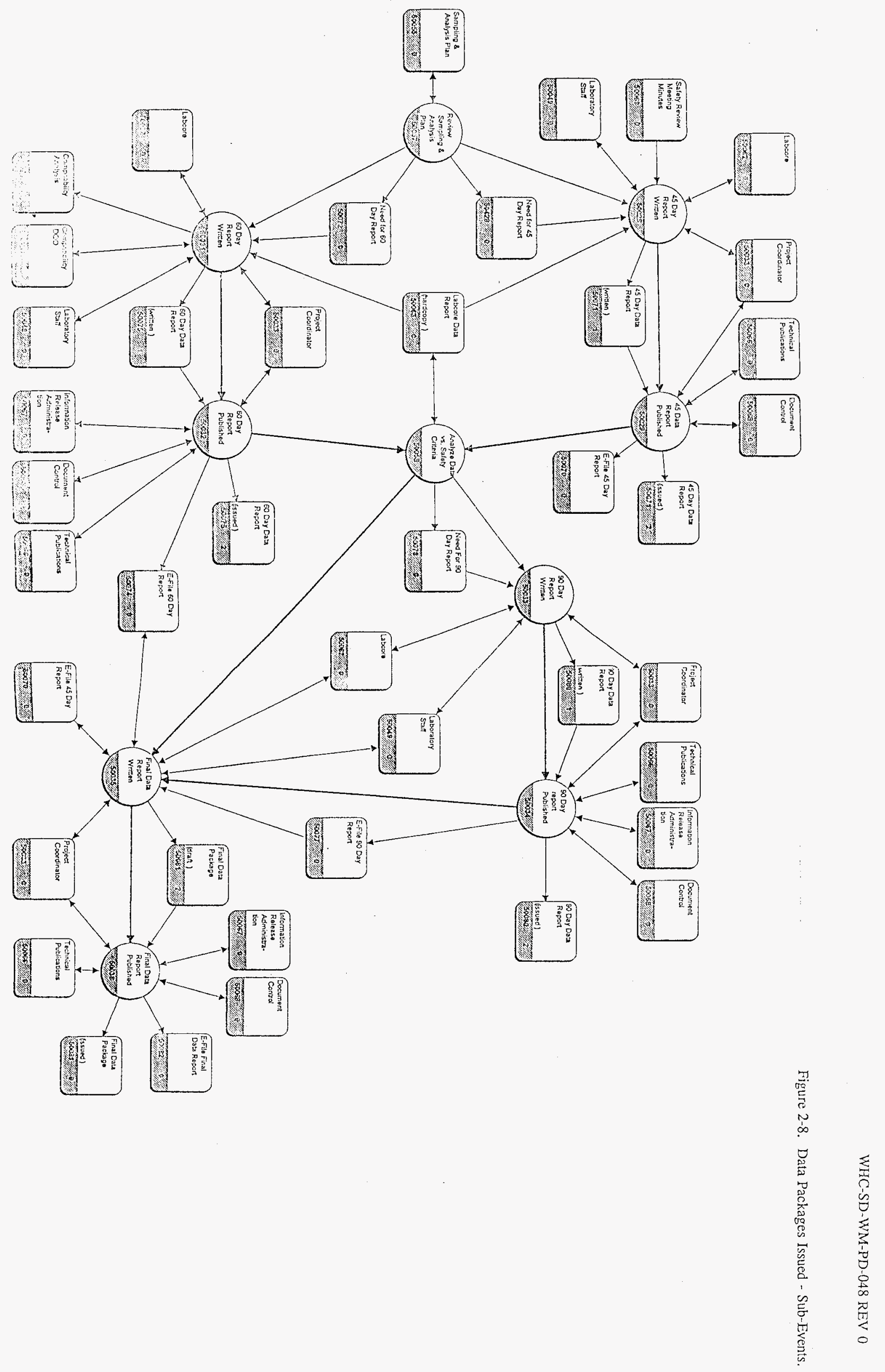


Figure 2-9. Tank Characterization Report Issued Sub-Events.

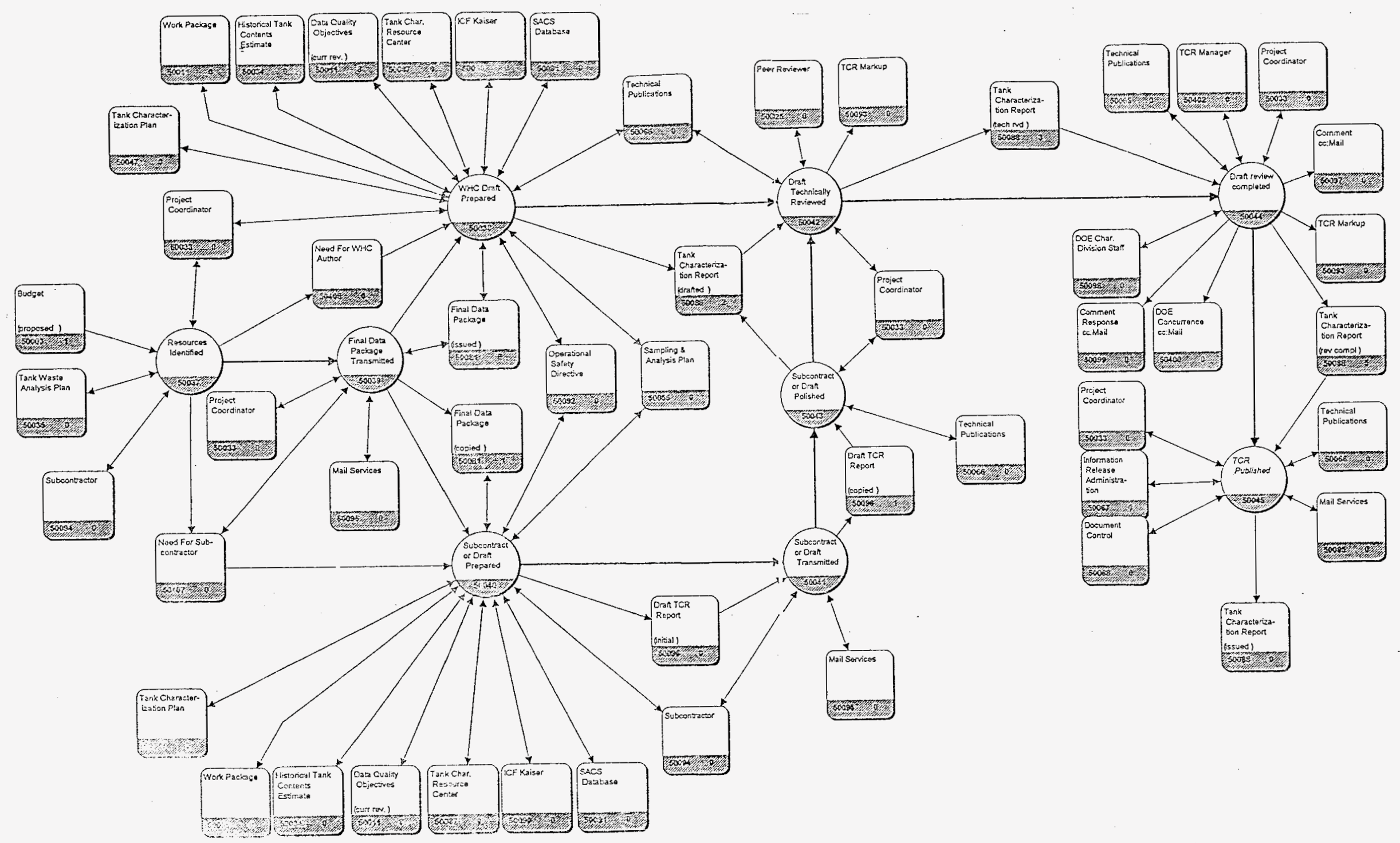


Figure 2-10. Tank Characterization Report Published - Sub-Events.

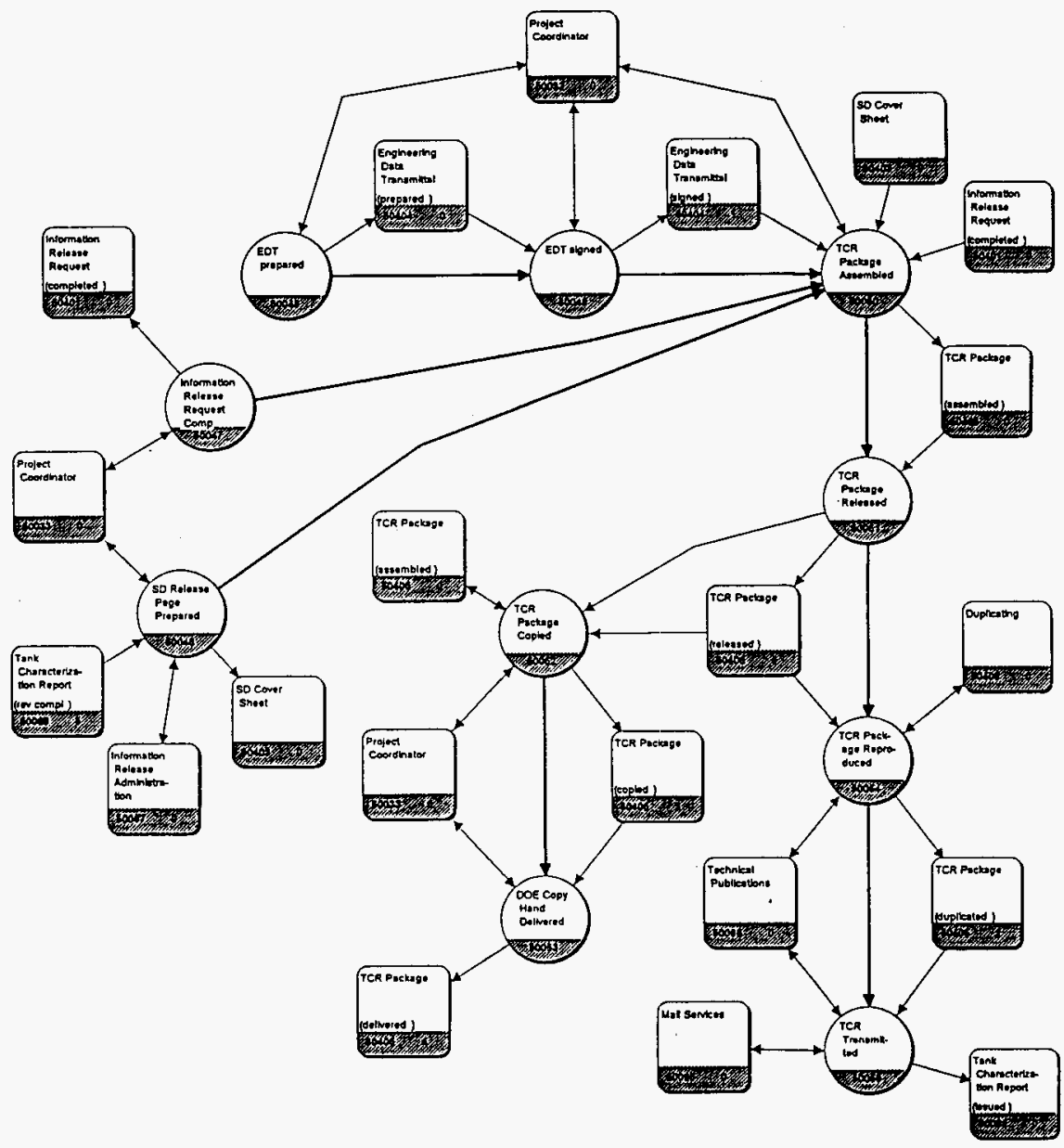




\subsection{ORM}

The ORM, contained in Figures 2-11 and 2-12, represents a different view of the participants in the DPMs. This model would normally be presented on one large sheet of paper, but for manageability it has been divided into blocks that will print on standard size paper. The first page (Figure 2-11) is an overview presentation that shows the top-level participants and allows the reader to locate the relative position of each sub-page in the model hierarchy.

\subsection{DPM DICTIONARY}

Table 2-1 contains definitions of the event objects found in the DPMs. The event names are arranged in alphabetical order and contain the event reference number from the models for reference. 
Figure 2-11. Object Relationship Model - Participant Overview.

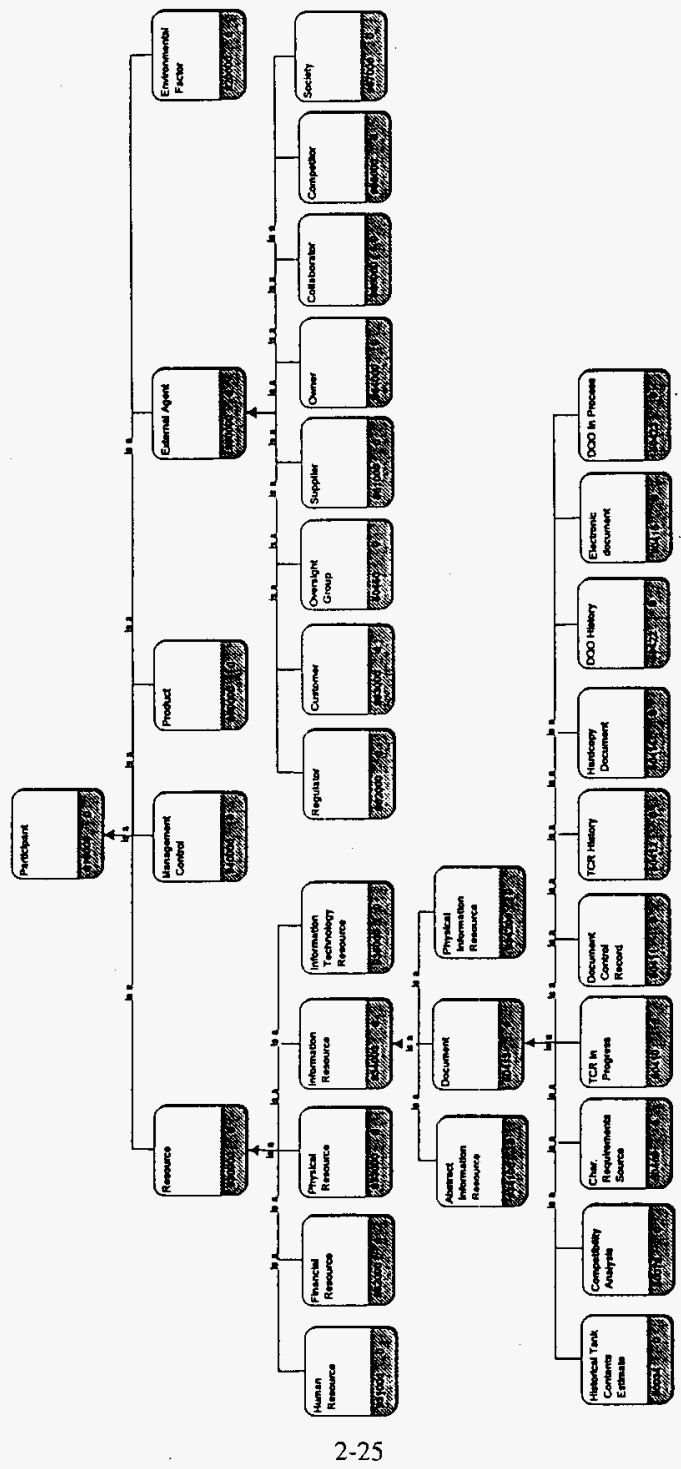


Figure 2-12. Object Relationship Model - Participant Detail. (13 sheets)

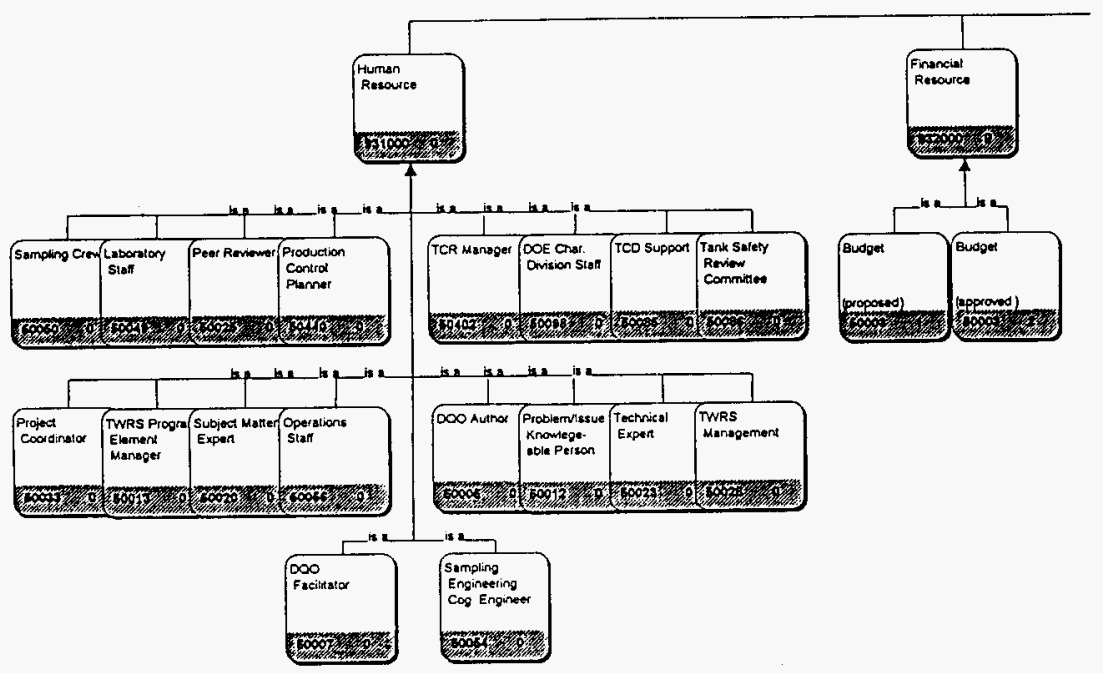


Figure 2-12. Object Relationship Model - Participant Detail. (13 sheets)

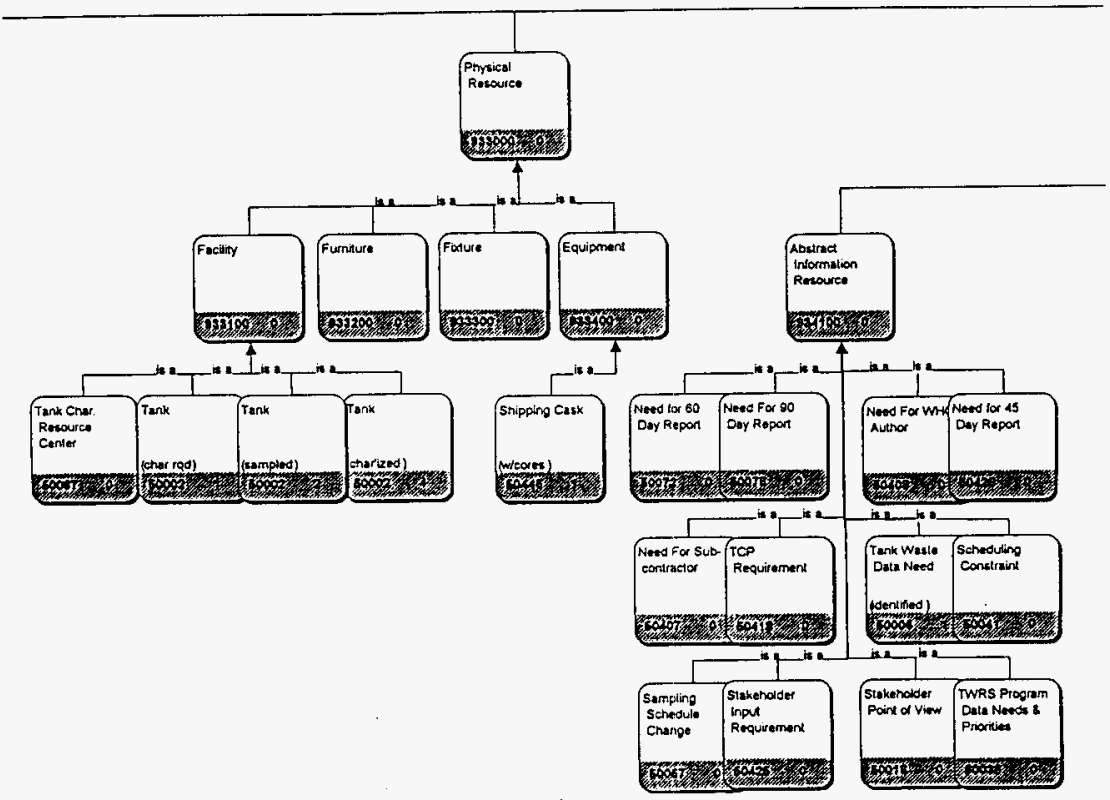


Figure 2-12. Object Relationship Model - Participant Detail. (13 sheets)

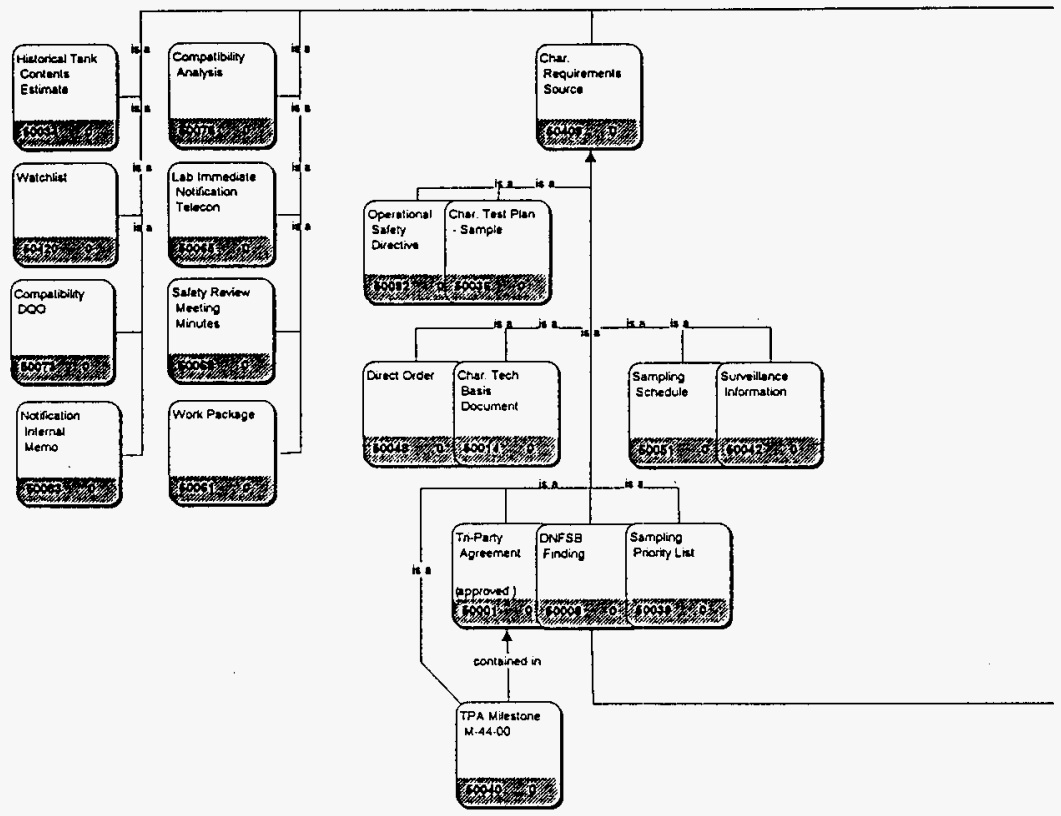


Figure 2-12. Object Relationship Model - Participant Detail. (13 sheets)

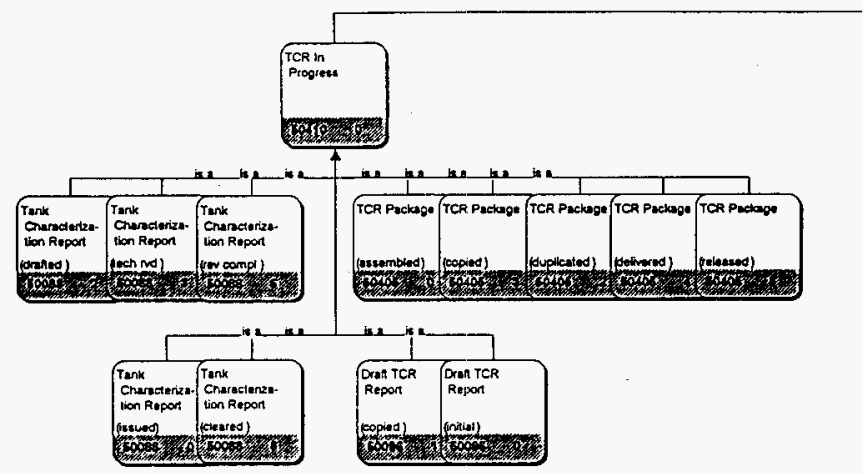


WHC-SD-WM-PD-048 REV 0

Figure 2-12. Object Relationship Model - Participant Detail. (13 sheets)

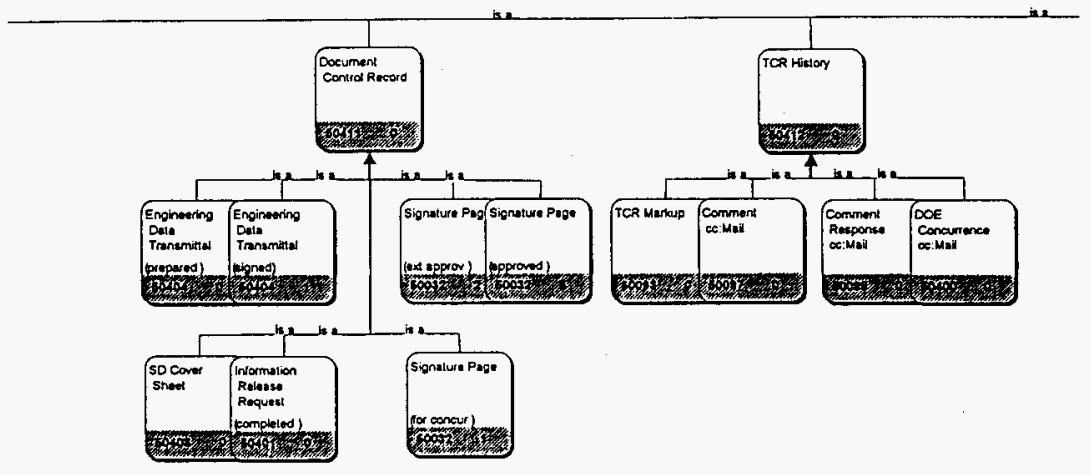


Figure 2-12. Object Relationship Model - Participant Detail. (13 sheets)

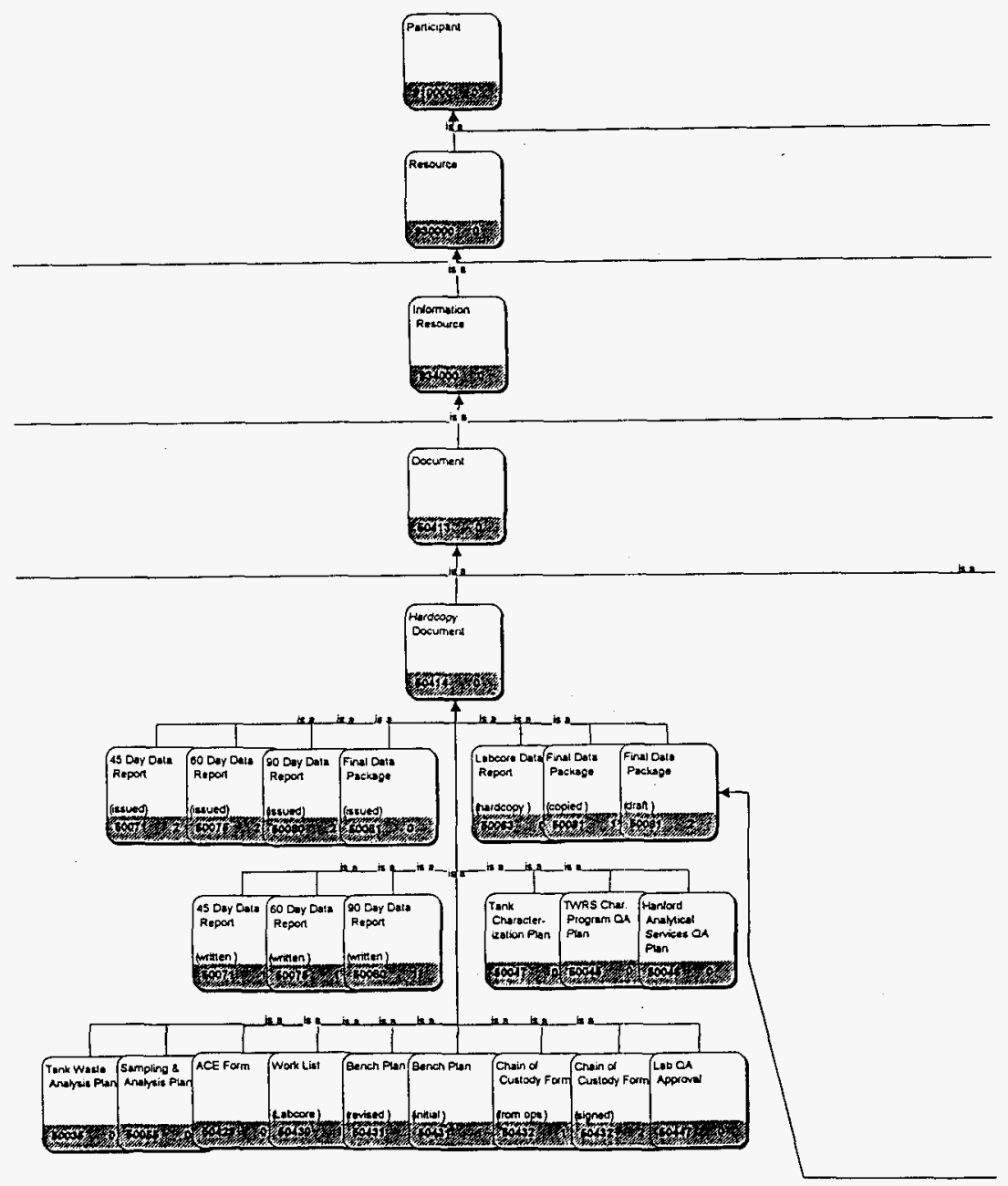


Figure 2-12. Object Relationship Model - Participant Detail. (13 sheets)

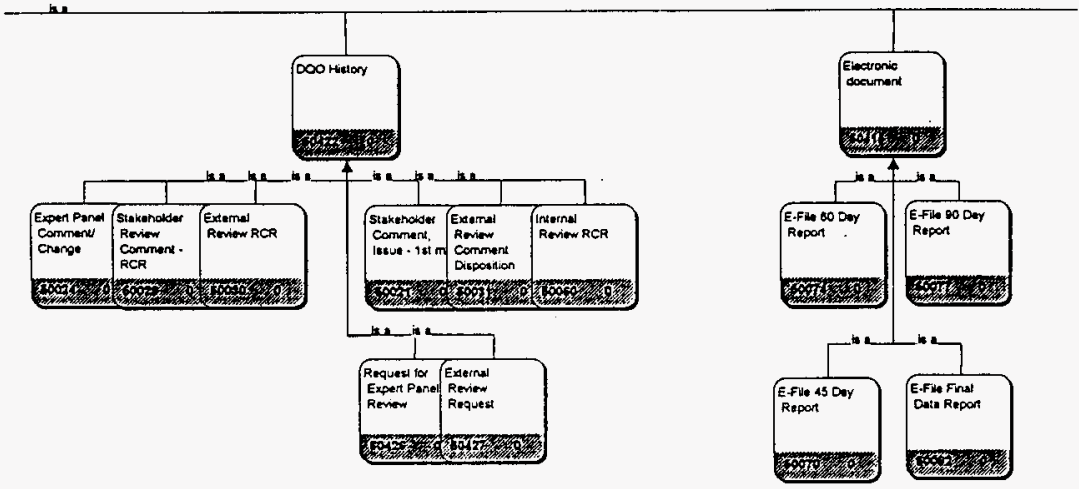


Figure 2-12. Object Relationship Model - Participant Detail. (13 sheets)

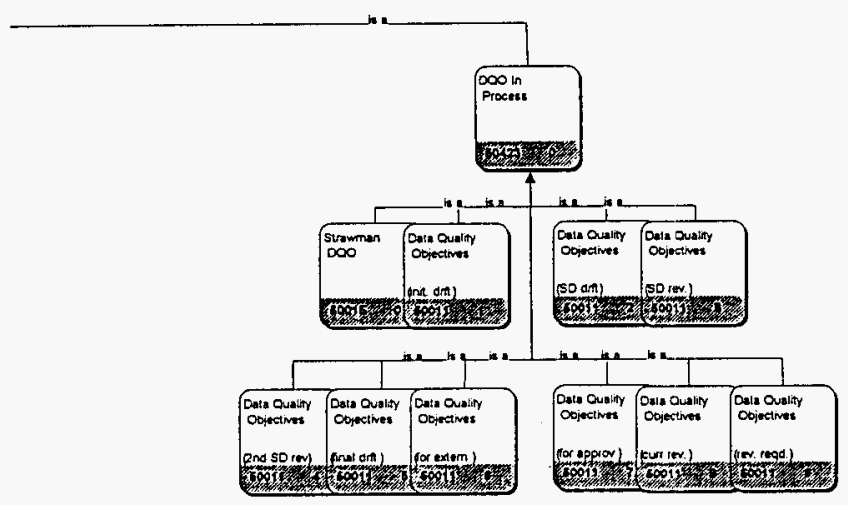


Figure 2-12. Object Relationship Model - Participant Detail. (13 sheets)

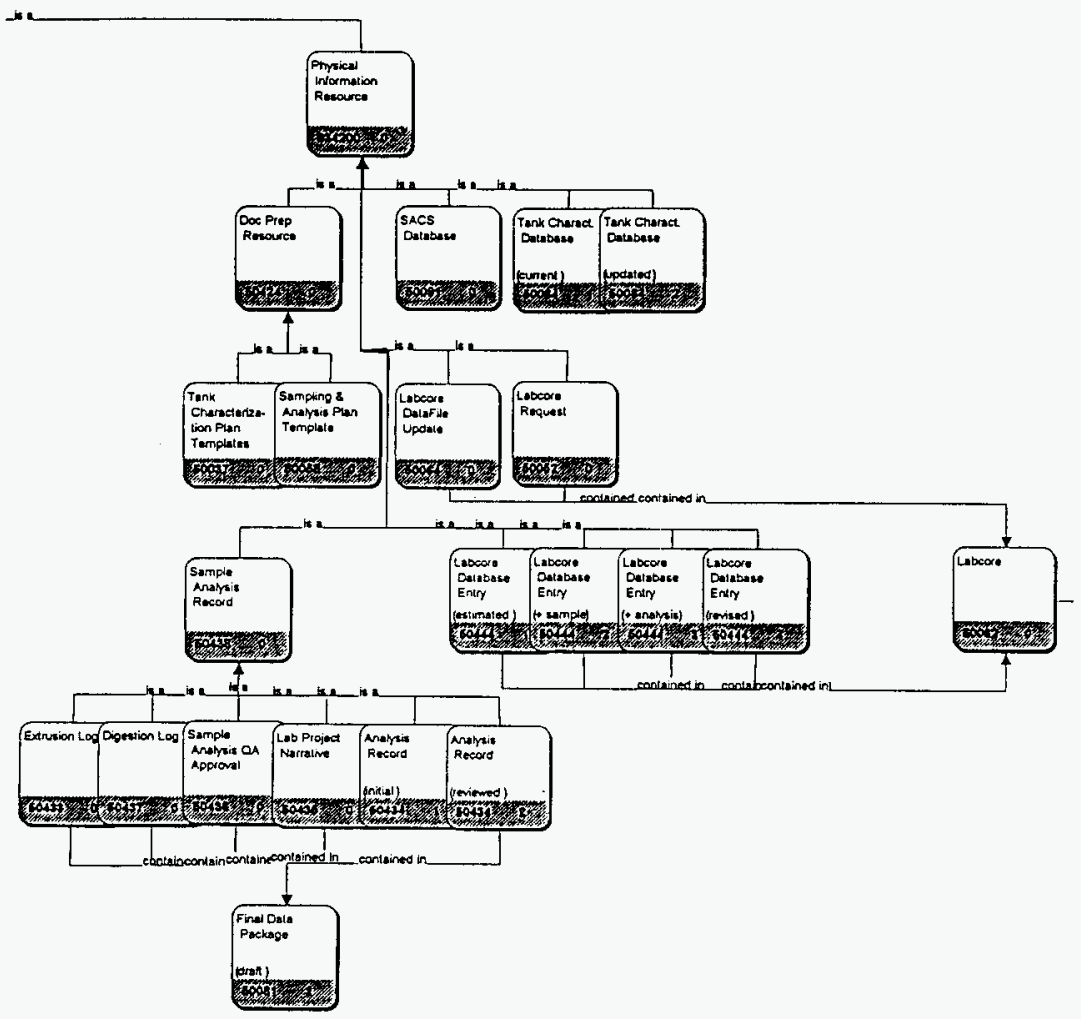


Figure 2-12. Object Relationship Model - Participant Detail. (13 sheets)

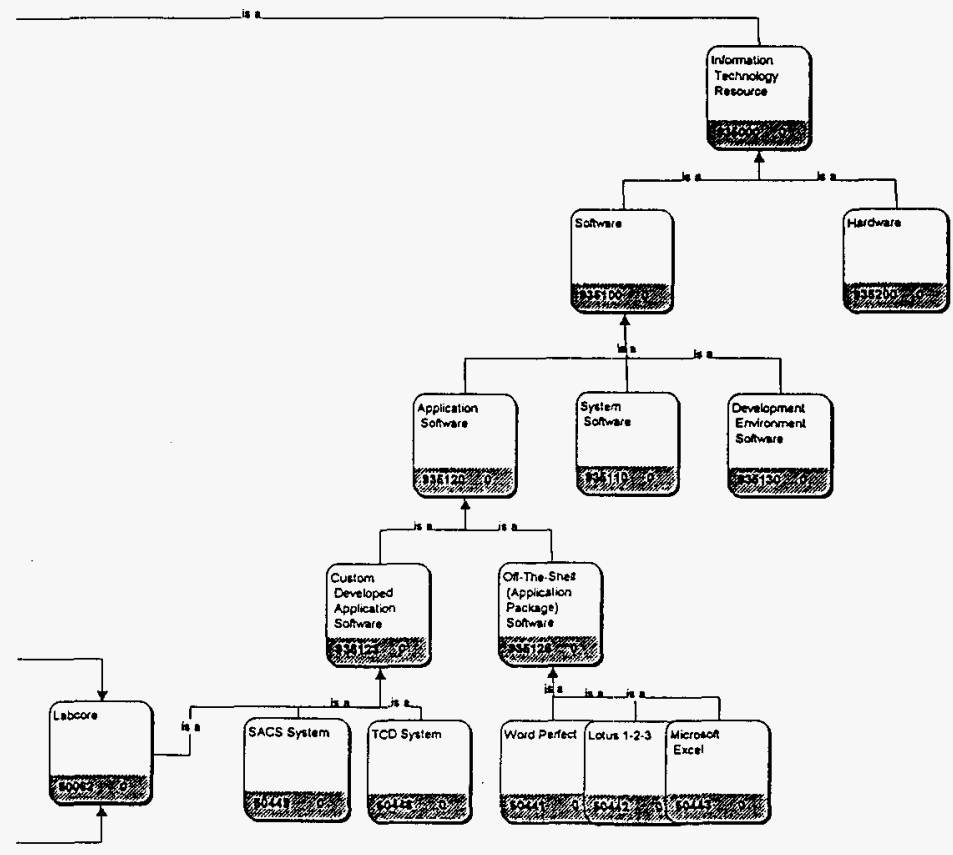


Figure 2-12. Object Relationship Model - Participant Detail. (13 sheets)

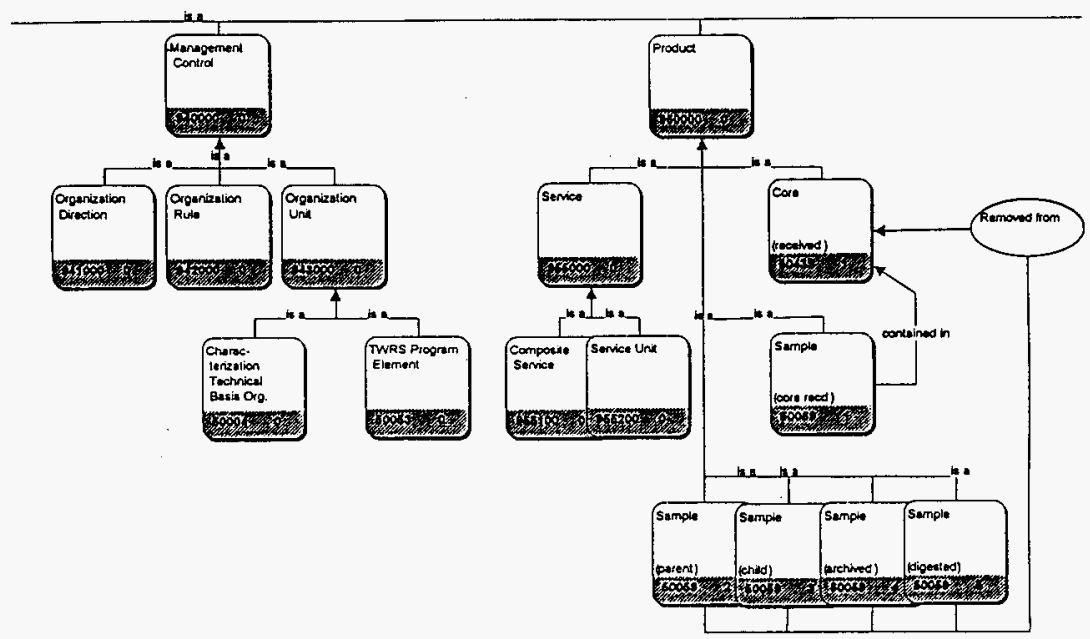


Figure 2-12. Object Relationship Model - Participant Detail. (13 sheets)

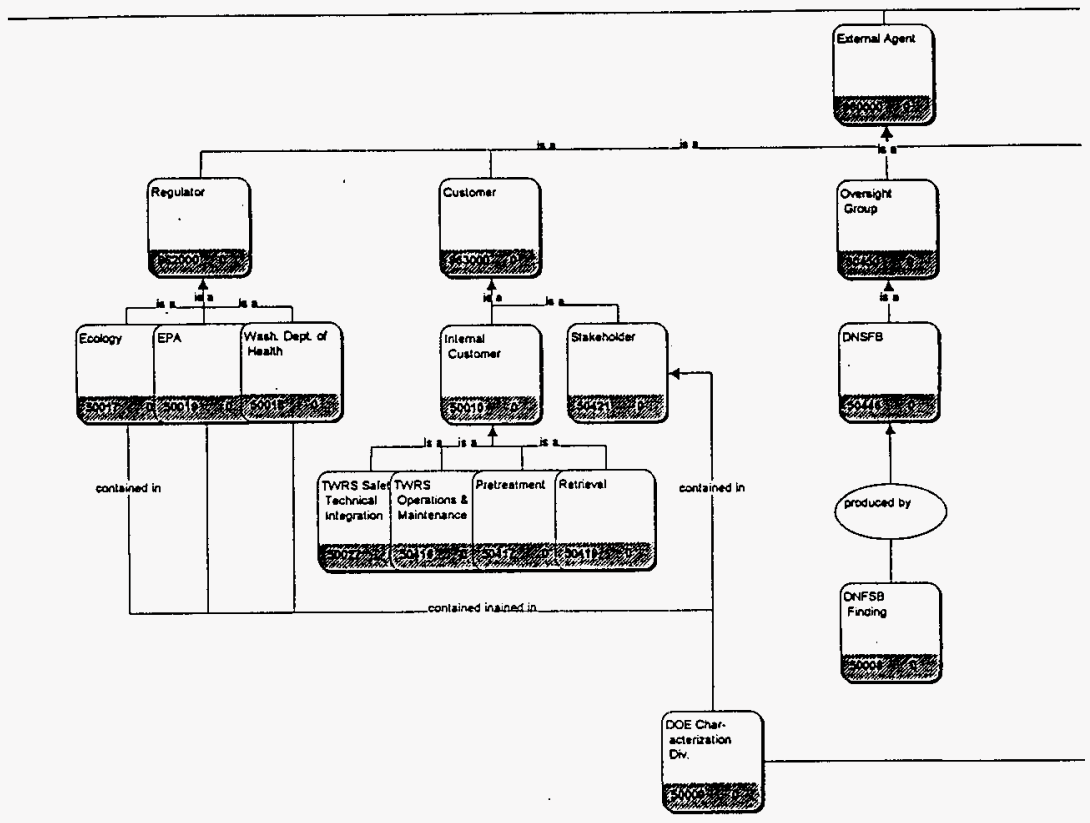


Figure 2-12. Object Relationship Model - Participant Detail. (13 sheets)

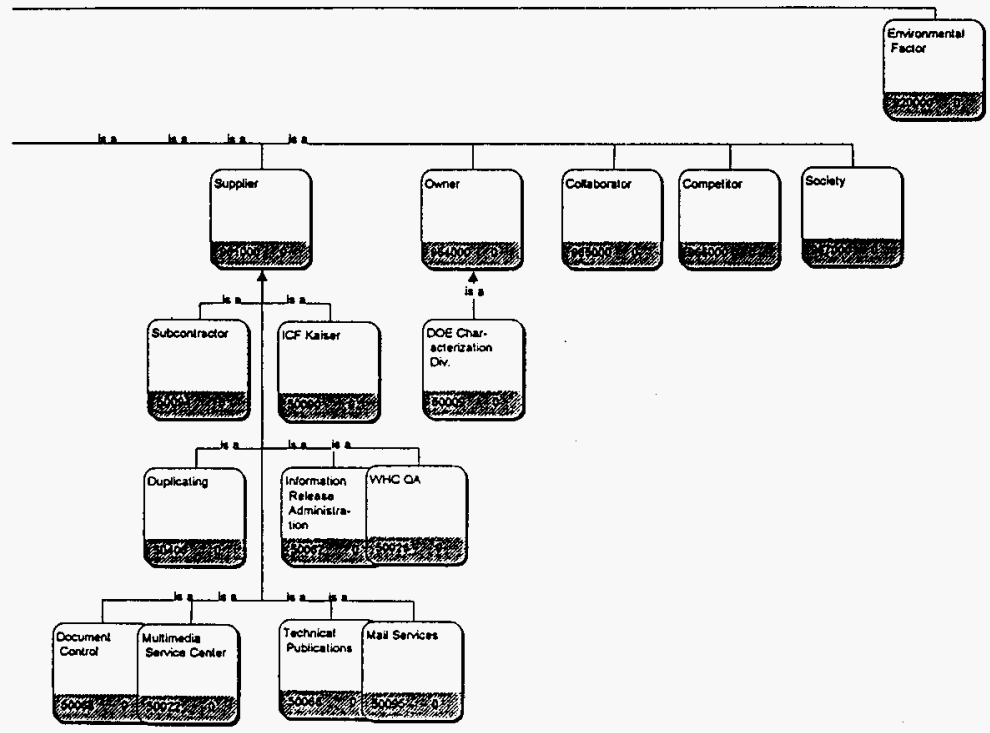


Table 2-1. Dynamic Process Model Dictionary. (21 sheets)

\begin{tabular}{|c|c|c|}
\hline Event name & Ref. \# & Event description \\
\hline $\begin{array}{l}\text { Analysis Chemist } \\
\text { Reviewed }\end{array}$ & 50071 & $\begin{array}{l}\text { The data are reviewed by the laboratory chemist to validate the analysis, e.g., check for } \\
\text { calculation and transcription errors, and to evaluate the QC analysis that accompanied the } \\
\text { primary analysis. }\end{array}$ \\
\hline Analysis Logged In & 50067 & The analyses that will be performed are recorded in the LABCORE System. \\
\hline $\begin{array}{l}\text { Analyze Safety } \\
\text { Constraints }\end{array}$ & 50068 & $\begin{array}{l}\text { This sub-event is a decision process and is included solely for clarification of the process flow in } \\
\text { the DPM. The activity actually occurs as part of the } 45 \text { - and } 60 \text {-day report preparation process. } \\
\text { Either } 45 \text { - or } 60 \text {-day reports can lead to a } 90 \text {-day report or directly to a final (105-day) report. }\end{array}$ \\
\hline $\begin{array}{l}\text { Anomalous Data } \\
\text { Reviewed }\end{array}$ & 50010 & $\begin{array}{l}\text { When an immediate notification is made during the analysis of the samples, the Safety Review } \\
\text { Committee will meet to review the available data from the tank, including the information from } \\
\text { the current sampling event. The project coordinator presents the data to the Safety Review } \\
\text { Committee which then deliberates and makes recommendations for changes in the tank safety } \\
\text { status and/or operational controls. These recommendations are recorded in safety review } \\
\text { meeting minutes. The process of acting on these recommendations is outside the scope of this } \\
\text { investigation. }\end{array}$ \\
\hline $\begin{array}{l}\text { Bench Plan } \\
\text { Generated }\end{array}$ & 50063 & $\begin{array}{l}\text { The bench plan describes the samples and their respective analyses. The initial bench plan is } \\
\text { prepared before the extrusion. }\end{array}$ \\
\hline Bench Plan Revised & 50065 & The bench plan is revised, as necessary, depending on the percent recovery of the cores. \\
\hline Cask Received & 50062 & $\begin{array}{l}\text { The shipping cask from the tank farms is brought into the laboratory hot cell. The cores are } \\
\text { removed from the cask and transferred to the extrusion station and/or local in-cell holding area. } \\
\text { Simultaneously, the Chain-of-Cusrody form is signed off and transferred to the laboratory } \\
\text { personnel. }\end{array}$ \\
\hline
\end{tabular}


Table 2-1. Dynamic Process Model Dictionary. (21 sheets)

\begin{tabular}{|c|c|c|}
\hline Event name & Ref. \# & Event description \\
\hline $\begin{array}{l}\text { Comments } \\
\text { Dispositioned }\end{array}$ & 50024 & $\begin{array}{l}\text { All comments from the external reviewers, if not submitted on RCR forms, are transcribed to } \\
\text { RCR forms and formally dispositioned. The program manager is responsible for the } \\
\text { dispositions. If comment resolution meetings are held, they are coordinated by the } \\
\text { Characterization Technical Basis organization and attended by the DQO document author, the } \\
\text { DQO facilitator, and subject matter experts. }\end{array}$ \\
\hline Core Extruded & 50064 & $\begin{array}{l}\text { Extrusion is the removal of a core from the core barrel (sampling device). In the process, the } \\
\text { amount of core recovery is evaluated as is the layering (coloration patterns, solid-liquid } \\
\text { divisions). Drainable liquid is collected and volume measured. The process is videotaped for } \\
\text { later reference if so desired. The extrusion event continues with the core being broken up into } \\
\text { subsamples based on the analysis being requested and the percent recovery of the core. Parent } \\
\text { samples in either full, one-half, or one-fourth segments are taken. These samples are stored in } \\
\text { the hot cell until required for subsampling. }\end{array}$ \\
\hline $\begin{array}{l}\text { Data Packages } \\
\text { Issued }\end{array}$ & 50007 & $\begin{array}{l}\text { This composite event includes all activities involved in producing the hard copy sample analysis } \\
\text { reports (see Figure } 2-8 \text { ). The hard copy data report is transcribed to WordPerfect }{ }^{1} \text { and/or } \\
\text { EXCEL }{ }^{2} \text { spreadsheets (or equivalents) for interpretation and evaluation. Four different data } \\
\text { report versions are possible depending on several factors: tank Watchlist status, the data, and } \\
\text { the quality of the data. These four report versions are respectively } 45-, 60-, 90-\text {, and final } \\
\text { (105-day) reports. The naming of the reports indicates the due date for release based on receipt } \\
\text { of the samples in the laboratory. The } 60 \text { - and } 90 \text {-day reports, if required, are issued as ECNs to } \\
\text { the } 45 \text {-day report. The final report constitutes a complete revision of the } 45 \text {-day report and } \\
\text { includes all data resulting from the sampling report. The project coordinator has the option of } \\
\text { preparing the data report or using the services of a subcontractor (currently Los Alamos } \\
\text { Technical Associates). }\end{array}$ \\
\hline Data QA Approved & 50073 & $\begin{array}{l}\text { The QA approval is the final validation required before the data can be uploaded to the TCD. } \\
\text { The QA approval is based on a review of the QC analysis performed on the sample. }\end{array}$ \\
\hline
\end{tabular}


Table 2-1. Dynamic Process Model Dictionary. (21 sheets)

\begin{tabular}{|c|c|c|}
\hline Event name & Ref. \# & Event description \\
\hline $\begin{array}{l}\text { Data Quality } \\
\text { Objective Document } \\
\text { Approved and } \\
\text { Released }\end{array}$ & 50027 & $\begin{array}{l}\text { After RL and Ecology approval, the author and the Characterization Technical Basis organization } \\
\text { sign the document. The author is responsible for obtaining the necessary signatures. The } \\
\text { appropriate TWRS Program manager then provides the final signature for the document. After } \\
\text { approval, the document is released and in effect. }\end{array}$ \\
\hline Data Uploaded & 50074 & $\begin{array}{l}\text { The final step is to upload the data from LABCORE to the TCD. Efforts are underway to make } \\
\text { this step fully electronic and automatic. Automatic verification and validation of data (e.g., } \\
\text { correct formats and range checking) are being incorporated. }\end{array}$ \\
\hline Digestate Analyzed & 50070 & $\begin{array}{l}\text { The carrier fluid is analyzed in accordance with the bench plan using one or more of ICP, } \\
\text { GFAA, ion chromatograph, or other instruments. The results are recorded on the analysis } \\
\text { records and entered into LABCORE. It is at this point that the immediate notification flag is } \\
\text { raised (by LABCORE) should a safety limit be exceeded by the data just entered. The flag } \\
\text { causes the immediate notification to be sent and a data review process to be initiated. }\end{array}$ \\
\hline Document Revised & 50020 & $\begin{array}{l}\text { If necessary, the document is further revised before the second stakeholder meeting as a result of } \\
\text { the internal and stakeholder reviews. }\end{array}$ \\
\hline
\end{tabular}


Table 2-1. Dynamic Process Model Dictionary. (21 sheets)

\begin{tabular}{|c|c|c|}
\hline Event name & Ref. \# & Event description \\
\hline DQOs Developed & 50001 & $\begin{array}{l}\text { Multiple sources of requirements received from internal customers, DOE, regulators, } \\
\text { stakeholders, and Defense Nuclear Facilities Safety Board findings are blended in the DQO } \\
\text { process. This process is aimed at determining the data required to make decisions under } \\
\text { uncertainty and maintaining a user-specified error rate. The DQO process is sponsored and } \\
\text { developed by the EPA. } \\
\text { The process starts with a customer or external agent identifying a tank waste data need. The } \\
\text { data need is an issue or concern with some aspect of the tank contents. It may be a safety issue } \\
\text { related to the amount of hydrogen in the tank or an issue related to the composition of the waste } \\
\text { affecting an anticipated waste treatment process. Once the data need is identified, the DQO is } \\
\text { prepared. The Characterization Technical Basis organization supports this process by assigning } \\
\text { a DQO facilitator and other personnel to guide the customer through the DQO process. } \\
\text { This composite event expands into another layer of sub-events that shows the detailed steps } \\
\text { involved in the DQO preparation process (see Figure 2-3). }\end{array}$ \\
\hline Draft Data Reported & 50072 & $\begin{array}{l}\text { The project coordinator downloads the data from LABCORE for use in the data reports (45-, } \\
60-, 90-\text {, and } 105 \text {-day reports). To meet a publication deadline for a particular report, the } \\
\text { project coordinator often accesses the data before the chemist and QA personnel have completed } \\
\text { their validation of the data. }\end{array}$ \\
\hline $\begin{array}{l}\text { Draft DQO } \\
\text { Prepared }\end{array}$ & 50014 & $\begin{array}{l}\text { After the stakeholder meeting, the author (with assistance from the DQO facilitator and } \\
\text { appropriate subject matter experts) prepares the initial draft (or revision) of the DQO. }\end{array}$ \\
\hline $\begin{array}{l}\text { Draft DQO } \\
\text { Supporting } \\
\text { Document } \\
\text { Assembled }\end{array}$ & 50015 & $\begin{array}{l}\text { The author completes the document and prepares it for review. For consistency, the document } \\
\text { should be assembled by a Media Service Center (although the author can, optionally, do this } \\
\text { work without such services). The document is prepared as a WHC SD. }\end{array}$ \\
\hline
\end{tabular}


Table 2-1. Dynamic Process Model Dictionary. (21 sheets)

\begin{tabular}{|c|c|c|}
\hline Event name & Ref. \# & Event description \\
\hline $\begin{array}{l}\text { Draft Review } \\
\text { Completed }\end{array}$ & 50044 & $\begin{array}{l}\text { The technically reviewed draft is sent for WHC internal review and DOE review. The WHC } \\
\text { internal reviewer is the manager of the project coordinator (functional review). The DOE } \\
\text { review is performed by DOE staff and/or DOE subcontractor support (e.g., MACTEC). The } \\
\text { internal review is documented via returned markups. The DOE review is documented via a } \\
\text { comment letter. The project coordinator resolves the comments with the reviewers. In the case } \\
\text { of the DOE comments, the resolution is documented in a comment response letter that is } \\
\text { returned to DOE (and those on distribution). A Media Service Center incorporates the markups } \\
\text { into the electronic file and produces a new (review completed) hard copy of the TCR. }\end{array}$ \\
\hline $\begin{array}{l}\text { Draft Technically } \\
\text { Reviewed }\end{array}$ & 50042 & $\begin{array}{l}\text { The project coordinator circulates hard copies of the draft TCR to one or more colleagues for } \\
\text { their technical review of the document. The reviews are typically documented in the form of } \\
\text { markups of the document that are returned to the project coordinator. After the project } \\
\text { coordinator reviews these markups and resolves the reviewers' comments, a Media Service } \\
\text { Center incorporates the markups into the electronic file and produces a new hard copy draft } \\
\text { TCR. }\end{array}$ \\
\hline EDT Prepared & 50048 & The project coordinator prepares the EDT that will be attached to the completed TCR. \\
\hline EDT Signed & 50049 & The project manager obtains the required signatures on the EDT. \\
\hline $\begin{array}{l}\text { Expert Panel } \\
\text { Review Completed }\end{array}$ & 50016 & $\begin{array}{l}\text { The completed draft SD is reviewed by a panel of technical experts selected by the program } \\
\text { manager. The technical experts can include internal personnel and consultants. This review } \\
\text { ensures that the document is technically accurate and that any data-gathering activities are } \\
\text { technically feasible. This is an informal review and RCR forms are not generated. This activity } \\
\text { would not take place during a DQO revision. }\end{array}$ \\
\hline $\begin{array}{l}\text { External Review } \\
\text { Completed }\end{array}$ & 50023 & $\begin{array}{l}\text { This is a formal review and the external reviewers formally submit their comments by the date } \\
\text { specified in the transmittal letter. The program manager is responsible for interfacing with the } \\
\text { external reviewers. }\end{array}$ \\
\hline
\end{tabular}


Table 2-1. Dynamic Process Model Dictionary. (21 sheets)

\begin{tabular}{|c|c|c|}
\hline Event name & Ref. \# & Event description \\
\hline $\begin{array}{l}\text { Field Instructions } \\
\text { Developed }\end{array}$ & 50004 & $\begin{array}{l}\text { This event uses the TCP, direct orders, and the expertise of the field sampling crews to develop } \\
\text { work packages that will control the work of collecting physical samples from a tank and } \\
\text { transporting them to the laboratory. }\end{array}$ \\
\hline $\begin{array}{l}\text { Final Data Package } \\
\text { Transmitted }\end{array}$ & 50039 & $\begin{array}{l}\text { If the project coordinator decides to use the services of a subcontractor to prepare the TCR, the } \\
\text { final data package is duplicated and sent to the subcontractor. Plant mail services may be used, } \\
\text { but the document may also be hand carried. The data package sent generally includes only the } \\
\text { hard copy data report and not any of the previously developed electronic files. }\end{array}$ \\
\hline $\begin{array}{l}\text { Final Data Quality } \\
\text { Objective Document } \\
\text { Prepared }\end{array}$ & 50025 & $\begin{array}{l}\text { After comment disposition, the document is revised as necessary and prepared for approval and } \\
\text { public release. Any required document clearance processes are completed at this time. This } \\
\text { step is completed by the author and a Media Service Center, with assistance from the DQO } \\
\text { facilitator and subject matter experts as necessary. }\end{array}$ \\
\hline $\begin{array}{l}\text { Final Data Report } \\
\text { Published }\end{array}$ & 50036 & $\begin{array}{l}\text { A standard process is employed for the publication of documents. The project coordinator will } \\
\text { obtain an informal peer review from colleagues, resolve the comments, work with a Media } \\
\text { Service Center to produce a properly edited and formatted document, and obtain the necessary } \\
\text { approvals for release of the document. }\end{array}$ \\
\hline $\begin{array}{l}\text { Final Data Report } \\
\text { Written }\end{array}$ & 50035 & $\begin{array}{l}\text { The final data report, also known as the 105-day report, includes the information from the } \\
\text { previous data reports ( } 45-\text { or } 60-\text { and } 90-\text { day, if written) and provides additional analysis and } \\
\text { interpretation of the concentration data. The project coordinator obtains a hard copy data report } \\
\text { from the LABCORE database and enters the data into WordPerfect tables and/or Spreadsheet } \\
\text { tables. After validating the data entry, perhaps with the help of the laboratory staff, the project } \\
\text { coordinator analyzes and interprets the data to produce an estimate of the tank inventory in terms } \\
\text { of tank average concentrations. Prior estimates from previous sampling events and modeling } \\
\text { efforts are used in this estimate. The estimation process is ad hoc and depends on the project } \\
\text { coordinator's interpretation of the data quality and sample validity (i.e., "representativeness"). }\end{array}$ \\
\hline
\end{tabular}


Table 2-1. Dynamic Process Model Dictionary. (21 sheets)

\begin{tabular}{|c|c|c|}
\hline Event name & Ref. \# & Event description \\
\hline $\begin{array}{l}\text { Fiscal Year } \\
\text { Characterization } \\
\text { Plan Developed }\end{array}$ & 50059 & $\begin{array}{l}\text { This event results in a fiscal year TWAP. The TWAP directs the sampling activities for the } \\
\text { fiscal year in which it is prepared. It is prepared in August for the following fiscal year by the } \\
\text { Characterization Technical Basis organization. The TWAP is based on the sampling schedule, } \\
\text { any specific TWRS Program element waste analysis plans, the Hanford analytical services QA } \\
\text { plan, the TWRS characterization program QA plan, and the proposed fiscal year budget as } \\
\text { estimated in August. }\end{array}$ \\
\hline $\begin{array}{l}\text { Formal Document } \\
\text { Preparation } \\
\text { Completed }\end{array}$ & 50022 & $\begin{array}{l}\text { All changes resulting from the formal internal review and the second stakeholders' meeting are } \\
\text { made and the document is prepared for transmittal to the external stakeholders (RL, EPA, and } \\
\text { Ecology) for final review. The author is responsible for final preparation of the document. A } \\
\text { Media Service Center will normally prepare the copy for transmittal to the stakeholders. }\end{array}$ \\
\hline $\begin{array}{l}\text { Forty-Five Day } \\
\text { Report Published }\end{array}$ & 50029 & $\begin{array}{l}\text { This sub-event makes use of a standard process for the publication of documents. The project } \\
\text { coordinator obtains an informal peer review from colleagues, resolves the comments, works with } \\
\text { a Media Service Center to produce a properly edited and formatted document, and obtains the } \\
\text { necessary approvals for release of the document. }\end{array}$ \\
\hline $\begin{array}{l}\text { Forty-Five Day } \\
\text { Report Written }\end{array}$ & 50028 & $\begin{array}{l}\text { The project coordinator obtains a hard copy data report from the LABCORE database and enters } \\
\text { the data into WordPerfect tables and/or Spreadsheet tables. After validating the data entry, } \\
\text { perhaps with the help of the laboratory staff, the data are compared against several Safety-related } \\
\text { DQOs to determine the safety status of the tank (DSCG, total alpha). If a safety limit is } \\
\text { violated, a need for performing a secondary analysis (i.e., 90-day data report) is generated. } \\
\text { Text describing the comparisons is prepared. Also prepared for inclusion in the 45-day report is } \\
\text { a summary of the sampling event and a description of the samples and any subsampling } \\
\text { processes. These descriptions are prepared with the support of the laboratory staff. }\end{array}$ \\
\hline $\begin{array}{l}\text { Information Release } \\
\text { Request Completed }\end{array}$ & 50047 & $\begin{array}{l}\text { The project coordinator completes the IRR that must be attached to the completed TCR before } \\
\text { review by Information Release Administration. Upon approval for release, a Release } \\
\text { Authorization form is prepared with an official stamp. }\end{array}$ \\
\hline
\end{tabular}


Table 2-1. Dynamic Process Model Dictionary. (21 sheets)

\begin{tabular}{|c|c|c|}
\hline Event name & Ref. \# & Event description \\
\hline $\begin{array}{l}\text { Internal Review } \\
\text { Completed }\end{array}$ & 50018 & $\begin{array}{l}\text { This sub-event is the formal WHC internal review and includes peers, appropriate management, } \\
\text { safety and QA personnel, and the expert panel previously selected by the program manager. } \\
\text { Comments are recorded on RCR forms and formally dispositioned. Comment resolution } \\
\text { meetings are held if necessary. This review is coordinated and tracked by the document author. } \\
\text { This activity takes place concurrently with the stakeholder review. }\end{array}$ \\
\hline $\begin{array}{l}\text { Ninety-Day Report } \\
\text { Published }\end{array}$ & 50034 & $\begin{array}{l}\text { This sub-event makes use of a standard process for the publication of documents. The project } \\
\text { coordinator obtains an informal peer review from colleagues, resolves the comments, works with } \\
\text { a Media Service Center to produce a properly edited and formatted document, and obtains the } \\
\text { necessary approvals for release of the document. }\end{array}$ \\
\hline $\begin{array}{l}\text { Ninety-Day Report } \\
\text { Written }\end{array}$ & 50033 & $\begin{array}{l}\text { The project coordinator obtains a hard copy data report from the LABCORE database and enters } \\
\text { the data into WordPerfect tables and/or Spreadsheet tables. After validating the data entry, } \\
\text { perhaps with the help of the laboratory staff, the project coordinator analyzes and interprets the } \\
\text { data. The focus of the analysis process is to provide an understanding of why the safety criteria } \\
\text { reported in either the } 45-\text { or } 60 \text {-day data reports were exceeded, e.g., the tank contains a high } \\
\text { level of organics, cyanide, or possibly }{ }^{239 / 240} \mathrm{Pu} \text { or metals. }\end{array}$ \\
\hline $\begin{array}{l}\text { Pre-Login } \\
\text { Completed }\end{array}$ & 50061 & $\begin{array}{l}\text { This event establishes the "project" within the LABCORE System and prepares the system to } \\
\text { receive data describing the sample breakdown and requested analysis. All data within } \\
\text { LABCORE are organized into "projects" which, in usage, are synonymous with sampling events. }\end{array}$ \\
\hline Resources Identified & 50037 & $\begin{array}{l}\text { The project coordinator has the option of preparing the TCR directly or using the services of a } \\
\text { subcontractor. The choice is driven by the available time for the project coordinator and } \\
\text { nearness of the deadline for issuing the TCR. The preference is to use the subcontractor. The } \\
\text { result of the event is the choice of the designated author, either the project coordinator or the } \\
\text { subcontractor. }\end{array}$ \\
\hline $\begin{array}{l}\text { RL/Ecology } \\
\text { Concurrence } \\
\text { Received }\end{array}$ & 50026 & $\begin{array}{l}\text { After final document preparation, concurrence is obtained from RL and Ecology by obtaining } \\
\text { signatures from the appropriate RL and Ecology personnel on a signature page that is part of the } \\
\text { DQO document. }\end{array}$ \\
\hline
\end{tabular}


Table 2-1. Dynamic Process Model Dictionary. (21 sheets)

\begin{tabular}{|c|c|c|}
\hline Event name & Ref. \# & Event description \\
\hline Samples Analyzed & 50006 & $\begin{array}{l}\text { This composite event uses the delivered samples in a series of physical and chemical analyses. } \\
\text { The output are data in the LABCORE System. LABCORE automatically flags certain } \\
\text { safety-related data if the data exceed a preset value. The flag causes an immediate notification } \\
\text { of the Safety customer via a phone call, followed by an internal memo within } 1 \text { day of the flag } \\
\text { being set. This event also results in a series of hard copy data reports that are used by the } \\
\text { project coordinator to build data interpretations and report the results of the sample analysis. }\end{array}$ \\
\hline Samples Collected & 50005 & $\begin{array}{l}\text { This event applies the directions embodied in the work packages to the physical collection of } \\
\text { tank samples and transportation of them to the laboratory. The products of this event are } \\
\text { samples delivered to the laboratory. Completion of this event starts a countdown clock for the } \\
\text { issuance of the data reports. }\end{array}$ \\
\hline Samples Digested & 50069 & $\begin{array}{l}\text { The solid material in the sample must be "digested," i.e., dissolved in a carrier fluid, before the } \\
\text { analysis can be carried out. The carrier fluid chosen depends on the measurement protocol } \\
\text { being used. The fluid is also diluted as necessary to bring the anticipated concentration within } \\
\text { the measurement range of the instruments being used. The dilutions are recorded in the } \\
\text { digestion log. }\end{array}$ \\
\hline Samples Logged In & 50066 & The sample numbers and parent-child relationships are entered into LABCORE. \\
\hline Samples Retrieved & 50068 & $\begin{array}{l}\text { The parent samples are retrieved from the in-cell storage and subsamples (child samples and } \\
\text { archive samples) taken, as required. The child samples are small enough that the total amount } \\
\text { of material, and thus the amount of activity being handled, is reduced to the point where the } \\
\text { subsamples can be removed from the hot cell and handled in a fume hood or glove box. It is } \\
\text { common practice for the project coordinator to have specified that duplicate subsamples be taken } \\
\text { at this point in the process. }\end{array}$ \\
\hline
\end{tabular}


Table 2-1. Dynamic Process Model Dictionary. (21 sheets)

\begin{tabular}{|l|l|l|}
\hline \multicolumn{1}{|c|}{ Event name } & Ref. \# & \multicolumn{1}{|c|}{ Event description } \\
\hline $\begin{array}{l}\text { Sampling and } \\
\text { Analysis Plan } \\
\text { Developed }\end{array}$ & 50003 & $\begin{array}{l}\text { This event produces the SAP for a sampling event. The project coordinator uses the TCP, any } \\
\text { applicable direct orders and test plans, laboratory and sampling engineering staff knowledge, } \\
\text { DQO information, surveillance information, sampling schedule, and sampling schedule revisions } \\
\text { to provide a set of directions for the analysis of tank samples. }\end{array}$ \\
$\tilde{\leftarrow}$ & $\begin{array}{l}\text { The project coordinator uses the SAPs previously developed for other sampling events with } \\
\text { matching characteristics as inputs to write a new SAP. }\end{array}$ \\
\hline $\begin{array}{l}\text { Sampling Priorities } \\
\text { Established }\end{array}$ & 50057 & $\begin{array}{l}\text { The Characterization program, with input from the TWRS Program elements, develops a } \\
\text { sampling priority list by assessing programmatic needs and priorities. The DQOs provide a } \\
\text { major input to this prioritization effort. }\end{array}$ \\
\hline $\begin{array}{l}\text { Sequirements } \\
\text { Developed }\end{array}$ & $\begin{array}{l}\text { This composite event (see sub-events in Figure 2-5) establishes and coordinates the sampling } \\
\text { requirements for each sampling event and reconciles them with the available budget and known } \\
\text { operational constraints on tank access and resource scheduling. The primary outputs of this } \\
\text { event are a sampling schedule and a TCP for each tank to be sampled during the fiscal year. }\end{array}$ \\
\hline
\end{tabular}


Table 2-1. Dynamic Process Model Dictionary. (21 sheets)

\begin{tabular}{|c|c|c|}
\hline Event name & Ref. \# & Event description \\
\hline $\begin{array}{l}\text { Sampling Schedule } \\
\text { Defined }\end{array}$ & 50058 & $\begin{array}{l}\text { A fiscal year sampling schedule is generated from the sampling priority list. This schedule is } \\
\text { determined based on a number of scheduling constraints and additional requirements such as that } \\
\text { to give Watchlist tanks the highest priority. Tri-Party Agreement }{ }^{3} \text { Milestone M-44-00 specifies } \\
\text { the number of tanks that must be characterized each year. Scheduling constraints include the } \\
\text { following: } \\
\text { - The time required for preparing significant documentation including safety analysis } \\
\text { reports, environmental assessments, Narional Environmental Policy Act of } 1969 \\
\text { documentation, and readiness reviews necessary before initiating any core sampling events } \\
\text { in Watchlist tanks } \\
\text { - Worker health and safety vapor sampling of Watchlist tanks before further sampling } \\
\text { activities } \\
\text { - Accessibility of tank via selected risers } \\
\text { Monitoring instrumentation and safety evaluations required in potential flammable gas } \\
\text { generators before entering these tanks } \\
\text { Geographical locations (to optimize sampling crews) } \\
\text { Laboratory capacity constraints. }\end{array}$ \\
\hline SAP Reviewed & 50057 & $\begin{array}{l}\text { The project coordinator reviews the SAP and determines which data reports will be required. } \\
\text { The } 45 \text {-day report is required if the tank is not expected to contain ferrocyanide. If the tank is } \\
\text { on the Ferrocyanide Watchlist or is expected to contain ferrocyanide, a } 60 \text {-day report is } \\
\text { required. These two reports are mutually exclusive. }\end{array}$ \\
\hline
\end{tabular}


Table 2-1. Dynamic Process Model Dictionary. (21 sheets)

\begin{tabular}{|c|c|c|}
\hline Event name & Ref. \# & Event description \\
\hline SD Draft Revised & 50017 & $\begin{array}{l}\text { Any changes identified during the expert panel review are incorporated. The revised draft is } \\
\text { then input into the next two activities depicted on the diagram, which take place simultaneously. }\end{array}$ \\
\hline $\begin{array}{l}\text { SD Release Page } \\
\text { Prepared }\end{array}$ & 50046 & $\begin{array}{l}\text { The project coordinator prepares an SD release page. This page, when stamped, constitutes } \\
\text { approval to release the TCR. }\end{array}$ \\
\hline $\begin{array}{l}\text { Second Stakeholder } \\
\text { Meeting Held }\end{array}$ & 50021 & $\begin{array}{l}\text { This is a working meeting conducted in the same manner as the first meeting. The participants } \\
\text { should be the same as for the first meeting. This meeting allows the stakeholders to discuss and } \\
\text { agree on the draft of the DQO document. Additional stakeholder meetings will be held until all } \\
\text { unresolved issues are completed. }\end{array}$ \\
\hline $\begin{array}{l}\text { Sixty-Day Report } \\
\text { Published }\end{array}$ & 50032 & $\begin{array}{l}\text { This sub-event makes use of a standard process for the publication of documents. The project } \\
\text { coordinator obtains an informal peer review from colleagues, resolves the comments, works with } \\
\text { a Media Service Center to produce a properly edited and formatted document, and obtains the } \\
\text { necessary approvals for release of the document. }\end{array}$ \\
\hline $\begin{array}{l}\text { Sixty-Day Report } \\
\text { Written }\end{array}$ & 50031 & $\begin{array}{l}\text { The project coordinator obtains a hard copy data report from the LABCORE database and enters } \\
\text { the data into WordPerfect tables and/or Spreadsheet tables. After validating the data entry, } \\
\text { perhaps with the help of the laboratory staff, the data are compared against several Safety-related } \\
\text { DQOs to determine the safety status of the tank (DSCG, total alpha, ferrocyanide). If a safety } \\
\text { limit is violated, a need for performing a secondary analysis (i.e., 90-day data report) is } \\
\text { generated. Text describing the comparisons is prepared. Also prepared for inclusion in the } \\
60 \text {-day report is a summary of the sampling event and a description of the samples and any } \\
\text { subsampling processes. These descriptions are prepared with the support of the laboratory staff. }\end{array}$ \\
\hline $\begin{array}{l}\text { Spectator Draft } \\
\text { Polished }\end{array}$ & 50043 & $\begin{array}{l}\text { The draft received from the subcontractor is given to a Media Service Center which recombines } \\
\text { the text and graphics according to the hard copy report and makes the electronic file available to } \\
\text { the project coordinator. The project coordinator reviews and edits the document as required } \\
\text { (edits may be in the form of markups to either the hard copy or the electronic file). The Media } \\
\text { Service Center takes the markup(s) and technically edits the document producing a draft TCR. }\end{array}$ \\
\hline
\end{tabular}




\begin{tabular}{|c|c|c|}
\hline 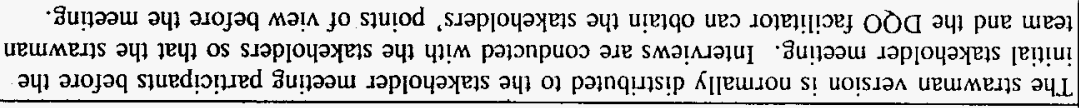 & ZIOOS & 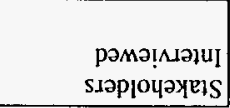 \\
\hline 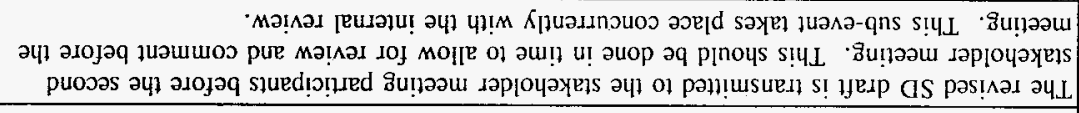 & 61005 & 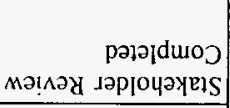 \\
\hline 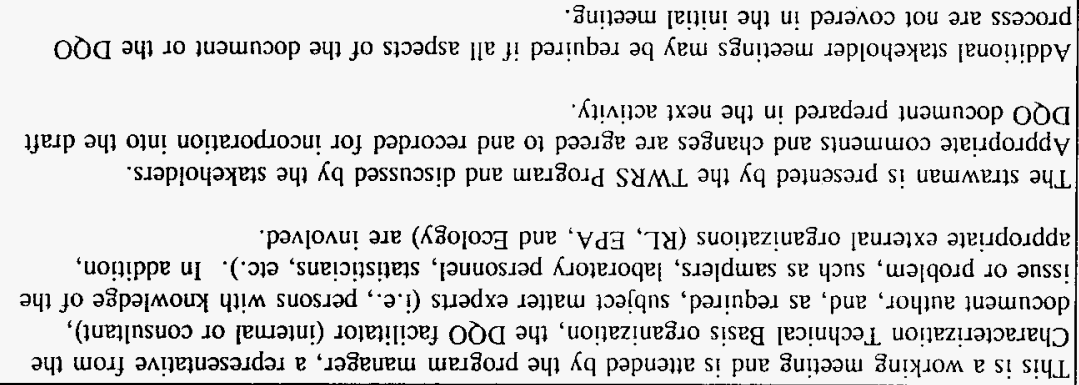 & $\varepsilon$ IOOS & 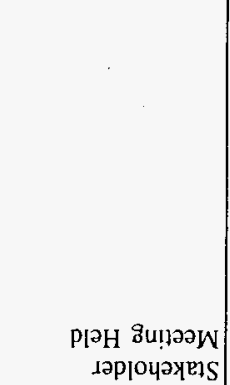 \\
\hline 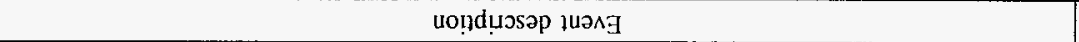 & \# "כગ & 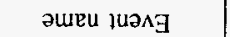 \\
\hline
\end{tabular}

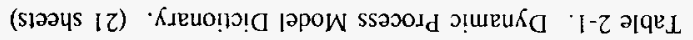


Table 2-1. Dynamic Process Model Dictionary. (21 sheets)

\begin{tabular}{|l|c|l|}
\hline \multicolumn{1}{|c|}{ Event name } & Ref. \# & \multicolumn{1}{c|}{ Event description. } \\
\hline $\begin{array}{l}\text { Strawman } \\
\text { Developed }\end{array}$ & 50011 & $\begin{array}{l}\text { While creation of a DQO is the responsibility of the program requiring the information, the } \\
\text { TWRS DQO process involves participation by and, ultimately, approval from, TWRS } \\
\text { stakeholders. The DQO contents are defined in meetings with the stakeholders. } \\
\text { To expedite the first stakeholder meeting, a strawman team, consisting of the program manager, } \\
\text { a representative from the Characterization Technical Basis organization, the DQO facilitator } \\
\text { (internal or consultant), document author, and a person knowledgeable of the issue or problem, } \\
\text { conducts a meeting or series of meetings to prepare a "strawman" version of the DQO that is } \\
\text { distributed to the stakeholders (and other meeting participants) before the meeting. Experience } \\
\text { has shown that creating this "starting point" document helps to focus the meeting and reduces the } \\
\text { amount of time required to develop a draft DQO. } \\
\ddot{s}\end{array}$ \\
For a general revision to an existing DQO, the current version is used as the strawman.
\end{tabular}


Table 2-1. Dynamic Process Model Dictionary. (21 sheets)

\begin{tabular}{|c|c|c|}
\hline Event name & Ref. \# & Event description \\
\hline $\begin{array}{l}\text { Subcontractor Draft } \\
\text { Prepared }\end{array}$ & 50040 & $\begin{array}{l}\text { The subcontractor draft TCR is prepared with the following steps: } \\
\text { - Data entry and validation } \\
\text { - Assigning sections of the draft to various authors } \\
\text { - Rearch for relevant data from the Tank Characterization Resource Center } \\
\text { - Obtaining temperature data from Surveillance Analysis Computer System (spreadsheet) } \\
\text { - Obtaining Section } 2.0 \text { of the draft TCR from ICF KH, and reviewing and rewriting as } \\
\text { - Pecessary } \\
\text { - Assembling the document, merging sections, and embedding graphics } \\
\text { - Author's review of the assembled document, including a second review of the data entry } \\
\text { - Senior author technical review of the document. } \\
\text { The data analysis and interpretation process is not defined further at this time due to the } \\
\text { complex, fluid nature of the data analysis and the high dependence upon the author's } \\
\text { professional judgment and TwRS historical knowledge. }\end{array}$ \\
\hline
\end{tabular}


Table 2-1. Dynamic Process Model Dictionary. (21 sheets)

\begin{tabular}{|l|l|l|}
\hline \multicolumn{1}{|c|}{ Event name } & Ref. \# & \multicolumn{1}{c|}{ Event description } \\
\hline $\begin{array}{l}\text { Subcontractor Draft } \\
\text { Transmitted }\end{array}$ & 50041 & $\begin{array}{l}\text { The subcontractor delivers the initial draft to the project coordinator through the plant mail. The } \\
\text { draft is delivered in hard copy and electronic (disk) file formats. Typically, the electronic files } \\
\text { are segregated into text and graphics due to floppy disc storage limitations. }\end{array}$ \\
\hline $\begin{array}{l}\text { Tank } \\
\text { Characterization } \\
\text { Plan Prepared }\end{array}$ & 50060 & $\begin{array}{l}\text { A TCP is prepared for each tank sampling event scheduled in the TWAP. These plans serve as } \\
\text { contracts for analytical work between the TWRS Characterization Program and the performing } \\
\text { laboratory. TCPs integrate the sampling and analytical interests of all TWRS Program elements } \\
\text { for a given tank. }\end{array}$ \\
$\begin{array}{l}\text { TCPS may be written in conjunction with the TWAP or may be prepared later by the project } \\
\text { coordinator. Previous TCPS for similar tanks are used as input to this process. Other inputs } \\
\text { include tank surveillance information, any special test plans, and the DQOs applicable to the } \\
\text { sampling event. }\end{array}$
\end{tabular}


Table 2-1. Dynamic Process Model Dictionary. (21 sheets)

\begin{tabular}{|c|c|c|}
\hline Event name & Ref. \# & Event description \\
\hline Tanks Characterized & 50000 & $\begin{array}{l}\text { This composite event (see Figure 2-1) shows the main participants and product of the Waste } \\
\text { Tank Characterization program. This top-level characterization process consists of the following } \\
\text { sub-events: } \\
\text { - DQOs Developed } \\
\text { - Sampling Requirements Developed } \\
\text { - Sield Instructions Developed } \\
\text { - Samples Collected } \\
\text { - DCD Updated } \\
\text { - Anom Issued } \\
\text { This event is performed at least once and may be repeated, as necessary, for each tank. The } \\
\text { first pass results in a new TCR. Any subsequent passes result in revisions of the TCR for an } \\
\text { individual tank to enhance knowledge about the tank or determine if changes in previously } \\
\text { analyzed contents have occurred. This is the highest level event in the Characterization DPM. } \\
\text { It expands, through several layers, into all the detail events. The next level of events consists of } \\
\text { the following sub-events. }\end{array}$ \\
\hline TCD Updated & 50008 & $\begin{array}{l}\text { The TCD is periodically updated by the LABCORE System. This is an electronic transfer of } \\
\text { data from LABCORE to the TCD. Individuals from several different organizations are involved } \\
\text { in this process, characterized here as simply TCD support. There is an ongoing program to } \\
\text { expand the interface between LABCORE and TCD to include more data entities in the transfer } \\
\text { process. }\end{array}$ \\
\hline
\end{tabular}


Table 2-1. Dynamic Process Model Dictionary. (21 sheets)

\begin{tabular}{|c|c|c|}
\hline Event name & Ref. \# & Event description \\
\hline TCR Issued & 50009 & $\begin{array}{l}\text { This is a composite event that includes all sub-events required to produce the TCR (see } \\
\text { Figure } 2-9 \text { ). This activity produces the TCR that reports the current information known about } \\
\text { the contents of a specific tank. It is the release and acceptance of this document by EPA and } \\
\text { Ecology that fulfill the characterization requirements of the Tri-Party Agreement. }\end{array}$ \\
\hline $\begin{array}{l}\text { TCR Package } \\
\text { Assembled }\end{array}$ & 50050 & $\begin{array}{l}\text { The project coordinator combines the approved EDT, the SD release page, the Release } \\
\text { Authorization form, and the TCR to form a completed TCR package. }\end{array}$ \\
\hline $\begin{array}{l}\text { TCR Package } \\
\text { Released }\end{array}$ & 50051 & The completed package is given to Document Control for official release. \\
\hline $\begin{array}{l}\text { TCR Package } \\
\text { Reproduced }\end{array}$ & 50054 & $\begin{array}{l}\text { Multiple copies are prepared by Duplicating and distributed as instructed by the distribution list } \\
\text { attached to the TCR package. }\end{array}$ \\
\hline
\end{tabular}


Table 2-1. Dynamic Process Model Dictionary. (21 sheets)

\begin{tabular}{|c|c|c|}
\hline Event name & Ref. \# & Event description \\
\hline TCR Published & 50045 & $\begin{array}{l}\text { This is a composite event that further "expands" the process involved in publishing a TCR (see } \\
\text { Figure 2-10). The project coordinator typically takes the document through the publication } \\
\text { process. The process involves the following events. } \\
\text { - The project coordinator prepares an EDT and obtains the necessary signatures. The EDT, } \\
\text { SD release page, title page, and the TCR form a completed TCR package. } \\
\text { - The project coordinator prepares an IRR. } \\
\text { - The document is taken to Document Control which supplies a completed (stamped) SD } \\
\text { release page. } \\
\text { The IRR is reviewed by Document Control which produces a Release Authorization form } \\
\text { that is added, along with the EDT and SD Cover Sheet, to the TCR to form the assembled } \\
\text { TCR package. } \\
\text { If the TCR due date is imminent, the project coordinator reproduces a limited set of TCR } \\
\text { packages and hand delivers them to DOE to ensure the release date milestone is met. } \\
\text { The TCR package is given to a Media Service Center which manages the effort of } \\
\text { reproducing the document and distributing it to the TCR distribution list. } \\
\text { This process is part of the Information Release Administration domain and is undergoing review } \\
\text { within that organization. }\end{array}$ \\
\hline TCR Transmitted & 50055 & $\begin{array}{l}\text { If the TCR due date is imminent, the project coordinator reproduces a limited set of TCR } \\
\text { packages and hand delivers these to DOE to ensure the release date milestone is met. The } \\
\text { remaining packages are distributed via mail (in-plant or U.S. mail). }\end{array}$ \\
\hline
\end{tabular}


Table 2-1. Dynamic Process Model Dictionary. (21 sheets)

\begin{tabular}{|c|c|c|}
\hline Event name & Ref. \# & Event description \\
\hline $\begin{array}{l}\text { WHC Draft } \\
\text { Prepared }\end{array}$ & 50038 & $\begin{array}{l}\text { If the project coordinator has elected to write the draft report, the draft is prepared using the } \\
\text { following approximate steps: } \\
\text { - Data entry and validation (as required, or use prior electronic files developed during the } \\
\text { "Data Packages Issued" event) } \\
\text { - Search for relevant data from the Tank Characterization Resource Center } \\
\text { - Receipt of historical temperature data from ICF KH (spreadsheet) } \\
\text { - Obtaining temperature data from Surveillance Analysis Computer System (spreadsheet) } \\
\text { - Obtaining Section } 2.0 \text { of the draft TCR from ICF KH, and reviewing and rewriting as } \\
\text { - Performing the data analysis and interpretation, and documenting the results } \\
\text { - Assembling the document, merging sections, and embedding graphics } \\
\text { The draft TCR describes the sampling event, the safety status of the tanks, and the latest } \\
\text { inventory estimate. The current estimates are compared with prior data (previous sampling and } \\
\text { the historical tank contents estimates) to identify and interpret any significant trends. } \\
\text { Recommendations for further sampling are included. The data analysis and interpretation } \\
\text { process is not defined further at this time due to the complex, fluid nature of the data analysis } \\
\text { and the high dependence upon the project coordinator's professional judgment and TWRS } \\
\text { historical knowledge. }\end{array}$ \\
\hline
\end{tabular}


Table 2-1. Dynamic Process Model Dictionary. (21 sheets)

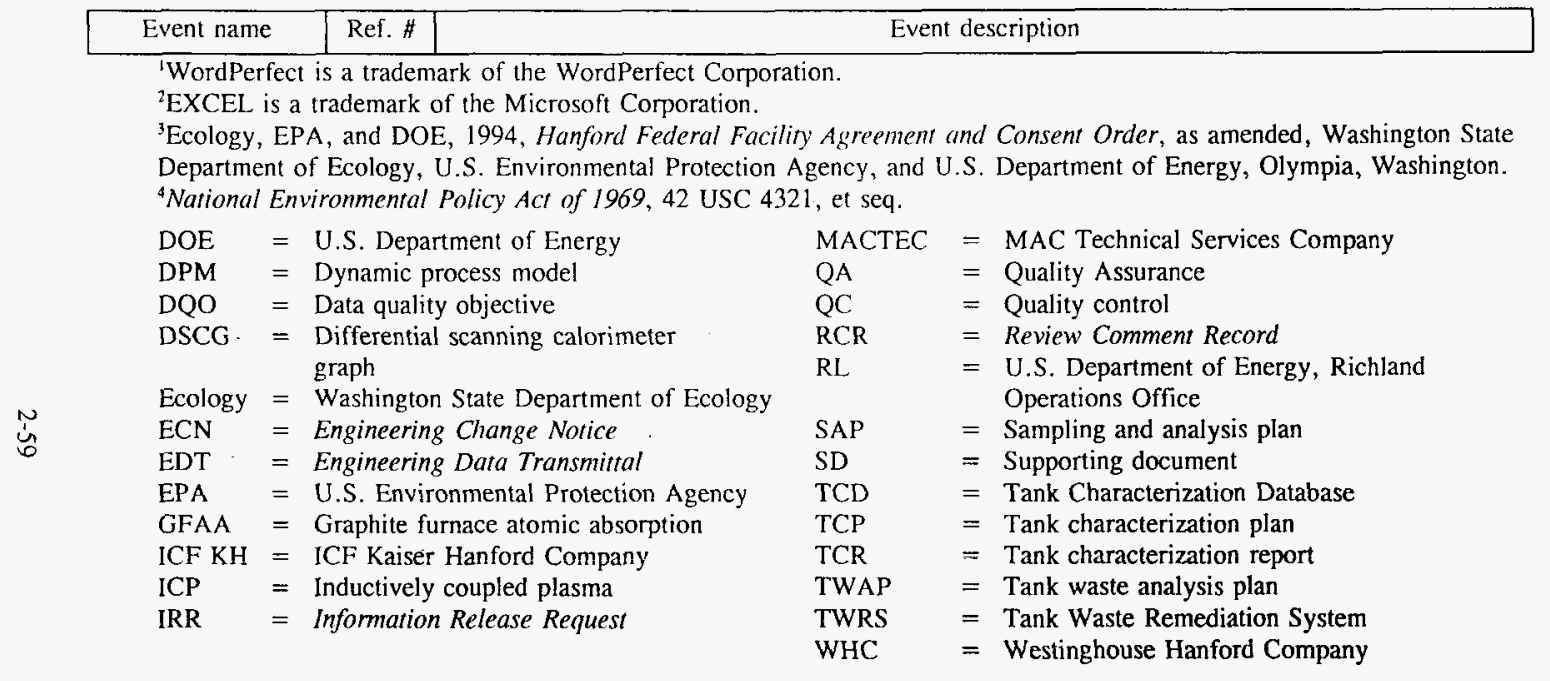


Table 2-2. Object Relationship Model Dictionary. (26 sheets)

\begin{tabular}{|c|c|c|}
\hline Participant name & Ref. \# & Participant description \\
\hline $\begin{array}{l}\text { 45-Day Data } \\
\text { Report }\end{array}$ & 50071 & $\begin{array}{l}\text { This is a preliminary safety screening report containing information on energetics via the DSC } \\
\text { and the TGA. The DSC/TGA data indicate the potential for the waste to undergo a spontaneous } \\
\text { exothermic reaction. }\end{array}$ \\
\hline $\begin{array}{l}\text { 60-Day Data } \\
\text { Report }\end{array}$ & 50075 & $\begin{array}{l}\text { This is the same as the } 45 \text {-Day Data Report with the addition of an analysis for the ferrocyanide } \\
\text { content of the tank. This report was used only for those tanks known to have had ferrocyanide } \\
\text { added to the waste. }\end{array}$ \\
\hline $\begin{array}{l}\text { 90-Day Data } \\
\text { Report }\end{array}$ & 50080 & $\begin{array}{l}\text { This is a secondary safety screening report, required only if the } 45-\text { or } 60 \text {-day reports showed } \\
\text { data in excess of an established safety screening limit. Data included here are moisture contents } \\
\text { and total organic carbon. }\end{array}$ \\
\hline $\begin{array}{l}\text { Abstract } \\
\text { Information } \\
\text { Resource }\end{array}$ & 934100 & These participants are generally sources of information or process triggers. \\
\hline ACE Form & 50429 & $\begin{array}{l}\text { ACE forms are used for simple data reduction activities. These are actually Quattro Pro' } \\
\text { spreadsheets in which instrument readings can be entered and basic calculations and data } \\
\text { conversions made. }\end{array}$ \\
\hline Analysis Record & 50434 & $\begin{array}{l}\text { The sample analysis records are kept in the LABCORE database. They track the course of the } \\
\text { sample through the analysis process and include any dilutions, spikes, splits, and associated QA } \\
\text { analysis and calculations (e.g., percent recovery of a spike). The record may be revised as a } \\
\text { result of a chemist's review of the analysis data and procedures. }\end{array}$ \\
\hline Bench Plan & 50431 & $\begin{array}{l}\text { The bench plan specifies the subsamples to be taken and the analysis to be performed on each of } \\
\text { the subsamples. The participant can be in one of two states: initial or revised. The initial } \\
\text { bench plan is based on the requirements of the SAP and is entered into LABCORE before the } \\
\text { sample is extruded. The bench plan is revised once the sample is extruded and the project } \\
\text { coordinator and the laboratory staff evaluate the core for available material to analyze. }\end{array}$ \\
\hline
\end{tabular}


Table 2-2. Object Relationship Model Dictionary. (26 sheets)

\begin{tabular}{|c|c|c|}
\hline Participant name & Ref. \# & Participant description \\
\hline Budget & 50003 & $\begin{array}{l}\text { This is the portion of the Hanford Site budget apportioned to the tank Characterization function. } \\
\text { The budget cycle is such that work must commence before the budget is approved by Congress. } \\
\text { Work commences on the basis of a proposed budget and continuing resolution. Plans are } \\
\text { revised once the budget is approved. The two states of this participant, therefore, are } \\
\text { "proposed" and "approved." }\end{array}$ \\
\hline $\begin{array}{l}\text { Chain-of-Custody } \\
\text { Form }\end{array}$ & 50432 & $\begin{array}{l}\text { The COC form tracks ownership of the samples from the time they are taken from a tank to the } \\
\text { point where the samples are received at the laboratory. Miscellaneous comments are also } \\
\text { included on the form. The COC form provides the link between the sampling point and the } \\
\text { laboratory subsamples. The form is signed by the laboratory and filed, but the COC data are } \\
\text { not currently captured in any electronic record. }\end{array}$ \\
\hline $\begin{array}{l}\text { Char. Requirements } \\
\text { Source }\end{array}$ & 50409 & $\begin{array}{l}\text { This category is used for a number of documents that provide requirements for tank } \\
\text { characterization work. These are: Direct Order (50048), DNFSB Finding (50008), OSD } \\
\text { (50092), Sampling Priority List (50039), Sampling Schedule (50051), Surveillance Information } \\
(50042) \text {, Test Plan (50036), Tri-Party Agreement Milestone M-44-00 (50040), and the Tri-Party } \\
\text { Agreement (50001). }\end{array}$ \\
\hline $\begin{array}{l}\text { Char. Technical } \\
\text { Basis Document }\end{array}$ & 50014 & $\begin{array}{l}\text { This document specifies the strategy for characterization of the Hanford Site tank wastes and } \\
\text { provides the basis for the strategy. It also describes the issues requiring characterization } \\
\text { information and the process of prioritizing tanks to obtain information. }\end{array}$ \\
\hline $\begin{array}{l}\text { Char. Test Plan - } \\
\text { Sample }\end{array}$ & 50036 & $\begin{array}{l}\text { Test Plan (50036). Test plans are special requests for data from a sampling event that do not } \\
\text { originate in the DQO process. }\end{array}$ \\
\hline $\begin{array}{l}\text { Characterization } \\
\text { Technical Basis } \\
\text { Org. }\end{array}$ & 50004 & $\begin{array}{l}\text { This TWRS organization plans characterization activities and documents the characterization } \\
\text { results. Its responsibilities include information needs and DQOs, evaluation and planning, } \\
\text { models and inventory, data assessment and interpretation, and data management. }\end{array}$ \\
\hline Comment cc:Mail ${ }^{2}$ & 50097 & $\begin{array}{l}\text { Comments about the draft TCR are returned by DOE Characterization staff to the project } \\
\text { coordinator via a comment on cc:Mail. }\end{array}$ \\
\hline
\end{tabular}


Table 2-2. Object Relationship Model Dictionary. (26 sheets)

\begin{tabular}{|l|l|l|}
\hline Participant name & Ref. \# & \multicolumn{1}{|c|}{ Participant description } \\
\hline $\begin{array}{l}\text { Comment Response } \\
\text { cc:Mail }\end{array}$ & 50099 & $\begin{array}{l}\text { The comments made by DOE Characterization staff are formally responded to in a comment } \\
\text { response via cc:Mail. The comments that are accepted are incorporated into the draft TCR. }\end{array}$ \\
\hline $\begin{array}{l}\text { Compatibility } \\
\text { Analysis }\end{array}$ & 50076 & $\begin{array}{l}\text { This is the analysis of the laboratory sample analysis results performed to satisfy the } \\
\text { requirements of the compatibility DQO. }\end{array}$ \\
\hline Compatibility DQO & 50073 & $\begin{array}{l}\text { This is the DQO written to support decisions as to the compatibility of wastes that are either } \\
\text { stored in, or may be received into, the Hanford Site double-shell tank system. The primary } \\
\text { goal is to ensure that safety and/or operations problems do not result from waste transfers. }\end{array}$ \\
\hline \multirow{2}{s}{} & $\begin{array}{l}\text { Core } \\
\text { Customer }\end{array}$ & $\begin{array}{l}\text { The core contains the material removed from the tank for the purpose of characterizing the tank } \\
\text { contents. Other sampling schemes are possible, e.g., gas and pure liquid samples, but the } \\
\text { primary characterization effort focuses on the information obtainable from the cores. }\end{array}$ \\
\hline
\end{tabular}


Table 2-2. Object Relationship Model Dictionary. (26 sheets)

\begin{tabular}{|c|c|c|}
\hline Participant name & Ref. \# & Participant description \\
\hline $\begin{array}{l}\text { Data Quality } \\
\text { Objectives }\end{array}$ & 50011 & $\begin{array}{l}\text { DQOS are documents containing qualitative and quantitative statements derived from the DQO } \\
\text { process that clarify study objectives, define the appropriate type of data, and specify the } \\
\text { tolerable levels of potential decision errors that will be used as the basis for establishing the } \\
\text { quantity and quality of data needed to support decisions. The DQOs are based on guidelines } \\
\text { developed by the EPA. Reference material may be found on the Internet DQO Home Page at } \\
\text { the following address: } \\
\qquad h t t p / / \text { terrassa.pnl.gov:2080/DQO/glossary.html. } \\
\text { DQOs pass through multiple states during the development/review process. These states are } \\
\text { shown on the DPM and are as follows: } \\
\text { - Initial draft } \\
\text { - SD draft } \\
\text { - SD revision } \\
\text { - Fecond SD revision } \\
\text { - External review draft } \\
\text { - Approval copy } \\
\text { - Current approved version } \\
\text { Approved version, revision required. }\end{array}$ \\
\hline Digestion Log & 50437 & $\begin{array}{l}\text { The digestion log records the steps in the digestion event plus any observations and deviations } \\
\text { from the procedure. }\end{array}$ \\
\hline
\end{tabular}


Table 2-2. Object Relationship Model Dictionary. (26 sheets)

\begin{tabular}{|c|c|c|}
\hline Participant name & Ref. \# & Participant description \\
\hline DNFSB & 50446 & $\begin{array}{l}\text { The DNFSB is a Congressionally chartered organization that provides technical oversight of } \\
\text { DOE facilities and operations for the elected representatives of the people. } \\
\text { The DNFSB reports directly to the Secretary of the DOE and (if necessary) the President of the } \\
\text { United States. Reports are made to Congress annually and on other occasions when requested } \\
\text { by Congress. DNFSB investigations typically result in "Findings" that are communicated to } \\
\text { DOE and become programmatic drivers, i.e., basis for establishing priorities, funding requests } \\
\text { from Congress. } \\
\text { The DNFSB does not have direct regulatory authority and hence is classified as "society" rather } \\
\text { than "regulator." However, the impact of a negative finding is effectively the same as a } \\
\text { directive from a regulatory agency. DNFSB is one source of requirements for tank } \\
\text { characterization through the findings process. }\end{array}$ \\
\hline DNFSB Finding & 50008 & $\begin{array}{l}\text { (See DNFSB [50540]) A finding is a written report prepared for Congress by the DNFSB. } \\
\text { These reports document the results of DNFSB visits to the Hanford Site and may include } \\
\text { findings about tank farm conditions, operations, etc. }\end{array}$ \\
\hline Doc Prep Resource & 50424 & $\begin{array}{l}\text { These resources are materials used to facilitate the document preparation process, such as } \\
\text { templates. }\end{array}$ \\
\hline Document & 50413 & $\begin{array}{l}\text { A document may be either in hard copy or electronic format. Where the specific type of format } \\
\text { may have an impact on the process being described, the document's specific format is } \\
\text { identified. }\end{array}$ \\
\hline Document Control & 50068 & $\begin{array}{l}\text { Document Control keeps a copy of all controlled manuals and documentation and provides a } \\
\text { mechanism for document revision tracking and control. }\end{array}$ \\
\hline $\begin{array}{l}\text { Document Control } \\
\text { Record }\end{array}$ & 50411 & $\begin{array}{l}\text { This category contains the various records required by the document control and release } \\
\text { processes. }\end{array}$ \\
\hline
\end{tabular}


Table 2-2. Object Relationship Model Dictionary. (26 sheets)

\begin{tabular}{|c|c|c|}
\hline Participant name & Ref. \# & Participant description \\
\hline $\begin{array}{l}\text { DOE Char. } \\
\text { Division Staff }\end{array}$ & 50098 & $\begin{array}{l}\text { The staff members of the DOE Characterization Division represent the owner of the tanks } \\
\text { (DOE). }\end{array}$ \\
\hline $\begin{array}{l}\text { DOE } \\
\text { Characterization } \\
\text { Division }\end{array}$ & 50009 & $\begin{array}{l}\text { The DOE is the owner of record for the Hanford Site and is ultimately responsible for all the } \\
\text { activities at the Site. The DOE typically hires subcontractors to carry out portions of the work, } \\
\text { i.e., major programs, under DOE direction. The Characterization Division is the organization } \\
\text { within DOE concerned with monitoring and controlling the work of tank characterization. }\end{array}$ \\
\hline $\begin{array}{l}\text { DOE Concurrence } \\
\text { cc: Mail }\end{array}$ & 50400 & $\begin{array}{l}\text { Once the DOE Characterization staff and the project coordinator agree on comment resolutions, } \\
\text { the DOE Characterization staff indicate concurrence via cc:Mail. }\end{array}$ \\
\hline DQO Author & 50005 & $\begin{array}{l}\text { The author is the member of the Characterization Technical Basis organization who is assigned } \\
\text { the responsibility for writing a new, or revising an existing, DQO. }\end{array}$ \\
\hline DQO Facilitator & 50007 & $\begin{array}{l}\text { A DQO facilitator is an individual who has received special training and acts as a facilitator in } \\
\text { the stakeholder meetings that are held to write or revise DQOs. This may be a member of the } \\
\text { Characterization Technical Basis organization or a contractor. }\end{array}$ \\
\hline DQO History & 50422 & $\begin{array}{l}\text { This category identifies the various working and review documents that are used in the DQO } \\
\text { development process. }\end{array}$ \\
\hline DQO In Process & 50423 & $\begin{array}{l}\text { DQOs pass through many states before being publicly released. Collectively, these are all } \\
\text { categorized as DQOs in progress (see 50011, Data Quality Objectives). }\end{array}$ \\
\hline Draft TCR Report & 50096 & $\begin{array}{l}\text { The draft TCR is the version prepared by the subcontractor. The draft TCR passes through two } \\
\text { states: initial and drafted. The first represents the initial version prepared by the } \\
\text { subcontractor's organization and the second is the completed, internally reviewed draft ready for } \\
\text { return to the project coordinator. }\end{array}$ \\
\hline Duplicating & 50406 & $\begin{array}{l}\text { Duplicating provides for high-volume duplicating services, e.g., documents for release to large } \\
\text { distribution lists. }\end{array}$ \\
\hline $\begin{array}{l}\text { E-File 45-Day } \\
\text { Report }\end{array}$ & 50070 & See 50415, Electronic Document and 50071, 45-Day Report. \\
\hline
\end{tabular}


Table 2-2. Object Relationship Model Dictionary. (26 sheets)

\begin{tabular}{|c|c|c|}
\hline Participant name & Ref. \# & Participant description \\
\hline $\begin{array}{l}\text { E-File 60-Day } \\
\text { Report }\end{array}$ & 50074 & See 50415, Electronic Document and 50075, 60-Day Report. \\
\hline $\begin{array}{l}\text { E-File 90-Day } \\
\text { Report }\end{array}$ & 50077 & See 50415, Electronic Document and 50080, 90-Day Report. \\
\hline $\begin{array}{l}\text { E-File Final Data } \\
\text { Report }\end{array}$ & 50082 & See 50415, Electronic Document and 50081, Final Data Package. \\
\hline Ecology & 50017 & $\begin{array}{l}\text { Ecology is charged with the enforcement of the State of Washington environmental laws. } \\
\text { Ecology is one of the three signatories to the Tri-Party Agreement which specifies how and } \\
\text { when DOE will bring the Hanford Site into compliance with those laws. Ecology is one source } \\
\text { of requirements for tank characterization through the annual negotiations that update and revise } \\
\text { the Tri-Party Agreement. }\end{array}$ \\
\hline $\begin{array}{l}\text { Electronic } \\
\text { Document }\end{array}$ & 50415 & $\begin{array}{l}\text { This category is used for documents that are issued in electronic form to expedite data } \\
\text { dissemination. Documents in this category are as follows: } \\
\text { - E-File 45-Day Report }(50070) \\
\text { - E-File 60-Day Report }(50074) \\
\text { - E-File 90-Day Report }(50077) \\
\text { E-File Final Data Report }(50082) \text {. }\end{array}$ \\
\hline $\begin{array}{l}\text { Engineering Data } \\
\text { Transmittal }\end{array}$ & 50404 & $\begin{array}{l}\text { The EDT contains documentation of the (WHC internal) transmittal of information, in this } \\
\text { instance the TCR and data reports. The EDT contains specifications of (1) why the data are } \\
\text { transmitted (approval, release, information, review, post-review, and distribution), and (2) the } \\
\text { approvals required for the transmission of the information. }\end{array}$ \\
\hline EPA & 50019 & $\begin{array}{l}\text { The EPA is charged with the enforcement of the federal environmental laws. EPA is one of the } \\
\text { three signatories to the Tri-Party Agreement which specifies how and when DOE will bring the } \\
\text { Hanford Site into compliance with those laws. EPA is one source of requirements for tank } \\
\text { characterization through the annual negotiations that update and revise the Tri-Party Agreement. }\end{array}$ \\
\hline
\end{tabular}


Table 2-2. Object Relationship Model Dictionary. (26 sheets)

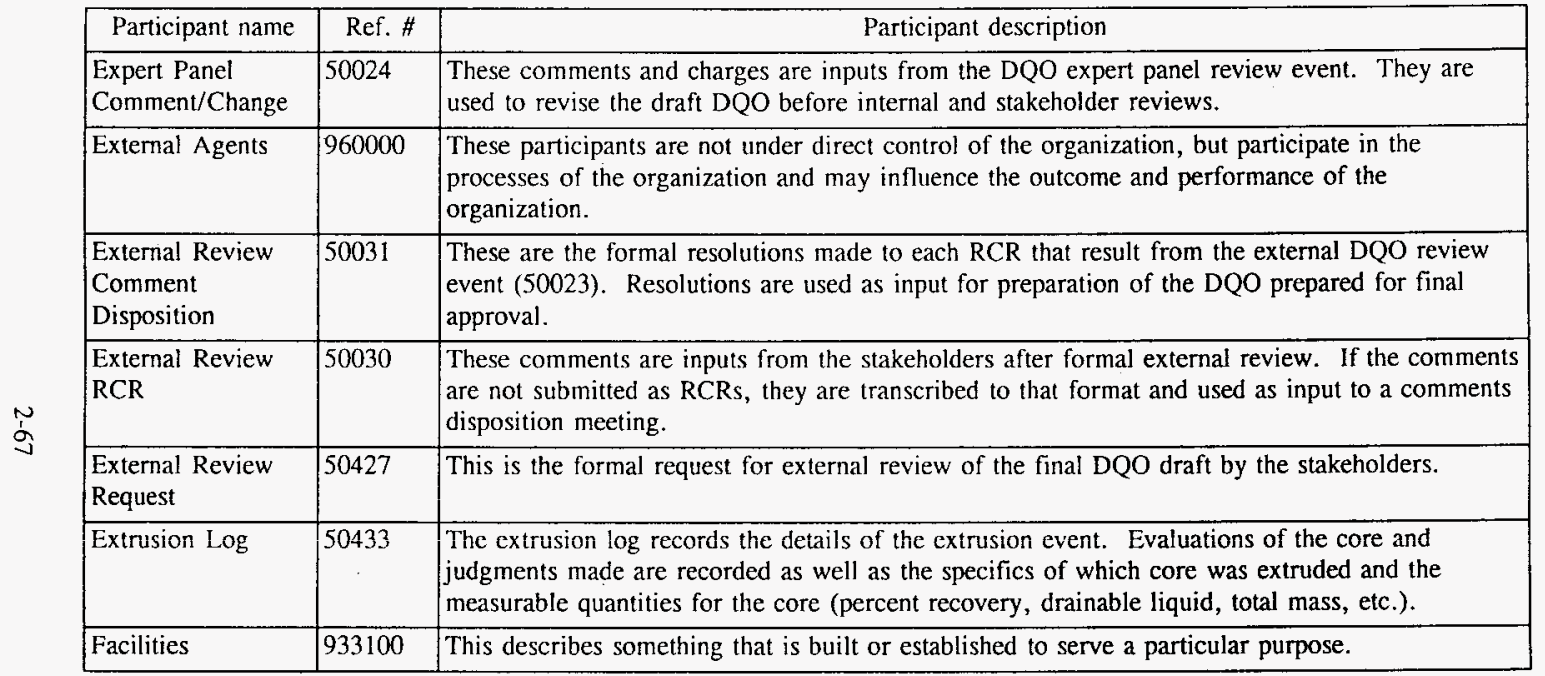


Table 2-2. Object Relationship Model Dictionary. (26 sheets)

\begin{tabular}{|c|c|c|}
\hline Participant name & Ref. \# & Participant description \\
\hline Final Data Package & 50081 & $\begin{array}{l}\text { The final data package, also known as the } 105 \text {-day report, includes the following: } \\
\text { - } 45 \text {-day report } \\
\text { - } 60 \text {-day report (if generated) } \\
\text { - Chain-of-Custody forms } \\
\text { - Description of sampling event (e.g., sampling log) } \\
\text { - Evaluation of the quality and reliability of the data } \\
\text { - Composition data from samples (e.g., elemental and radionuclide concentration levels) } \\
\text { The final data package provides the basis for the preparation/update of the TCR. }\end{array}$ \\
\hline Financial Resources & 932000 & A financial resource is money, funds, or credit that the organization is able to spend. \\
\hline $\begin{array}{l}\text { Hanford Analytical } \\
\text { Services QA Plan }\end{array}$ & 50046 & $\begin{array}{l}\text { Use of this plan in preparing TCPs ensures that the analytical QA requirements will be treated } \\
\text { uniformly in each TCP. }\end{array}$ \\
\hline $\begin{array}{l}\text { Hard Copy } \\
\text { Document }\end{array}$ & 50414 & $\begin{array}{l}\text { These are the various characterization documents that are prepared and released and/or retained } \\
\text { in hard copy form. }\end{array}$ \\
\hline $\begin{array}{l}\text { Historical Tank } \\
\text { Contents Estimate }\end{array}$ & 50034 & $\begin{array}{l}\text { The HTCEs are a priori estimates of the tank contents based on the known operational histories. } \\
\text { A number of modules to the HTCE describe various aspects of the tank contents. The HTCEs } \\
\text { have not been subjected to configuration control, peer review, or documentation of methods } \\
\text { used. The version of the HTCE used in the TCR is at the option of the project coordinator. }\end{array}$ \\
\hline Human Resources & 931000 & $\begin{array}{l}\text { A human resource is defined as the people who perform the business processes of the } \\
\text { organization (e.g., an employee). }\end{array}$ \\
\hline ICF Kaiser & 50090 & ICF KH provides many construction and other services to TWRS. \\
\hline
\end{tabular}


Table 2-2. Object Relationship Model Dictionary. (26 sheets)

\begin{tabular}{|c|c|c|}
\hline Participant name & Ref. \# & Participant description \\
\hline $\begin{array}{l}\text { Information Release } \\
\text { Administration }\end{array}$ & 50067 & $\begin{array}{l}\text { This organization (1) provides review to ensure that classified, business-sensitive, and other } \\
\text { content that affects the release status of a document is properly handled; and (2) clears the } \\
\text { document for either internal or external release. At this time, all unclassified, non-sensitive } \\
\text { documents are cleared for external release unless a special exception is requested. }\end{array}$ \\
\hline $\begin{array}{l}\text { Information Release } \\
\text { Request }\end{array}$ & 50401 & $\begin{array}{l}\text { The IRR identifies the document and describes a number of characteristics of the document, } \\
\text { e.g., document number, type of report, EDT number, title, program, and unclassified category. }\end{array}$ \\
\hline $\begin{array}{l}\text { Information } \\
\text { Resource }\end{array}$ & 934000 & $\begin{array}{l}\text { An information resource is defined in terms of the meaning that people within the organization } \\
\text { assign to data. }\end{array}$ \\
\hline $\begin{array}{l}\text { Information } \\
\text { Technology } \\
\text { Resource }\end{array}$ & 935000 & $\begin{array}{l}\text { This category contains the various information technology resources directly used by the } \\
\text { characterization processes. It should be noted that LABCORE has been classified as } \\
\text { "Custom-Developed Application Software }(936123) \text { " because it has been heavily modified. }\end{array}$ \\
\hline Internal Customer & 50010 & $\begin{array}{l}\text { Internal customers are persons and organizations belonging to the O\&M Contractor } \\
\text { organization. }\end{array}$ \\
\hline $\begin{array}{l}\text { Internal Review } \\
\text { RCR }\end{array}$ & 50060 & $\begin{array}{l}\text { These are inputs from the DQO internal review event. These comments are combined with } \\
\text { inputs received from the stakeholder review and used to revise the draft DQO. }\end{array}$ \\
\hline $\begin{array}{l}\text { Lab Immediate } \\
\text { Notification } \\
\text { Telecon }\end{array}$ & 50065 & $\begin{array}{l}\text { The telecon is a standard record of telephone conversations. In this model the information } \\
\text { recorded is the immediate notification, based on LABCORE data, that a tank parameter has } \\
\text { exceeded a safety limit. }\end{array}$ \\
\hline $\begin{array}{l}\text { Lab Project } \\
\text { Narrative }\end{array}$ & 50435 & $\begin{array}{l}\text { The narrative is a text description of the analyses, the samples, and the results. Any } \\
\text { observations made during the analyses are brought forward and captured here as well. }\end{array}$ \\
\hline Lab QA Approval & 50447 & $\begin{array}{l}\text { QA approval indicates that the applicable QA procedures have been followed and the laboratory } \\
\text { results meet specified quality standards. }\end{array}$ \\
\hline
\end{tabular}


Table 2-2. Object Relationship Model Dictionary. (26 sheets)

\begin{tabular}{|c|c|c|}
\hline Participant name & Ref. \# & Participant description \\
\hline LABCORE & 50062 & $\begin{array}{l}\text { LABCORE is a computer application that manages data for the laboratories. It provides a } \\
\text { database that stores all the onsite laboratory-generated data including those from sample analysis } \\
\text { work. }\end{array}$ \\
\hline $\begin{array}{l}\text { LABCORE Data } \\
\text { File Update }\end{array}$ & 50064 & This is a file consisting of sample analysis data that are used to update the TCD database. \\
\hline $\begin{array}{l}\text { LABCORE Data } \\
\text { Report }\end{array}$ & 50063 & $\begin{array}{l}\text { The LABCORE data report is a hard copy output from LABCORE that documents the } \\
\text { laboratory analysis results. The project coordinator uses the LABCORE data report to prepare } \\
\text { the data reports. }\end{array}$ \\
\hline $\begin{array}{l}\text { LABCORE } \\
\text { Database Entry }\end{array}$ & 50444 & $\begin{array}{l}\text { Each sampling event becomes a project in the LABCORE database. Initially, the first project } \\
\text { setup is performed (in LABCORE) by the project coordinator. The project data are then } \\
\text { updated as information about expected samples and planned analyses is entered. These data } \\
\text { may be modified after sample extrusion when the bench plan is revised, if the samples retrieved } \\
\text { do not meet the expectations of the SAP. During analysis, the LABCORE analysis records are } \\
\text { associated with this project information. }\end{array}$ \\
\hline LABCORE Request & 50052 & $\begin{array}{l}\text { LABCORE requests are entered into LABCORE by the project coordinator to define the } \\
\text { required analysis to be performed on each of the subsamples obtained from the samples. These } \\
\text { requests are stored in the LABCORE database where they are accessed by laboratory personnel } \\
\text { during preparation of the bench plan. }\end{array}$ \\
\hline Laboratory Staff & 50049 & $\begin{array}{l}\text { The laboratory staff analyzes the physical samples received from the sampling crew. They also } \\
\text { provide consultation to the project coordinator in preparing the SAP and interpreting the } \\
\text { laboratory results. }\end{array}$ \\
\hline Lotus $1-2-3^{3}$ & 50444 & This off-the-shelf spreadsheet package is used in analysis and reporting of characterization data. \\
\hline Mail Services & 50095 & $\begin{array}{l}\text { Mail Services distributes mail throughout the Hanford Site. Hard copy documents are generally } \\
\text { released by sending them out through the plant mail. Hard copy information is also generally } \\
\text { exchanged through Mail Services. }\end{array}$ \\
\hline
\end{tabular}


Table 2-2. Object Relationship Model Dictionary. (26 sheets)

\begin{tabular}{|c|c|c|}
\hline Participant name & Ref. \# & Participant description \\
\hline Microsoft EXCEL ${ }^{4}$ & 50443 & This off-the-shelf spreadsheet package is used in analysis and reporting of characterization data. \\
\hline $\begin{array}{l}\text { Multimedia Service } \\
\text { Center }\end{array}$ & 50022 & $\begin{array}{l}\text { This organization provides the services of word processing clerks and technical editors and } \\
\text { assembly of a finished draft that meets the WHC document publication standards. }\end{array}$ \\
\hline $\begin{array}{l}\text { Need for } 45-\text { Day } \\
\text { Report }\end{array}$ & 50428 & $\begin{array}{l}\text { This participant is a process trigger within the "Data Packages Issued" sub-event. It results } \\
\text { from an examination of the SAP and is based on whether any safety-affecting constituents are } \\
\text { expected in the sample. If not, the "Need for 45-Day Report" participant is created. }\end{array}$ \\
\hline $\begin{array}{l}\text { Need for 90-Day } \\
\text { Report }\end{array}$ & 50078 & $\begin{array}{l}\text { This participant is a process trigger within the "Data Packages Issued" sub-event. It results } \\
\text { from a review of the analysis results. The data are compared against several Safety-related } \\
\text { DQOs to determine the safety status of the tank (DSCG, total alpha, ferrocyanide). If a safety } \\
\text { limit is violated, a need for performing a secondary analysis (i.e., 90-day data report) is } \\
\text { generated. }\end{array}$ \\
\hline $\begin{array}{l}\text { Need for } \\
\text { Subcontractor }\end{array}$ & 50407 & $\begin{array}{l}\text { The project coordinator has the option of preparing the TCR directly or using a subcontractor. } \\
\text { The decision or which route produces a need for either a TCR author or a subcontractor. }\end{array}$ \\
\hline $\begin{array}{l}\text { Need for WHC } \\
\text { Author }\end{array}$ & 50408 & $\begin{array}{l}\text { The project coordinator has the option of preparing the TCR directly or using a subcontractor. } \\
\text { The decision or which route produces a need for either a TCR author or a subcontractor. }\end{array}$ \\
\hline $\begin{array}{l}\text { Notification } \\
\text { Internal Memo }\end{array}$ & 50083 & $\begin{array}{l}\text { This memo provides written notification from the project coordinator to the operations and } \\
\text { safety customers that a measured parameter has exceeded a safety limit. This written } \\
\text { notification is required within } 24 \text { hours of the verbal notification by the laboratory staff. }\end{array}$ \\
\hline $\begin{array}{l}\text { Operational Safety } \\
\text { Directive }\end{array}$ & 50092 & $\begin{array}{l}\text { OSDs quantify the safe operating limits for selected tank parameters such as total organics and } \\
\text { flammable gas }\left(\mathrm{H}_{2}\right) \text {. OSDs are derived from the safety analysis reports performed by the Safety } \\
\text { organization. }\end{array}$ \\
\hline
\end{tabular}


Table 2-2. Object Relationship Model Dictionary. (26 sheets)

\begin{tabular}{|c|c|c|}
\hline Participant name & Ref. \# & Participant description \\
\hline Operations Staff & 50056 & $\begin{array}{l}\text { These individuals are knowledgeable in TWRS waste tank and sampling operations, and provide } \\
\text { input to the SAP development process. }\end{array}$ \\
\hline Organization Unit & 943000 & An organizational unit is an organization with its own line of service and resources. \\
\hline Oversight Group & 50540 & $\begin{array}{l}\text { This category includes organizations with oversight authority over the characterization process } \\
\text { and data. }\end{array}$ \\
\hline Owner & 964000 & The owner is the person or organization that is the owner of the assets of the organization. \\
\hline Peer Reviewer & 50025 & $\begin{array}{l}\text { These reviewers are members of the Characterization Technical Basis organization who fulfill } \\
\text { the role of peer reviewer for their fellow group members. }\end{array}$ \\
\hline $\begin{array}{l}\text { Physical } \\
\text { Information } \\
\text { Resource }\end{array}$ & 934200 & This describes tangible information assets such as hardware, software, and documents. \\
\hline Pretreatment & 50417 & $\begin{array}{l}\text { The pretreatment function is responsible for the separation of the recovered waste into high- and } \\
\text { low-level waste streams, then passing each waste stream onto a treatment function specific to } \\
\text { each waste stream, e.g., vitrification. }\end{array}$ \\
\hline $\begin{array}{l}\text { Problem/Issue } \\
\text { Knowledgeable } \\
\text { Person }\end{array}$ & 50012 & $\begin{array}{l}\text { This is an individual who has in-depth knowledge of the problem or issue for which a DQO will } \\
\text { be written. }\end{array}$ \\
\hline Product & 950000 & $\begin{array}{l}\text { Products are entities resulting from activities or processes of the organization. In the } \\
\text { characterization model, this category includes the cores and samples. }\end{array}$ \\
\hline $\begin{array}{l}\text { Production Control } \\
\text { Planner }\end{array}$ & 50440 & This person provides expertise in project planning to work package (50061) development. \\
\hline
\end{tabular}


Table 2-2. Object Relationship Model Dictionary. (26 sheets)

\begin{tabular}{|c|c|c|}
\hline Participant name & Ref. \# & Participant description \\
\hline Project Coordinator & 50033 & $\begin{array}{l}\text { Project coordinators are responsible for the activities related to the characterization of their } \\
\text { assigned tanks. Project coordinators are expected to be the focal point and driver for all tank } \\
\text { characterization activities and the individuals most knowledgeable about the individual tanks for } \\
\text { which they have been assigned responsibility. }\end{array}$ \\
\hline Regulators & 962000 & $\begin{array}{l}\text { There are two regulatory agencies that provide immediate oversight and regulation of the } \\
\text { Hanford Site: Ecology and the EPA. Other regulatory authorities who occasionally have effect } \\
\text { through these regulators are the DOH (in cooperation with Ecology) and the NRC (by reference } \\
\text { from EPA). }\end{array}$ \\
\hline $\begin{array}{l}\text { Request for Expert } \\
\text { Panel Review }\end{array}$ & 50426 & This participant is used as a "trigger" for the expert panel review of the initial draft DQO. \\
\hline Retrieval & 50419 & $\begin{array}{l}\text { This function is responsible for the removal of the characterized wastes from the tanks and } \\
\text { delivery to the appropriate treatment facility. }\end{array}$ \\
\hline SACS Database & 50091 & $\begin{array}{l}\text { The data in the SACS database represent ongoing monitoring, via in situ instruments, of the } \\
\text { tank conditions. Principal data stored are surface levels and temperatures. }\end{array}$ \\
\hline SACS System & 50449 & $\begin{array}{l}\text { The SACS maintains a database that stores data received from the Tank Monitor and Control } \\
\text { System and the Computer-Automated Surveillance System. The data in SACS represent } \\
\text { ongoing monitoring, via in situ instruments, of the tank conditions. Principal data stored are } \\
\text { surface levels and temperatures. }\end{array}$ \\
\hline $\begin{array}{l}\text { Safety Review } \\
\text { Meeting Minutes }\end{array}$ & 50069 & $\begin{array}{l}\text { These minutes document the review of anomalous data, i.e., data that exceed a primary safety } \\
\text { screen. The minutes contain recommendations for changes in the tank safety status and/or } \\
\text { operational controls. }\end{array}$ \\
\hline
\end{tabular}


Table 2-2. Object Relationship Model Dictionary. (26 sheets)

\begin{tabular}{|c|c|c|}
\hline Participant name & Ref. \# & Participant description \\
\hline Sample & 50059 & $\begin{array}{l}\text { Samples exist in several states: } \\
\text { - Core received (sample in core) } \\
\text { - Child } \\
\text { - Archived } \\
\text { Digested. } \\
\text { When removed from the core, the samples are material, solid or liquid. The samples, when } \\
\text { first removed from the core, are the parent samples and consist, collectively, of all the solid } \\
\text { material plus one parent sample for all the drainable liquid. Subsequently, child samples are } \\
\text { created by taking subsamples of a parent or previous child sample. Samples may be stored for } \\
\text { use later in the current analysis sequence or they may be archived for long-term storage, in the } \\
\text { event a reanalysis is required. }\end{array}$ \\
\hline $\begin{array}{l}\text { Sample Analysis } \\
\text { QA Approval }\end{array}$ & 50436 & $\begin{array}{l}\text { QA approval indicates that the applicable QA procedures have been followed and the laboratory } \\
\text { results meet specified quality standards. }\end{array}$ \\
\hline $\begin{array}{l}\text { Sample Analysis } \\
\text { Record }\end{array}$ & 50438 & This category includes all the records created during the sample analysis. \\
\hline $\begin{array}{l}\text { Sampling and } \\
\text { Analysis Plan }\end{array}$ & 50055 & $\begin{array}{l}\text { The SAP describes the subsampling and analytical procedures to be applied to the samples once } \\
\text { they are delivered to the laboratory. The internal customers contribute to the SAP through a } \\
\text { negotiation process. The internal customers also approve the SAP. The project coordinator } \\
\text { must ensure consistency between the work packages and the SAP. }\end{array}$ \\
\hline $\begin{array}{l}\text { Sampling and } \\
\text { Analysis Plan } \\
\text { Template }\end{array}$ & 50058 & $\begin{array}{l}\text { Currently, this is an electronic version of an existing SAP for tanks with similar contents that is } \\
\text { used in the word processing process as "cut and paste" inputs to a new SAP. Work is } \\
\text { underway to use more sophisticated electronic inputs for this resource. }\end{array}$ \\
\hline
\end{tabular}


Table 2-2. Object Relationship Model Dictionary. (26 sheets)

\begin{tabular}{|c|c|c|}
\hline Participant name & Ref. \# & Participant description \\
\hline Sampling Crew & 50050 & $\begin{array}{l}\text { The sampling crew performs the physical tank sampling process and transports the samples to } \\
\text { the laboratory. The sampling crew (or members thereof) provide consultation to the project } \\
\text { coordinator in the preparation of the field instructions for sampling. The sampling crew is } \\
\text { composed of various craft designations and supervisory personnel. This participant is not } \\
\text { further defined at this time. }\end{array}$ \\
\hline $\begin{array}{l}\text { Sampling } \\
\text { Engineering Cog. } \\
\text { Engineer }\end{array}$ & 50054 & $\begin{array}{l}\text { This participant is the cognizant engineer for the sampling event. This engineer shares } \\
\text { responsibility for developing the sampling event work package (50061) with the production } \\
\text { control planner. }\end{array}$ \\
\hline $\begin{array}{l}\text { Sampling Priority } \\
\text { List }\end{array}$ & 50039 & $\begin{array}{l}\text { This is a listing of the tanks to be sampled, in order of priority, that is prepared by the } \\
\text { Characterization Technical Basis organization with input by the TWRS Program elements for } \\
\text { input into the sample scheduling process. }\end{array}$ \\
\hline Sampling Schedule & 50051 & $\begin{array}{l}\text { The sampling schedule reflects the sampling priority list to the extent possible given any existent } \\
\text { scheduling constraints. }\end{array}$ \\
\hline $\begin{array}{l}\text { Sampling Schedule } \\
\text { Change }\end{array}$ & 50057 & $\begin{array}{l}\text { This includes any changes to already scheduled sampling events, e.g., new safety issues, } \\
\text { equipment breakdowns, and priority changes. }\end{array}$ \\
\hline $\begin{array}{l}\text { Scheduling } \\
\text { Constraint }\end{array}$ & 50041 & $\begin{array}{l}\text { In the context of the DPM, this represents anything that limits or affects the scheduling of the } \\
\text { sampling events. Examples include the following: } \\
\text { - Document production capacity } \\
\text { - Tanker health and safety constraints } \\
\text { - Sampling team personnel and equipment availability } \\
\text { - Sample analysis capacity } \\
\text { - Tank location. }\end{array}$ \\
\hline
\end{tabular}


Table 2-2. Object Relationship Model Dictionary. (26 sheets)

\begin{tabular}{|c|c|c|}
\hline Participant name & Ref. \# & Participant description \\
\hline SD Cover Sheet & 50403 & $\begin{array}{l}\text { The } S D \text { Cover Sheet identifies the document, provides an abstract, and displays a stamp with the } \\
\text { release date indicating that the document has been approved for release. Document Control } \\
\text { provides the approval stamp, and the project coordinator is responsible for completing the } \\
\text { balance of the form. }\end{array}$ \\
\hline Shipping Cask & 50445 & $\begin{array}{l}\text { As the cores are retrieved from the tank being sampled, they are placed inside a shipping cask } \\
\text { for safe transport to the laboratory. }\end{array}$ \\
\hline Signature Page & 50032 & $\begin{array}{l}\text { This is a sheet prepared for obtaining RL and Ecology concurrence on the final DQO before } \\
\text { release. }\end{array}$ \\
\hline Stakeholder & 50421 & $\begin{array}{l}\text { The category of stakeholders, as used in this model, represents those external entities that are } \\
\text { TWRS customers, i.e., those with a direct influence in TWRS operations. These include the } \\
\text { RL Characterization Division and EPA, Ecology, and other regulators. }\end{array}$ \\
\hline $\begin{array}{l}\text { Stakeholder } \\
\text { Comment, Issue } \\
\text {-1st Mtg. }\end{array}$ & 50021 & This is input to the DQO authoring process as developed in the initial stakeholder meeting. \\
\hline $\begin{array}{l}\text { Stakeholder Input } \\
\text { Requirement }\end{array}$ & 50425 & $\begin{array}{l}\text { This represents the need for early stakeholder input into the DQO development or revision } \\
\text { process. }\end{array}$ \\
\hline $\begin{array}{l}\text { Stakeholder Point } \\
\text { of View }\end{array}$ & 50016 & This represents stakeholder inputs and positions during DQO review processes. \\
\hline $\begin{array}{l}\text { Stakeholder Review } \\
\text { Comment - RCR }\end{array}$ & 50029 & $\begin{array}{l}\text { These results of the stakeholder review of the draft DQO document are prepared after the initial } \\
\text { stakeholder meeting. These may or may not be submitted as formal RCRs. They are combined } \\
\text { with the RCRs from the external review event ( } 50023) \text { and used to revise the DQO draft. }\end{array}$ \\
\hline Strawman DQO & 50015 & $\begin{array}{l}\text { This is a preliminary, rough draft of a DQO that is developed as a template for use in the initial } \\
\text { stakeholder meeting to focus attention. If the purpose of the meeting is to revise an existing } \\
\text { DQO, the current version serves as the strawman. }\end{array}$ \\
\hline
\end{tabular}


Table 2-2. Object Relationship Model Dictionary. (26 sheets)

\begin{tabular}{|c|c|c|}
\hline Participant name & Ref. \# & Participant description \\
\hline Subcontractor & 50094 & $\begin{array}{l}\text { Subcontractors are used to prepare portions or complete drafts of the TCR as well as other } \\
\text { documents, e.g., data reports. }\end{array}$ \\
\hline $\begin{array}{l}\text { Subject Matter } \\
\text { Expert }\end{array}$ & 50020 & $\begin{array}{l}\text { These individuals are brought into the process of creating various documents to provide in-depth } \\
\text { knowledge. Examples include laboratory personnel, samplers, statisticians, etc. }\end{array}$ \\
\hline Supplier & 961000 & $\begin{array}{l}\text { Participants in this category are external agents who provide resources or services to the } \\
\text { organization. }\end{array}$ \\
\hline $\begin{array}{l}\text { Surveillance } \\
\text { Information }\end{array}$ & 50042 & $\begin{array}{l}\text { This information from normal and special tank surveillance activities provides additional inputs } \\
\text { to the TCP and SAP preparation activities. }\end{array}$ \\
\hline Tank & 50002 & $\begin{array}{l}\text { Tanks store high-level waste from previous Hanford Site operations. The tanks are sited in } \\
\text { controlled access areas called tank farms. The tanks are underground and accessible through } \\
\text { risers. Tanks are also connected to other tanks and to facilities external to the tank farms } \\
\text { through process piping. A tank may be either single or double shell. The tank operational } \\
\text { states may be active, inactive, or isolated. The tank may be listed on one or more Watchlists } \\
\text { depending on the current estimates of the tank contents: ferrocyanide, flammable gas, organics, } \\
\text { leaker, or high heat. In this model, the tank characterization status may be as follows: } \\
\text { - Characterization required } \\
\text { - Sampled (sample extracted but the TCR has not been released) } \\
\text { - Characterized (TCR released and no further sampling events are identified for } \\
\text { characterization purposes). }\end{array}$ \\
\hline $\begin{array}{l}\text { Tank Char. } \\
\text { Resource Center }\end{array}$ & 50087 & $\begin{array}{l}\text { The TCRC is a facility for the collection of hard copy information relevant to tank } \\
\text { characterization efforts. The information is stored by tank. Within each file (box), the } \\
\text { information is in random order. }\end{array}$ \\
\hline
\end{tabular}


Table 2-2. Object Relationship Model Dictionary. (26 sheets)

\begin{tabular}{|c|c|c|}
\hline Participant name & Ref. \# & Participant description \\
\hline $\begin{array}{l}\text { Tank Charact. } \\
\text { Database }\end{array}$ & 50084 & $\begin{array}{l}\text { The TCD has been designated as the ultimate repository of all tank characterization data. There } \\
\text { is a direct electronic connection from LABCORE to the TCD. Access to TCD is through the } \\
\text { Tank Waste Information Network System. This access route is not used by the project } \\
\text { coordinators. }\end{array}$ \\
\hline $\begin{array}{l}\text { Tank } \\
\text { Characterization } \\
\text { Plan }\end{array}$ & 50047 & $\begin{array}{l}\text { The TCP is prepared using the various sources of characterization requirements. The TCP } \\
\text { consolidates the different, and sometimes conflicting, sampling requirements into a single source } \\
\text { document that identifies what information is to be obtained from a set of tank samples. The } \\
\text { TCP provides the basis for the development of the SAP and the work packages. Direct orders } \\
\text { are typically not included in the TCP but are incorporated directly in the SAP and work } \\
\text { packages. }\end{array}$ \\
\hline $\begin{array}{l}\text { Tank } \\
\text { Characterization } \\
\text { Plan Template }\end{array}$ & 50037 & $\begin{array}{l}\text { Currently, this is an electronic version of an existing TCP for tanks with similar contents that is } \\
\text { used in the word processing process as "cut and paste" inputs to a new TCP. Work is } \\
\text { underway to use more sophisticated electronic inputs for this resource. }\end{array}$ \\
\hline
\end{tabular}


Table 2-2. Object Relationship Model Dictionary. (26 sheets)

\begin{tabular}{|c|c|c|}
\hline Participant name & Ref. \# & Participant description \\
\hline $\begin{array}{l}\text { Tank } \\
\text { Characterization } \\
\text { Report }\end{array}$ & 50088 & $\begin{array}{l}\text { The TCR contains the following: } \\
\text { - An executive summary } \\
\text { - Introductory chapter } \\
\text { - Tank operational history } \\
\text { - Dummary of prior sampling and data } \\
\text { - Comparison of the data to various action levels } \\
\text { - Calculation of total inventory and tank average concentrations } \\
\text { - Quality assessment of the data } \\
\text { - Recommendations for changes in tank status, e.g., add/remove from specific Watchlists } \\
\text { A generic TCR table of contents is included in Section } 5.0 \text { of WHC-SD-WM-PD-045.' The } \\
\text { specific contents of the report are flexible depending on the requested sampling and quality and } \\
\text { quantity of data that result. A significant portion of the data analysis methods is judgment } \\
\text { based as to the specifics of any calculations. } \\
\text { The states of a TCR are as follows: } \\
\text { - Drafted } \\
\text { - Technically reviewed } \\
\text { - Reviews completed. }\end{array}$ \\
\hline $\begin{array}{l}\text { Tank Safety } \\
\text { Review Committee }\end{array}$ & 50086 & $\begin{array}{l}\text { This committee meets to conduct a review when sample analysis data show analyte conditions } \\
\text { that exceed specified thresholds. }\end{array}$ \\
\hline
\end{tabular}


Table 2-2. Object Relationship Model Dictionary. (26 sheets)

\begin{tabular}{|c|c|c|}
\hline Participant name & Ref. \# & Participant description \\
\hline $\begin{array}{l}\text { Tank Waste } \\
\text { Analysis Plan }\end{array}$ & 50035 & $\begin{array}{l}\text { The TWAP is primarily a schedule for the sampling of the tanks. The sampling schedule } \\
\text { describes the time line for which, and when, tanks get sampled. It is subject to frequent } \\
\text { revision depending on changing sampling requirements, availability of sampling equipment and } \\
\text { crews, and delays due to problems encountered in the field. }\end{array}$ \\
\hline $\begin{array}{l}\text { Tank Waste Data } \\
\text { Need }\end{array}$ & 50006 & $\begin{array}{l}\text { This is a generic term for any need to derive information about tank waste to support a } \\
\text { decision. This participant triggers the creation or revision of one or more DQOs. }\end{array}$ \\
\hline TCD System & 50448 & The TCD System is the computer application that maintains the TCD. \\
\hline TCD Support & 50085 & $\begin{array}{l}\text { These individuals are from several different organizations and are involved in the process of } \\
\text { updating the TCD. }\end{array}$ \\
\hline TCP Requirement & 50418 & $\begin{array}{l}\text { This trigger results either from tanks being identified for a sampling event in the TWAP or } \\
\text { because of some extraordinary requirement for sampling. Each tank sampling event is required } \\
\text { to have a TCP. }\end{array}$ \\
\hline TCR History & 50412 & $\begin{array}{l}\text { The TCR history category consists of the various documents that are used in the TCR } \\
\text { development process. }\end{array}$ \\
\hline TCR In Process & 50410 & $\begin{array}{l}\text { TCRs pass through many states before being publicly released. Collectively, these are all } \\
\text { categorized as TCRs in progress. }\end{array}$ \\
\hline TCR Manager & 50402 & $\begin{array}{l}\text { The TCR manager is (among other duties) responsible for the management of the TCR } \\
\text { generation process and the project coordinators who prepare the TCRs. In the current context, } \\
\text { this role is fulfilled by the manager of the Characterization Technical Basis organization. }\end{array}$ \\
\hline TCR Markup & 50093 & $\begin{array}{l}\text { TCR markups may be generated by reviewers of the various draft versions of the TCR. The } \\
\text { markup is the means of communicating comments about the draft TCR between the reviewer } \\
\text { and the project coordinator. }\end{array}$ \\
\hline
\end{tabular}


Table 2-2. Object Relationship Model Dictionary. (26 sheets)

\begin{tabular}{|c|c|c|}
\hline Participant name & Ref. \# & Participant description \\
\hline TCR Package & 50405 & $\begin{array}{l}\text { The TCR package contains the TCR, the IRR, the SD release page, and the EDT. The states } \\
\text { of the TCR package are as follows: } \\
\text { - Assembled } \\
\text { Copied } \\
\text { Duplicated } \\
\text { Delivered } \\
\text { The assembled state is when the elements of the TCR package are brought together. The copied } \\
\text { state occurs when time is critical in delivering the "official copy" to DOE to meet a milestone } \\
\text { date for publication. The duplicated state occurs when the document is mass reproduced. The } \\
\text { delivered state occurs when the document is mailed to those on the distribution list. When the } \\
\text { document is released, it goes throung a formal information release system. }\end{array}$ \\
\hline Technical Expert & 50023 & $\begin{array}{l}\text { This participant is a member of a panel selected for specific technical knowledge. This panel } \\
\text { reviews a specific draft DQO before it is sent to internal reviewers. The experts may be } \\
\text { internal personnel or consultants. }\end{array}$ \\
\hline $\begin{array}{l}\text { Technical } \\
\text { Publications }\end{array}$ & 50066 & $\begin{array}{l}\text { This is an old name for the part of a Media Service Center that provides the services of word } \\
\text { processing clerks and technical editors and assembly of a finished draft that meets the WHC } \\
\text { document publication standards. This name is still in common use. }\end{array}$ \\
\hline $\begin{array}{l}\text { TPA Milestone } \\
\text { M-44-00 }\end{array}$ & 50040 & $\begin{array}{l}\text { This is the specific Tri-Party Agreement milestone requiring characterization of } 177 \text { Hanford } \\
\text { Site waste tanks by September } 30,1999 \text {. The milestone requires offsite access to "electronic } \\
\text { database(s) containing tank characterization information." Subordinate milestones state } \\
\text { requirements for an annual TWAP and set annual goals for tank characterizations to be } \\
\text { completed. }\end{array}$ \\
\hline
\end{tabular}


Table 2-2. Object Relationship Model Dictionary. (26 sheets)

\begin{tabular}{|l|l|l|}
\hline Participant name & Ref. \# & \multicolumn{1}{|c|}{ Participant description } \\
\hline $\begin{array}{l}\text { Tri-Party } \\
\text { Agreement }\end{array}$ & 50001 & $\begin{array}{l}\text { The formal name for this document is the Hanford Federal Facility Agreement and Consent } \\
\text { Order. }{ }^{6} \text { This is the formal agreement among EPA, Ecology, and DOE that establishes the } \\
\text { priorities for the Hanford Site remediation effort. The Tri-Party Agreement specifies (among } \\
\text { other things) the number of tanks to be characterized in each fiscal year and mandates the } \\
\text { minimum content of a TCR. }\end{array}$ \\
\hline $\begin{array}{l}\text { TWRS Char. } \\
\text { Program QA Plan }\end{array}$ & 50045 & $\begin{array}{l}\text { QA program plans identify each respective program's requirements and provide implementation } \\
\text { guidance for all activities of that program. These must satisfy the requirements of } \\
\text { WHC-CM-4-27 for a QA program plan. The Characterization Program QA plan provides } \\
\text { implementation guidance for the data customers and an unambiguous source document for use in } \\
\text { preparing TCPs. }\end{array}$ \\
\hline $\begin{array}{l}\text { TWRS } \\
\text { Management }\end{array}$ & 50028 & $\begin{array}{l}\text { This participant is a collective role consisting of the TWRS managers involved in } \\
\text { characterization oversight, document approvals, etc. In the characterization DPM, the managers } \\
\text { are identified as taking part in the general internal review of new and revised DQOs. }\end{array}$ \\
\hline $\begin{array}{l}\text { TWRS Operations } \\
\text { and Maintenance }\end{array}$ & 50416 & $\begin{array}{l}\text { Operations is responsible for the day-to-day functioning of the tank farms. Safe operation } \\
\text { requires knowledge of the current in-tank conditions to establish the safe operating envelope for } \\
\text { tank access. }\end{array}$ \\
\hline $\begin{array}{l}\text { TWRS Program } \\
\text { Data Needs and } \\
\text { Priorities }\end{array}$ & 50038 & $\begin{array}{l}\text { This participant represents the concerns of the TWRS programs that are used to develop } \\
\text { sampling priorities and schedules. }\end{array}$ \\
\hline
\end{tabular}


Table 2-2. Object Relationship Model Dictionary. (26 sheets)

\begin{tabular}{|c|c|c|}
\hline Participant name & Ref. \# & Participant description \\
\hline $\begin{array}{l}\text { TWRS Program } \\
\text { Element }\end{array}$ & 50053 & $\begin{array}{l}\text { This is a collective category and represents any of the II TWRS Program elements that have } \\
\text { needs resulting in DQOS. Presently, only seven of these have such data needs. They are as } \\
\text { follows: } \\
\text { - Waste Tank Safety Program } \\
\text { - High-Level Waste Disposal } \\
\text { - Low-Level Waste Disposal } \\
\text { - Waste Pretreatment } \\
\text { - Taste Retrieval } \\
\text { - Tank Farm O\&M } \\
\text { Tarm Upgrades. }\end{array}$ \\
\hline $\begin{array}{l}\text { TWRS Program } \\
\text { Element Manager }\end{array}$ & 50013 & $\begin{array}{l}\text { This participant is the manager (or delegate) of a specific TWRS Program element. These } \\
\text { persons take ownership of the DQOs associated with their program elements and interface with } \\
\text { the external stakeholders during DQO development. }\end{array}$ \\
\hline $\begin{array}{l}\text { TWRS Safety and } \\
\text { Technical } \\
\text { Integration }\end{array}$ & 50027 & $\begin{array}{l}\text { The Safety organization is (among other duties) responsible for determining the safe operating } \\
\text { conditions of the tanks. These conditions are established through the safety analysis reports } \\
\text { from which OSDs are derived. }\end{array}$ \\
\hline $\begin{array}{l}\text { Wash. Dept. of } \\
\text { Health }\end{array}$ & 50018 & $\begin{array}{l}\text { This agency is sometimes involved in the DQO process when health matters may be impacted. } \\
\text { It also exercises other oversight where state health laws are impacted. }\end{array}$ \\
\hline Watchlist & 50420 & $\begin{array}{l}\text { There are several Watchlists, each for a specific hazardous condition of the tank: ferrocyanide, } \\
\text { flammable gas, organics, leaker, or high heat. The presence of a tank on a Watchlist invokes } \\
\text { operational constraints on access to, and monitoring of, the tank. }\end{array}$ \\
\hline WHC QA & 50026 & WHC QA provides overall QA standards and oversight. \\
\hline Word Perfect ${ }^{8}$ & 50441 & This off-the-shelf word processing software is used to prepare sampling reports, memos, etc. \\
\hline
\end{tabular}


Table 2-2. Object Relationship Model Dictionary. (26 sheets)

\begin{tabular}{|l|l|l|}
\hline Participant name & Ref. \# & \multicolumn{1}{|c|}{ Participant description } \\
\hline Work Package & 50061 & $\begin{array}{l}\text { The work package is a composite document, prepared for each sampling event, that provides the } \\
\text { specific field instructions required for the sampling crew to perform their work. Primary } \\
\text { information contained in the work packages includes tank to be sampled, risers in which to } \\
\text { sample, types of samples required, sampling methods to be used, and intervals to be sampled. } \\
\text { The project coordinator must ensure consistency between the work packages and the SAP. }\end{array}$ \\
\hline Work List & 50043 & $\begin{array}{l}\text { Work lists are generated from LABCORE and go to each instrument or process (e.g., } \\
\text { digestion). The purpose of the work list is to specify how the samples will be batch processed, } \\
\text { e.g., which samples in which order. }\end{array}$ \\
\hline
\end{tabular}

${ }^{1}$ Quattro Pro is a trademark of Borland International, Inc.

${ }^{2} \mathrm{cc}$ : Mail is a trademark of cc:Mail, Inc.

$\sim \quad{ }^{3}$ Lotus $1-2-3$ is a trademark of the Lotus Development Corporation.

${ }_{t}^{4} \mathrm{EXCEL}$ is a trademark of the Microsoft Corporation.

${ }^{5}$ Legore, T., 1996, Tank Waste Remediation System Infornation Systems Definition Tank Characterization Report.

Generation Process As-ls, WHC-SD-WM-PD-045, Rev. 0, Westinghouse Hanford Company, Richland, Washington.

${ }^{6}$ Ecology, EPA, and DOE, 1994, Hanford Federal Facility Agreement and Consent Order, as amended, Washington State

Department of Ecology, U.S. Environmental Protection Agency, and U.S. Department of Energy, Olympia, Washington.

${ }^{7}$ WHC-CM-4-2, Quality Assurance Mamual, Westinghouse Hanford Company, Richland, Washington.

${ }^{8}$ WordPerfect is a trademark of the WordPerfect Corporation. 
Table 2-2. Object Relationship Model Dictionary. (26 sheets)

\begin{tabular}{|c|c|c|c|c|c|}
\hline \multicolumn{2}{|c|}{ Participant name } & Ref. \# & \multicolumn{3}{|c|}{ Participant description } \\
\hline $\mathrm{ACE}$ & $=$ & Analytical Card Enhancement & O\&M & $=$ & Operations and Maintenance \\
\hline $\mathrm{COC}$ & $=$ & Chain-of-Custody & OSD & $=$ & Operational safety directive \\
\hline DNFSB & $=$ & Defense Nuclear Facilities Safety Board & QA & $=$ & Quality Assurance \\
\hline DOE & $=$ & U.S. Department of Energy & $\mathrm{RCR}$ & $=$ & Review Comment Record \\
\hline $\mathrm{DOH}$ & $=$ & Washington State Department of Health & RL & $=$ & U.S. Department of Energy, Richland \\
\hline DPM & $=$ & Dynamic process model & & & Operations Office \\
\hline DQO & $=$ & Data quality objective & SACS & $=$ & Surveillance Analysis Computer System \\
\hline DSC & $=$ & Differential scanning calorimeter & SAP & $=$ & Sampling and analysis plan \\
\hline DSCG & $=$ & Differential scanning calorimeter graph & $\mathrm{SD}$ & $=$ & Supporting document \\
\hline Ecology & $=$ & Washington State Department of & TCD & $=$ & Tank Characterization Database \\
\hline & & Ecology & $\mathrm{TCP}$ & $=$ & Tank characterization plan \\
\hline EDT & $=$ & Engineering Data Transmittal & TCR & $=$ & Tank characterization report \\
\hline EPA & $=$ & U.S. Environmental Protection Agency & TCRC & $=$ & Tank characterization resource center \\
\hline HTCE & $=$ & Historical tank contents estimate & TGA & $=$ & Thermo-gravimetric analysis \\
\hline ICF KH & $=$ & ICF Kaiser Hanford Company & TWAP & $=$ & Tank waste analysis plan \\
\hline IRR & $=$ & Information Release Request & TWRS & $=$ & Tank Waste Remediation System \\
\hline NRC & $=$ & U.S. Nuclear Regulatory Commission & WHC & $=$ & Westinghouse Hanford Company \\
\hline
\end{tabular}


WHC-SD-WM-PD-048 REV 0

This page intentionally left blank. 


\subsection{TECHNICAL INTEGRATION}

\subsection{EXECUTIVE SUMMARY}

The TWRS Program strategy integrates waste operations, safety issue resolution, retrieval, pretreatment, immobilization, and waste disposal. To accomplish this strategy, TWRS is using a combined program and technical management approach to develop an integrated baseline that combines the cost, schedule, and technical baseline for remediating the tank waste.

\subsubsection{Overview}

Systems engineering is the approach selected by the DOE to establish and maintain the TWRS Program baseline over the life of the program. The responsibility and authority for formulating the TWRS SE program have been delegated to RL by DOE-Headquarters (DOE-HQ). The RL TWRS Program Office has assigned the Tank Waste, Retrieval, Treatment, and Immobilization Division as the oversight authority to monitor, assess, and ensure the adequacy of the TWRS program SE activities. It has established TWRS SE policy for implementation by the M\&O Contractor, WHC.

As the Design Authority, WHC has primary responsibility and authority for executing the TWRS Program for RL. The execution of the TWRS Program will include implementing the SE activities. Westinghouse Hanford Company will also identify the TWRS Program technology needs. The WHC vice president for TWRS has assigned the TWRS Safety and Technical Integration organization the responsibility to direct and review TWRS Program technical integration activities using SE processes and technical management techniques. Part of this responsibility includes development and management of the TWRS technical baseline.

The technical baseline is the reference set of technical data. It contains all technical requirements, architectures, and interfaces generated using the SE process (see Section 4.0) to satisfy the TWRS mission need. The technical baseline is given different names as it matures to reflect its evolution from project definition and strategy through the completion of projects.

The baselines are as follows:

- Functional requirements

- Technical requirements

- Design requirements

- Design configuration

- As-built configuration

- Operational

- Decontamination and decommissioning (D\&D). 
The DPM for Technical Integration (Section 3.2) details the first three baselines: functional requirements, technical requirements, and design requirements.

Systems engineering is an iterative process. This means that the process will repeat its full cycle one or more times before a set of deliverables is produced. The deliverables that are produced for each baseline reflect a new level of understanding by persons performing the analysis and engineering. As more information is developed, old deliverables are updated where appropriate and new deliverables are produced. Before the baseline is updated, independent technical reviews are conducted to assess the development of the integrated baseline. Reviews are used to verify conformance with system requirements at the WHC TWRS Program level and with design requirements or specifications at the WHC TWRS Project level. Technical reviews provide data for DOE-HQ and RL Key Decisions.

There are nine baseline reviews: the system requirements review (SRR), the technical requirements review (TRR), the design requirements review (DRR), the system design review (SDR), the preliminary design review (PDR), the definitive design review (DDR), the operations readiness review (ORR), the decontamination and decommissioning review (D\&DR), and mission complete review (MCR).

Each independent review must be successfully completed before a baseline deliverable can be released and before the next baseline phase can be started. For example, successful completion of the TRR is required before the technical requirements specification (TRS) document can be released and its contents used in the further development of the design requirements baseline.

The organizers and participants of the baseline reviews will vary from review to review. For example, the SRR will be organized by a WHC TWRS Program-level organization while the DDR will be organized by a Project. Program stakeholders will participate in reviews, as required, to ensure the consistency and technical adequacy of the evolving TWRS technical baseline. Participation by RL will depend on the baseline being approved.

\subsubsection{Significant Problems/Gaps}

This section focuses on the major information management issues identified during the 1SD effort. The TWRS Technical Integration organization has been tasked with establishing the technical baseline for all of TWRS and to instill SE concepts in the various TWRS projects, operations, and support organizations. One of the strategies for accomplishing these tasks has been to develop information access and management tools that would make work easier for users in the field. A by-product of providing these tools would be the ability to capture data necessary to support the SE process, and maintain a controlled information baseline to support the technical basis. This approach has been met with limited success due to the following factors within TWRS. 
- Projectization of the Hanford Site--Recent projectization of activities at the Hanford Site has shifted the management focus to very specific performance objectives within each project. This approach has yielded many highly publicized successes. However, integration activities such as IM and SE have often been impacted by the urgency to accomplish near-term project-specific milestones. Coincidentally, the development of project-specific information management capabilities instead of shared program-wide capabilities is often the rule rather than the exception. This tendency often results in redundant efforts and inconsistent data.

- Ownership of TWRS Technical Information--The Technical Integration organization establishes and maintains the technical baseline data. However, it currently lacks control over changes to technical data that support much of the technical basis. Projects that generate the technical data used in the decision and risk analysis processes are typically in control of the data's gathering, generation, configuration management, and dissemination. Data traceability and pedigree are often difficult to construct, making decisions less defensible.

- Establishment of Source Data Systems--There are more than 106 information systems currently defined within TWRS. Many of these systems contain duplicate information. The "official" sources for various information types have not been defined. Without this definition, the selection of which data to use for development of the technical baseline is left to the individuals doing the analysis. This can result in inconsistent and sometimes conflicting results.

- Future Organizational Changes--The M\&O Contractor role will be replaced by a PHMC whose primary focus will be to integrate the activities of private contractors tasked with accomplishing portions of the tank waste remediation activities. The design of the information systems infrastructure can be significantly influenced by the winning candidate's management and/or SE approach.

\subsubsection{Next Steps/Recommendations}

The following initiatives are recommended to address the issues described in Section 3.1.2.

- Projectize IM--A TWRS organization needs to be established that is given authority to manage and integrate technical information among projects and at the TWRS Program level. This need has always been recognized in the business/program management area, but now needs to be extended to the technical baseline as well. This organization should be the custodian for the technical information, and establish specific "owners" of the data within the appropriate projects. 
- Define a TWRS Information Network--The TWRS organization defined in the previous paragraph should sponsor the definition of a TWRS information network. This "TWRS*NET" would provide access to key technical information that was controlled and of known quality. It could be created using existing Internet technologies which would enable access by more than $80 \%$ of the current Hanford Site workforce, and controlled offsite access where needed. Existing TWRS Internet information would be assimilated and organized to give a common access path to all TWRS data. Project owners of the data would be assigned to manage the information contained on the TWRS*NET. The TWRS*NET would complement existing software tools by providing a generalized access means to the same databases to ensure data consistency. As new data sources are added to the TWRS*NET, they would be assessed to determine data quality, pedigree, and configuration control criteria. The TWRS*NET would evolve to be the primary interface to TWRS information.

\subsection{DPM}

Figure 3-1 describes the overall SE process for the Technical Integration organization. Figure 3-2 describes the detailed events and participants that make up the initial stages of the process to create the design requirements document (DRD). The following is a brief description of the SE process as modeled in the DPM.

\subsubsection{Mission Analyzed}

Mission analysis translates the mission needs and objectives, customer desires, and other inputs, such as the value system, into mission requirements. The mission or problem to be solved must be traceable to a documented customer need. The information contained in the mission analysis report will be placed under configuration control as part of the TWRS technical baseline and is the initial input for the baseline system description (BSD). Mission analysis forms the basis for the next step in the SE process, which is functions and requirements (F\&R) analysis and allocation.

\subsubsection{F\&R Analyzed}

Functions and requirements analyses and allocation breaks down complex systems into simpler related parts. The result is a framework of functions, constrained by applicable requirements, to satisfy the mission. Existing architectures and initial conditions are used as inputs to this process. 
The TWRS performs functional analysis to decompose the mission into a hierarchy of functions that are necessary and sufficient to satisfy the mission. The functional analysis is documented in a functional hierarchy, function flow block diagrams, and descriptions of the functions and functional interfaces.

The TWRS performs three basic requirements analysis activities: (1) requirements identification and development, (2) requirements validation, and (3) requirements allocation. The first activity identifies constraints, interface requirements, and performance requirements from the three categories as explained below. After identification and development, performance requirements are then validated by simulations, modeling, or analysis to ensure they will satisfy the mission need. Requirements are then allocated to the applicable functions, interfaces, and architectures.

All information associated with functional analysis and requirements analysis will be entered into the RDD-100 database which supports the Requirements Management and Assured Compliance System (RMACS). This system is the central repository for all F\&R, architectures, and supporting data. It generates specifications and test requirements and provides top-to-bottom traceability of functions, requirements, architectures, and components. The RMACS will also be used to track requirements and analyze the impact of functional and requirement changes.

\subsubsection{Alternatives Generated}

Alternative generation and analysis (AGA) is used to identify and analyze alternative system configurations that satisfy mission analysis and technical baseline F\&R. All reasonable alternative architectural concepts are screened against the F\&R. Those that satisfy all requirements are candidates for further analysis and decision making. When existing systems are an alternative, the system will be assessed against the requirements, all deficiencies will be identified, and the resources required to modify the system will be estimated for use in evaluation and optimization activities.

The architecture, in the form of selected engineering data, requirements, and specifications, will form the basis for the technical baseline, and then be formalized through internal and external reviews and controlled using the controlled manual process. The architecture will start as concepts and strategies at the upper levels (e.g., functional requirements baseline), and mature into greater detail at lower levels (e.g., design requirements baseline). This process continues until an architectural element can be obtained as a single unit by subcontracting, purchasing, constructing, writing unit level software, etc.

To focus the design efforts, a BSD document is produced and maintained. The BSD document provides summary text and illustrations of the architectural concepts of the TWRS Program and becomes part of the technical baseline. The BSD will mature as the architecture matures. The architecture selection and decision management activities will be captured in the RMACS to provide a traceable basis for the TWRS Program. 


\subsubsection{Alternatives Evaluated and Optimized}

The evaluation and optimization process provides the main feedback mechanism for the $S E$ process and facilitates the development of a balanced, optimized design solution. Typically, there are numerous considerations in selecting an optimum system and the evaluation and optimization process ensures that no single characteristic dominates the design.

Engineering trade studies are performed during all phases of the program and project life cycles, whenever there is a need to select from two or more options. Trade-offs are conducted among architectures, as well as the following: (1) requirements; (2) engineering designs; (3) project schedule and budget; (4) cost effectiveness; (5) technical, programmatic, environmental, safety, and health risks; and (6) other significant factors. Numerical computer models are one of the key tools used in the alternatives evaluation and optimization process.

\subsubsection{Architecture Selected}

The basic design objective is to optimize the development of a system that will do the best job at the lowest cost. Based on the supporting technical documentation and analysis results, an architecture is selected and reflected in design documents that are formally reviewed.

\subsubsection{Test and Evaluation (T\&E)}

Test and evaluation is the TWRS activity that will verify that the completed system meets the customer's requirements. Performance requirements will be different for components, subsystems, and systems, but are the inputs for each level of the T\&E activity. The determination of the methodology to verify that the system, and its sub-elements, satisfies its performance requirements is an integral step in the SE process.

The specific T\&E method for verification will be determined as the F\&R and architectures are developed to ensure that the performance requirements can be met.

The specific method to be used for requirements verification depends on various factors including cost of verification, importance of requirements, optimum system measurement point, and schedule constraints. 


\subsubsection{RDD-100 Updated}

RDD-100 is the computer system that contains the technical baseline information. It is the major automated component of the RMACS. RDD-100 is updated anytime there is an approved change to the F\&R or architecture information.

A key component of the DPM is the update mechanism for RDD-100. An update process for RDD-100 is triggered anywhere there is a need to create a relationship from a process event to architecture information, or $F \& R$ information. This mechanism ensures that up-to-date RDD-100 information is available to all the events in the DPM.

\subsection{ORM}

The TWRS will generate products to communicate the Program's technical baseline evolution. Figure 3-3 provides a comprehensive view of the SE products and their relationships to one another. The following is brief description of the major SE technical products.

The initial mission analysis is described in a mission analysis report. The TWRS system-level requirements will be published in an F\&R document. Further definition of program-level requirements will be published in a TRS, DRD, and project development specifications. Architecture concepts will be published in BSDs and project design concepts. Design agreements among participants will be documented using interface control documents

(ICD). Tables 3-1 and 3-2 provide a more detailed listing and brief explanation of the major products.

\subsection{DPM DICTIONARY}

The DPM dictionary is presented in Table 3-3.

\subsection{ORM DICTIONARY}

The ORM dictionary is presented in Table 3-4. 


\section{WHC-SD-WM-PD-048 REV 0}

Figure 3-1. Systems Engineering Process Dynamic Process Model Context Level.

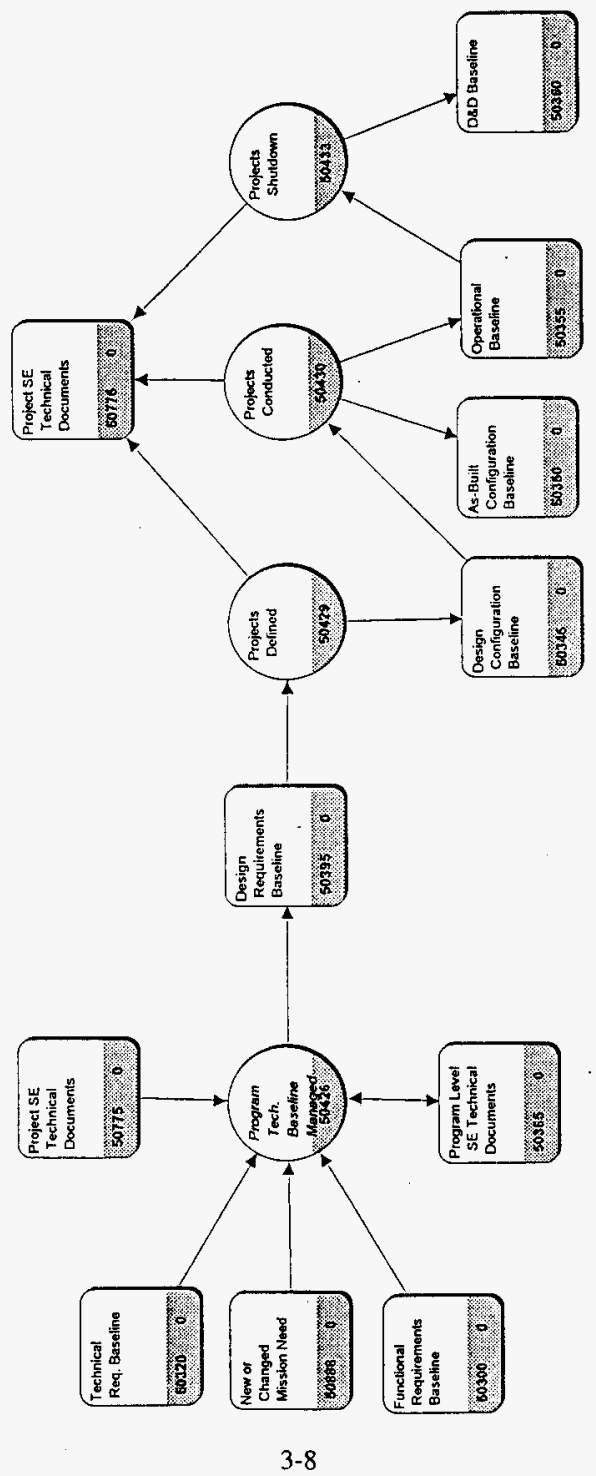


Figure 3-2. Systems Engineering Process Dynamic Process Model Detail Level. (5 sheets)

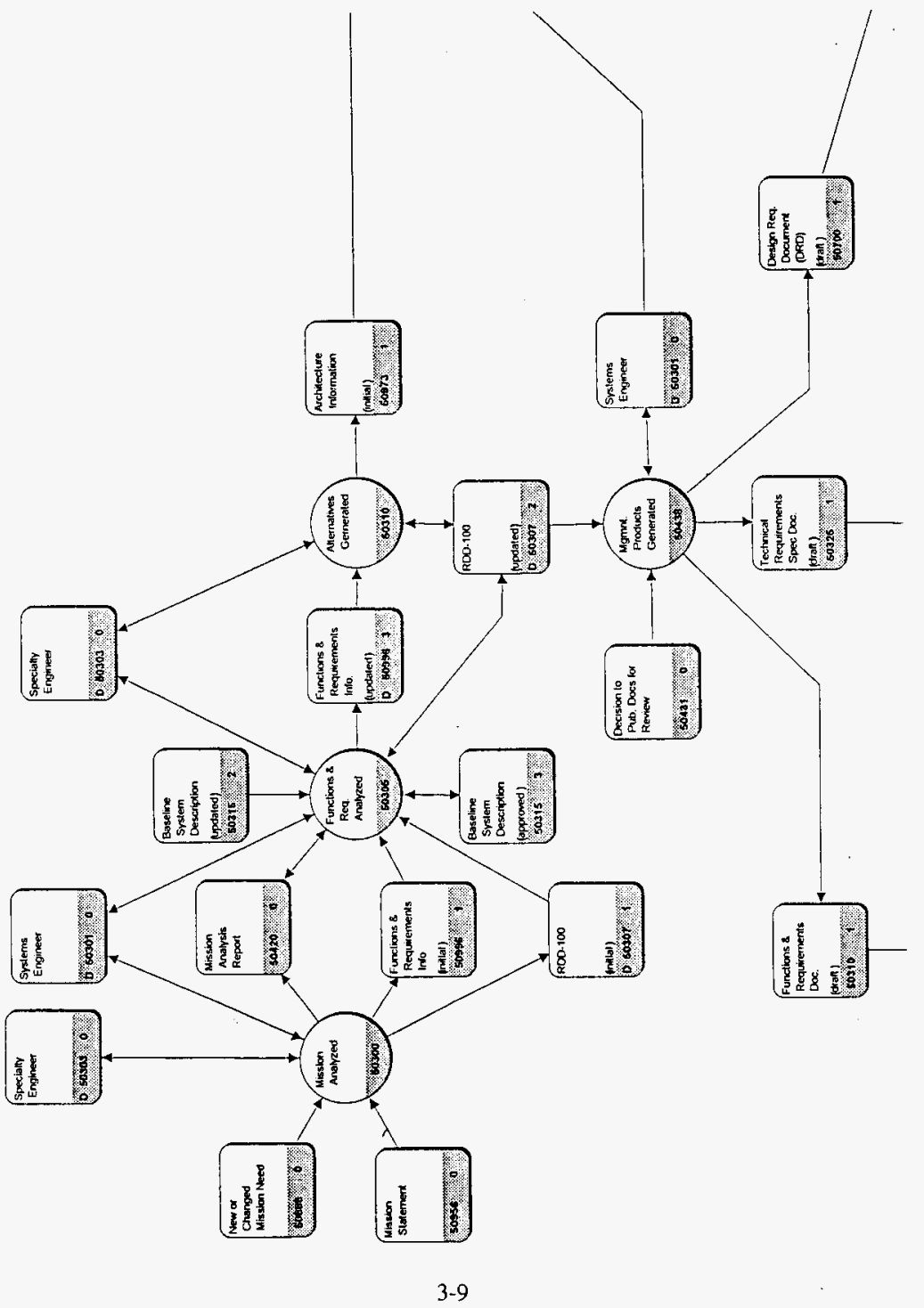


Figure 3-2. Systems Engineering Process Dynamic Process Model Detail Level. (5 sheets)

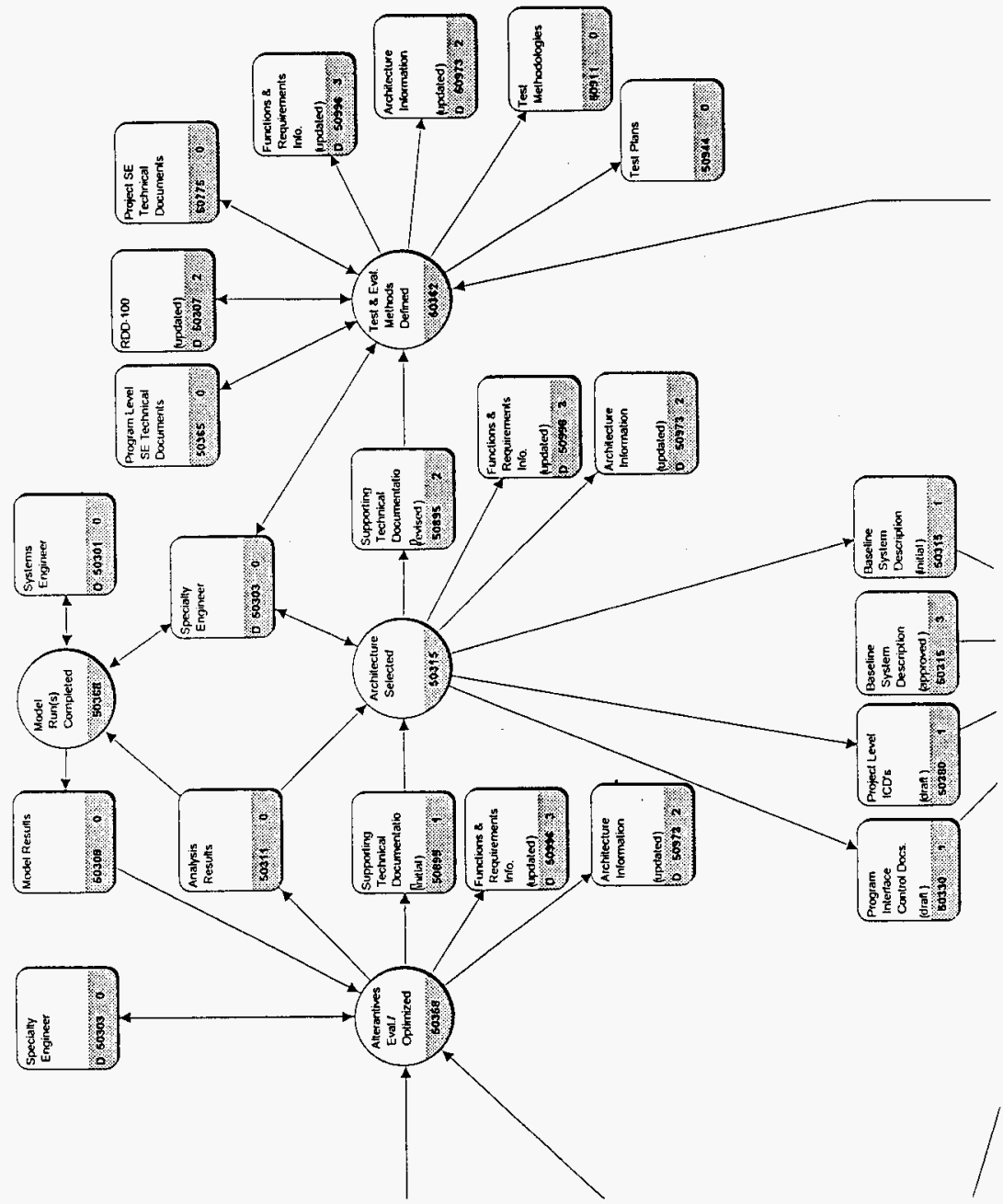


WHC-SD-WM-PD-048 REV 0

Figure 3-2. Systems Engineering Process Dynamic Process Model Detail Level. (5 sheets)

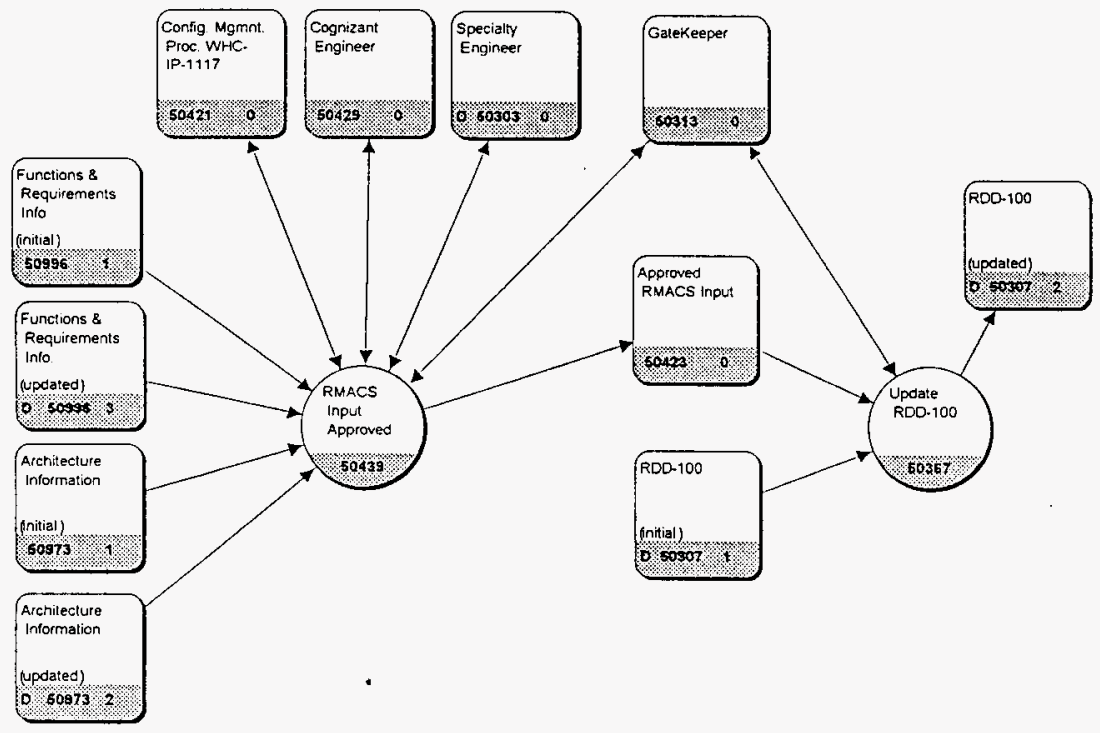


Figure 3-2. Systems Engineering Process Dynamic Process Model Detail Level. (5 sheets)

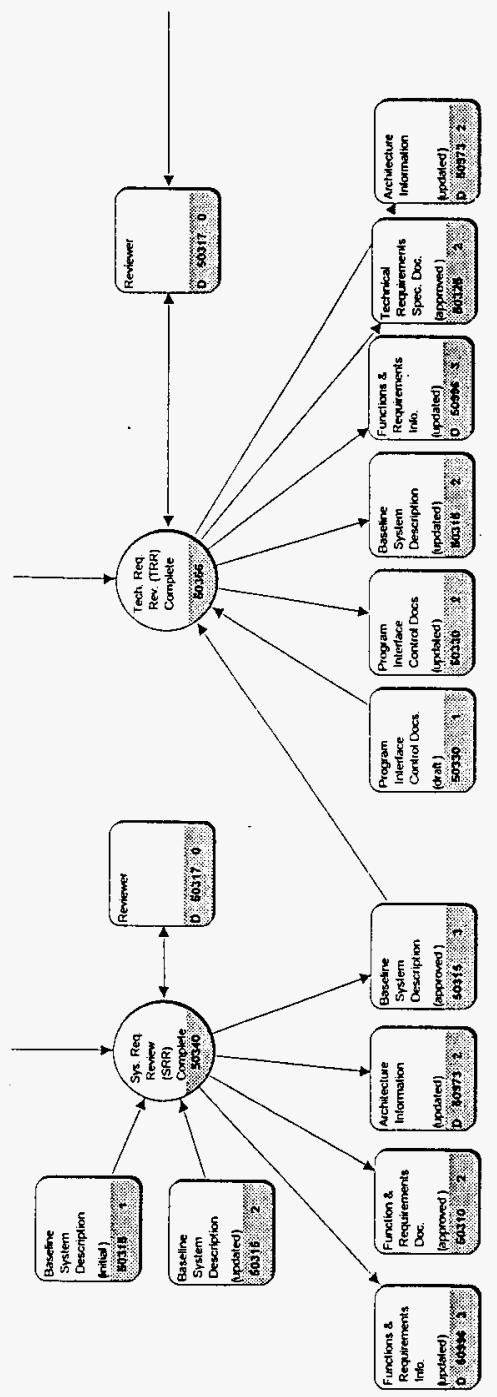




\section{WHC-SD-WM-PD-048 REV 0}

Figure 3-2. Systems Engineering Process Dynamic Process Model Detail Level. (5 sheets)

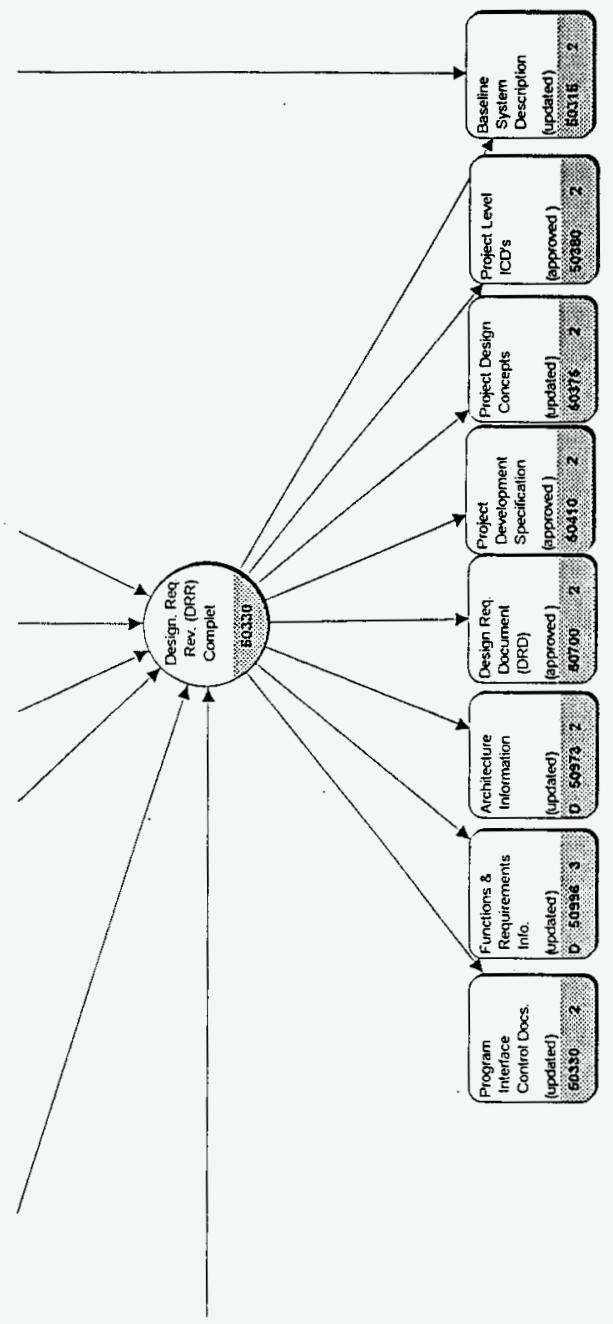


Figure 3-3. Systems Engineering Process Dynamic Process Model Object Relationship Model. (4 sheets)

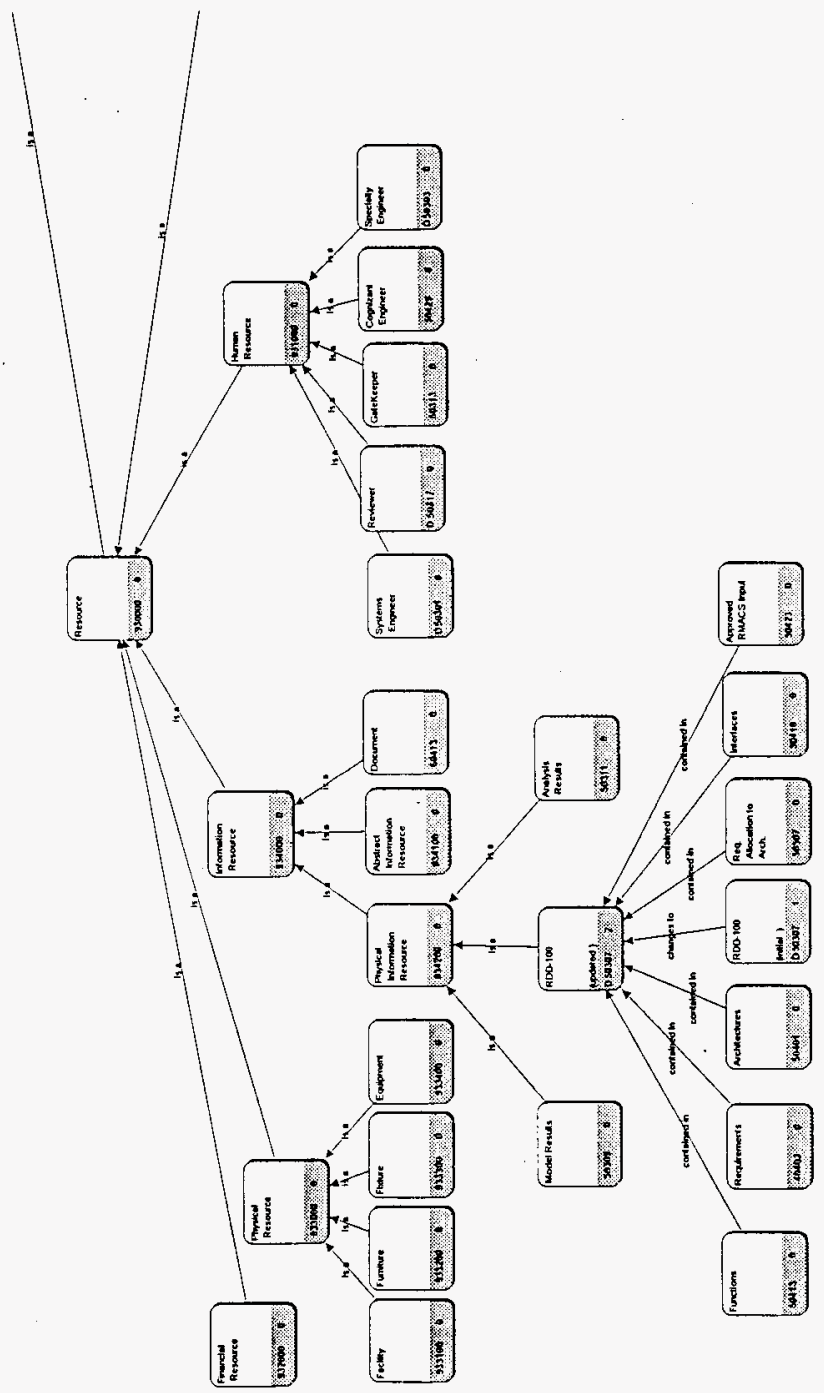


Figure 3-3. Systems Engineering Process Dynamic Process Model Object Relationship Model. (4 sheets)

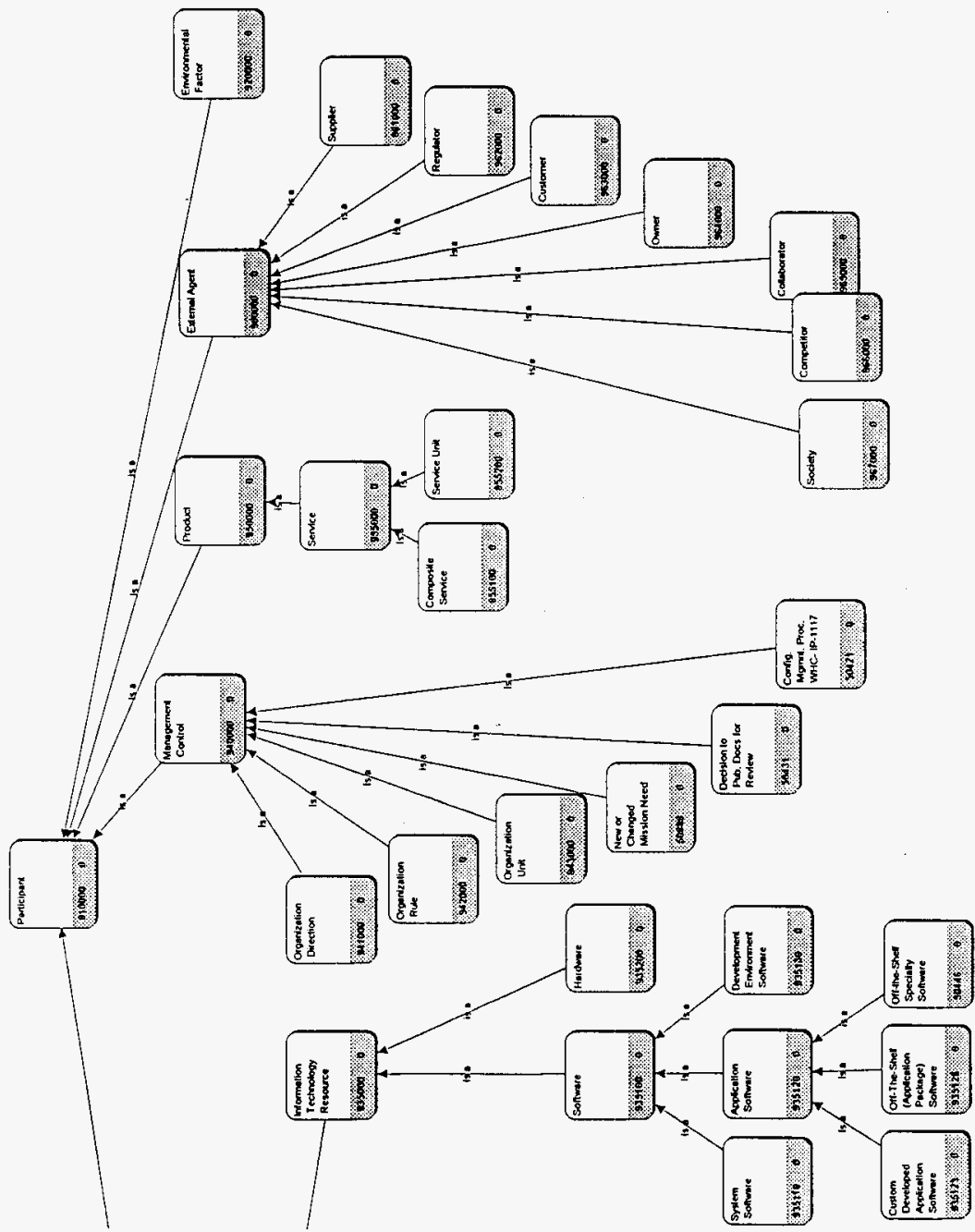


Figure 3-3. Systems Engineering Process Dynamic Process Model Object Relationship Model. (4 sheets)

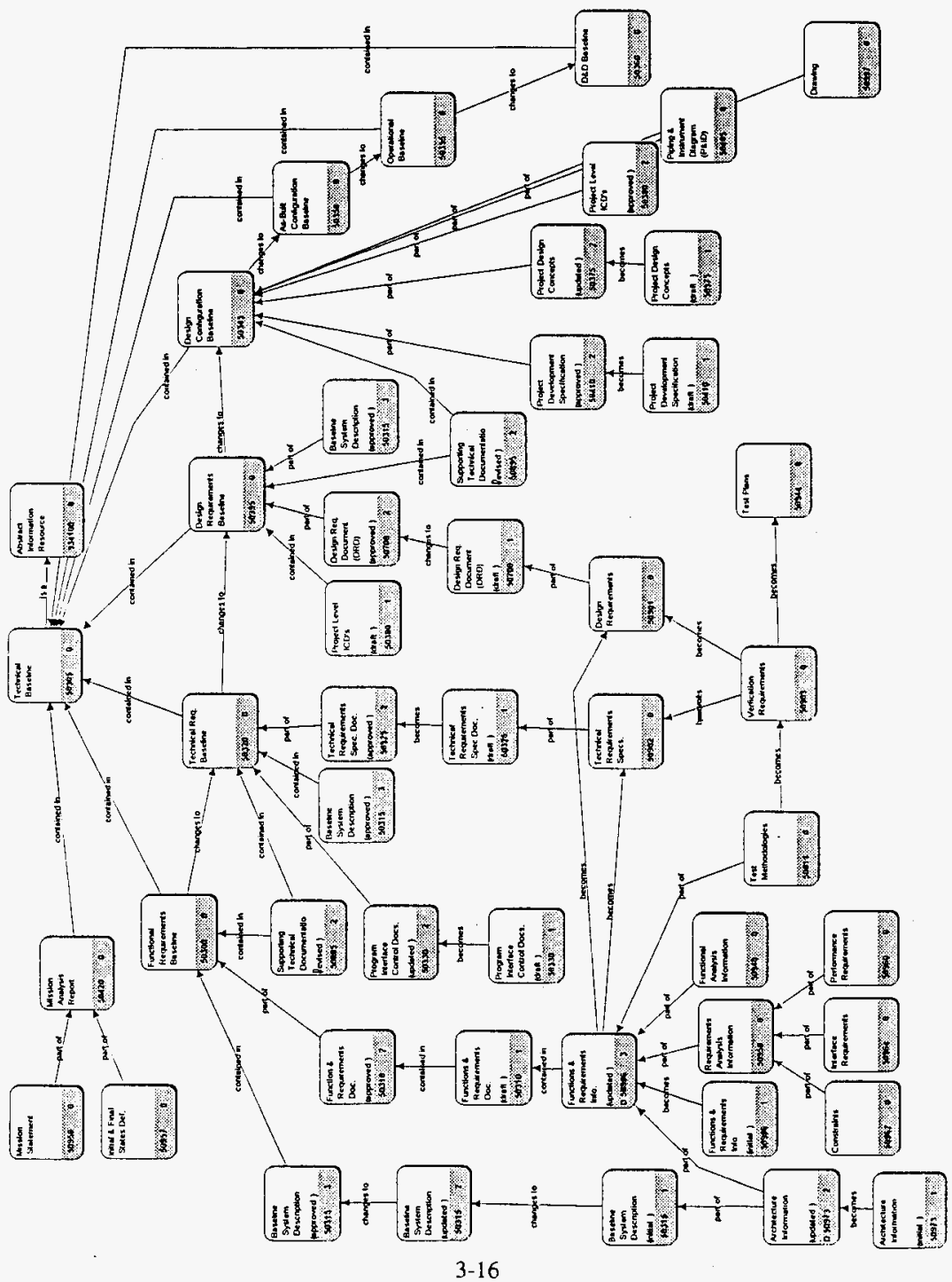


Figure 3-3. Systems Engineering Process Dynamic Process Model Object Relationship Model. (4 sheets)

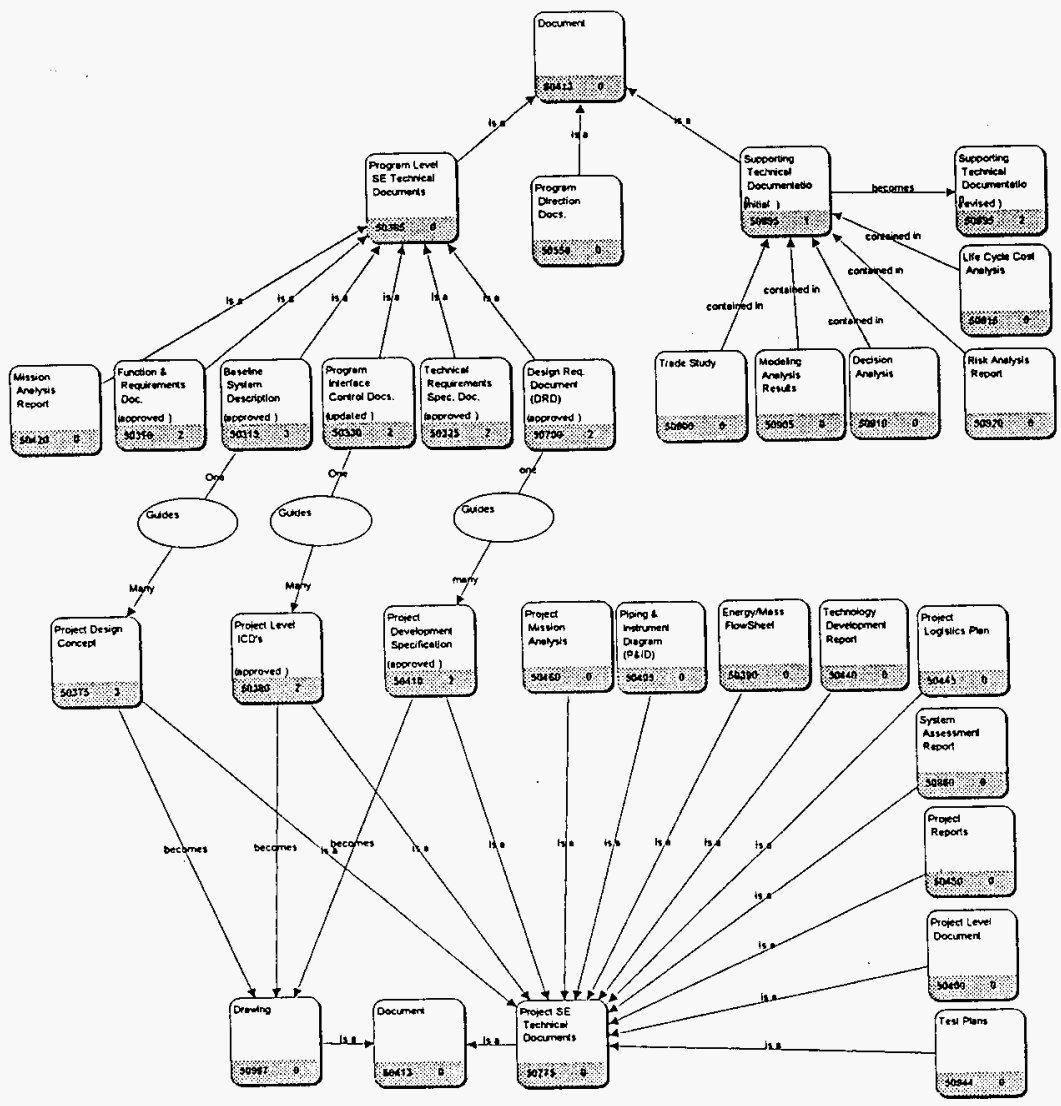




\section{WHC-SD-WM-PD-048 REV 0}

Table 3-1. Program-Level Systems Engineering Technical Documents.

\begin{tabular}{|c|c|}
\hline $\begin{array}{l}\text { Prograin } \\
\text { document }\end{array}$ & Document description \\
\hline $\begin{array}{l}\text { Mission analysis } \\
\text { report }\end{array}$ & $\begin{array}{l}\text { Docuinents the mission analysis results that translate mission needs and objectives } \\
\text { from the mission or problem statement and other top-level documents into mission } \\
\text { requirements. Includes top-level system architecture concepts, operations, and } \\
\text { maintenance strategies. }\end{array}$ \\
\hline $\begin{array}{l}\text { TWRS functions } \\
\text { and } \\
\text { requirements } \\
\text { document }\end{array}$ & $\begin{array}{l}\text { Documents the results of the functions and requirements analysis and allocation } \\
\text { process that transforms the mission analysis results into a set of executable functions } \\
\text { defined by requirements including constraints, functional, interface, and performance } \\
\text { requirements. Includes top-level functions analysis, requirements identification and } \\
\text { assignment, architecture selections, and test methodologies. }\end{array}$ \\
\hline $\begin{array}{l}\text { Baseline systems } \\
\text { description }\end{array}$ & $\begin{array}{l}\text { Contains summary text and illustrations for visualizing the selected architectures. } \\
\text { References to trade study reports are included as pointers to the detailed supporting } \\
\text { infornation as it develops. Used as a communication tool for cost estimates and } \\
\text { studies, and the next level of requirements generation. Updated for independent } \\
\text { teviews and tor each baseline revision to maintain baseline definition. }\end{array}$ \\
\hline $\begin{array}{l}\text { Intertace control } \\
\text { document }\end{array}$ & $\begin{array}{l}\text { Doeuments design agreements between projects and program or the program and the } \\
\text { external environment. }\end{array}$ \\
\hline $\begin{array}{l}\text { Technical } \\
\text { requirements } \\
\text { specification }\end{array}$ & $\begin{array}{l}\text { Documents the functions and requirements analysis and allocation results in a } \\
\text { specification format starting from the TWRS functions and requirements document and } \\
\text { continuing until the major program element missions are defined to a level that } \\
\text { functions and requirements are sufficiently detailed to assign to projects. Includes } \\
\text { tunctions and requirements analysis results: interface, performance, and verification } \\
\text { requirements. }\end{array}$ \\
\hline $\begin{array}{l}\text { Design } \\
\text { requirements } \\
\text { documents }\end{array}$ & $\begin{array}{l}\text { Reference intefface control documents, functions, and requirements allocated to a } \\
\text { specific project. Describes the essential technical requirements for designing, } \\
\text { constructing, operating, and maintaining the system. Includes the verification } \\
\text { requirements for determining if the requirements have been met. Will be used by the } \\
\text { project as a starting point for the design process. }\end{array}$ \\
\hline
\end{tabular}

TWRS $=$ Tank Waste Remediation System 
WHC-SD-WM-PD-048 REV 0

Table 3-2. Project Systems Engineering Technical Documents.

\begin{tabular}{|c|c|}
\hline $\begin{array}{l}\text { Project } \\
\text { document }\end{array}$ & Docurnent description \\
\hline $\begin{array}{l}\text { Project mission } \\
\text { analysis }\end{array}$ & $\begin{array}{l}\text { Produced only when the design requirements document is not available to the project. } \\
\text { Documents the mission analysis results for the project. Gives the project mission } \\
\text { objectives and establishes a link to the program mission. }\end{array}$ \\
\hline $\begin{array}{l}\text { Project interface } \\
\text { control } \\
\text { documents }\end{array}$ & Documents design agreements within a project and between projects. \\
\hline $\begin{array}{l}\text { Project design } \\
\text { concept }\end{array}$ & A project-level baseline system description. See Table 3-1 for more information. \\
\hline $\begin{array}{l}\text { Project } \\
\text { development } \\
\text { sjecification }\end{array}$ & $\begin{array}{l}\text { Lower-level specification based on the project functions and requirements analysis } \\
\text { and traceable to the program-level requirements in the design requirements document. } \\
\text { Provided as basis to perform design. }\end{array}$ \\
\hline $\begin{array}{l}\text { Mass/energy } \\
\text { tow sheets }\end{array}$ & $\begin{array}{l}\text { Mass and energy flow sheets describing clearly to the Architect-Engineer or design } \\
\text { group what the process must do. }\end{array}$ \\
\hline $\begin{array}{l}\text { Piping and } \\
\text { instrumentation } \\
\text { diagram }\end{array}$ & Diagram showing piping and instrumentation schematic layouts. \\
\hline $\begin{array}{l}\text { Tectinology } \\
\text { development } \\
\text { report }\end{array}$ & $\begin{array}{l}\text { Summarizes emerging or innovative technologies used in design concept. Addresses } \\
\text { technital adequacy of the technology. Summarizes associated risk management and } \\
\text { technology evaluation plan. (Supporting document, only written if using emerging or } \\
\text { innovative technologies.) }\end{array}$ \\
\hline $\begin{array}{l}\text { Project logistics } \\
\text { plan }\end{array}$ & $\begin{array}{l}\text { Describes the desired logistics program for supporting the project architecture. The } \\
\text { plan addresses system availability; maintenance planning; supply support; technical } \\
\text { data requirements; computer resources support; stafting; training support } \\
\text { requirements; and packaging, handling, storage, and transportation requirements. }\end{array}$ \\
\hline Project reports & $\begin{array}{l}\text { Reports needed by the project to fully detine their project activities. Examples of } \\
\text { project reports are alternative solution reports, trade study reports, or decision } \\
\text { analysis reports. These reports doument project-level work related to choosing the } \\
\text { project design solution. }\end{array}$ \\
\hline $\begin{array}{l}\text { System } \\
\text { atisesiment } \\
\text { reports }\end{array}$ & $\begin{array}{l}\text { Documents the approach and results of assessing existing systems against allocated } \\
\text { requirements to determine what modifications (if any) are required so the system } \\
\text { complies with requirements. }\end{array}$ \\
\hline
\end{tabular}


Table 3-3. Dynamic Process Model Dictionary. (3 sheets)

\begin{tabular}{|c|c|c|}
\hline Business event & Ref \# & Description \\
\hline $\begin{array}{l}\text { Alternatives } \\
\text { Eval./ } \\
\text { Optimized }\end{array}$ & 50358 & $\begin{array}{l}\text { Evaluation and optimization provide the main feedback mechanism for the SE process and facilitate } \\
\text { the development of a balanced, optimized design solution. Thus, evaluation and optimization are } \\
\text { performed throughout the SE process. Typically, there are numerous considerations in selecting an } \\
\text { optimum system and the evaluation and optimization process ensures that no single characteristic } \\
\text { dominates the design. }\end{array}$ \\
\hline $\begin{array}{l}\text { Alternatives } \\
\text { Generated }\end{array}$ & 50310 & $\begin{array}{l}\text { This event identifies and analyzes alternative system configurations that satisfy mission analysis and } \\
\text { technical baseline } F \& R \text { to make alternative architecture selection decisions. All reasonable } \\
\text { alternative architectural concepts are screened against the F\&R. Those that satisfy all requirements } \\
\text { are candidates for further analysis and decision making. When existing systems are an altemative, } \\
\text { the system is assessed against the requirements, all deficiencies are identified, and the resources } \\
\text { required to modify the system are estimated for use in evaluation and optimization activities. }\end{array}$ \\
\hline $\begin{array}{l}\text { Architecture } \\
\text { Selected }\end{array}$ & 50315 & A specific architecture is selected and will be further developed through one or more projects. \\
\hline $\begin{array}{l}\text { Design Req. } \\
\text { Rev. } \\
\text { Completed }\end{array}$ & 50338 & $\begin{array}{l}\text { A DRR is held for each project to demonstrate readiness for proceeding to design development. } \\
\text { DRRs are conducted to (1) verify project requirements conform with system requirements; } \\
\text { (2) identify requirements to be refined by the project; and (3) approve the project DRD, project } \\
\text { architecture, and the design requirements baseline. For each project, the responsible WHC Project } \\
\text { organization organizes and conducts the DRR. The RL TWRS Program Office participates in } \\
\text { selected reviews, and the M\&O is the reviewing authority. The products presented during the DRR } \\
\text { form the foundation for the Key Decision } 0 \text { review. }\end{array}$ \\
\hline $\begin{array}{l}\text { Functions \& } \\
\text { Req. Analyzed }\end{array}$ & 50305 & $\begin{array}{l}\text { This process transforms mission analysis results into F\&R for accomplishing the mission. Existing } \\
\text { architecture and initial conditions are used as inputs to this process. Functions and requirements } \\
\text { analyses and allocation breaks down complex systems into simpler related parts. The result is a } \\
\text { framework of functions, constrained by applicable requirements, to satisfy the mission. }\end{array}$ \\
\hline $\begin{array}{l}\text { Mission } \\
\text { Analyzed }\end{array}$ & 50300 & $\begin{array}{l}\text { This event consists of the high-level evaluation of the mission statement, generated to provide } \\
\text { sufficient information to allow the accomplisiment of functional decomposition, the derivation of } \\
\text { requirements, and the evaluation of architectures that will meet the mission objectives. }\end{array}$ \\
\hline $\begin{array}{l}\text { Model Runs } \\
\text { Completed }\end{array}$ & 50368 & $\begin{array}{l}\text { TWRS systems and specialty engineers use a number of numerical models to perform alternatives } \\
\text { analysis, evaluation, verification, and testing. These models are typically run many times, with } \\
\text { various input and environmental parameters. The results of these models are used to support various } \\
\text { phases of the SE process, and/or to refine the parameters for the next run of a specific model. }\end{array}$ \\
\hline
\end{tabular}


Table 3-3. Dynamic Process Model Dictionary. (3 sheets)

\begin{tabular}{|c|c|c|}
\hline Business event & $\operatorname{Ref} \#$ & Description \\
\hline $\begin{array}{l}\text { Program } \\
\text { Technical } \\
\text { Baseline } \\
\text { Managed }\end{array}$ & 50426 & $\begin{array}{l}\text { This event consists of SE the application of scientific and engineering principles to (1) transform an } \\
\text { operational need into a system of defined performance and configuration characteristics through } \\
\text { iterative, disciplined, and documented processes; (2) ensure all necessary related parameters are } \\
\text { integrated to optimize a system design that meets program cost, schedule, and technical performance } \\
\text { goals; and (3) maintain controlled definition of the system during its life cycle. SE the approach } \\
\text { selected by the DOE establishes and maintains the TWRS Program baseline during the life of the } \\
\text { program. }\end{array}$ \\
\hline $\begin{array}{l}\text { Projects } \\
\text { Conducted }\end{array}$ & 50430 & $\begin{array}{l}\text { The project is performed in accordance with the DRD and subsequent project-level documents. } \\
\text { Projects may be performed by TWRS personnel, subcontractors, and external agencies. }\end{array}$ \\
\hline $\begin{array}{l}\text { Projects } \\
\text { Defined }\end{array}$ & 50429 & $\begin{array}{l}\text { The start of a "project" is defined by a specification, called a DRD, generated by the program. } \\
\text { However, some TWRS projects have started before program generation of a DRD. In these cases, } \\
\text { where it has been decided to continue the project, a modification to the normal SE process must be } \\
\text { carried out. Typically this involves project generation of a project mission analysis, and an } \\
\text { "equivalent" DRD, along with an up-front determination of the program risks assumed by this } \\
\text { process. }\end{array}$ \\
\hline $\begin{array}{l}\text { Projects } \\
\text { Shutdown }\end{array}$ & 50433 & This event is the final phase of the project life cycle (i.e., termination). \\
\hline $\begin{array}{l}\text { RMACS Input } \\
\text { Approved }\end{array}$ & 50439 & This is the formal configuration control process for updating RDD-100. \\
\hline $\begin{array}{l}\text { Systems } \\
\text { Req. Rev } \\
\text { Completed }\end{array}$ & 50340 & $\begin{array}{l}\text { The SRR is a program-level review, conducted to evaluate progress in defining the program F\&R, } \\
\text { the architectural concept to satisfy mission needs, and to approve the functional requirements } \\
\text { baseline. The WHC TWRS Technical Integration organization organizes the review with RL TWRS } \\
\text { Office participation. DOE is the reviewing authority. }\end{array}$ \\
\hline
\end{tabular}


Table 3-3. Dynamic Process Model Dictionary. (3 sheets)

\begin{tabular}{|c|c|c|}
\hline Business event & Ref \# & Description \\
\hline $\begin{array}{l}\text { Technical Req. } \\
\text { Rev. } \\
\text { Completed }\end{array}$ & 50356 & $\begin{array}{l}\text { The TRR is a program-level review of system requirements. It is conducted to (1) evaluate the } \\
\text { system requirements for adequacy and risk; (2) ensure a mutual understanding among TWRS } \\
\text { Program and Project participants of TWRS Program system requirements, the corresponding system } \\
\text { architecture (design concepts), and test strategies; (3) assess the SE process that produced the system } \\
\text { requirements; and (4) approve the technical requirements baseline. } \\
\text { The WHC TWRS Technical Integration organizes and conducts the TRR, with RL participation, } \\
\text { DOE is the reviewing authority. The TRRs will be phased, reviewing the portion of the baseline } \\
\text { applicable to specific architecture elements with sufficient commonality to combine into one review. }\end{array}$ \\
\hline $\begin{array}{l}\text { Test \& Eval. } \\
\text { Methods } \\
\text { Defined }\end{array}$ & 50362 & $\begin{array}{l}\text { The test plans and strategies are defined for the specific architecture. The results of this process will } \\
\text { be used to define lower-level test plans at the project and sub-project levels. }\end{array}$ \\
\hline $\begin{array}{l}\text { Update } \\
\text { RDD-100 }\end{array}$ & 50367 & $\begin{array}{l}\text { Revised or new F\&R and/or architectures are input into the RDD-100 database. "Gatekeepers" are } \\
\text { the only personnel authorized to update RDD-100 but it may be viewed by all users needing access. }\end{array}$ \\
\hline $\begin{array}{l}\text { DOE } \\
\text { DRD } \\
\text { DRR } \\
\text { F\&R } \\
\text { M\&O } \\
\text { RL } \\
\text { RMACS } \\
\text { SE } \\
\text { SRR } \\
\text { TRR } \\
\text { TWRS } \\
\text { WHC }\end{array}$ & $\begin{array}{l}=\text { U.S. } \\
=\text { Desig } \\
=\text { Desig } \\
=\text { Funct } \\
=\text { Mana } \\
=\text { U.S. } \\
=\text { Requi } \\
=\text { Syster } \\
=\text { Syster } \\
=\text { Techn } \\
=\text { Tank } \\
=\text { Westi }\end{array}$ & $\begin{array}{l}\text { epartment of Energy } \\
\text { requirements document } \\
\text { requirements review } \\
\text { ons and requirements } \\
\text { ement \& Operations } \\
\text { epartment of Energy, Richland Operations Office } \\
\text { ements Management and Assured Compliance System } \\
\text { is Engineering } \\
\text { requirements review } \\
\text { cal requirements review } \\
\text { Naste Remediation System } \\
\text { ghouse Hanford Company }\end{array}$ \\
\hline
\end{tabular}


Table 3-4. Object Relationship Model Dictionary. (8 sheets)

\begin{tabular}{|c|c|c|}
\hline Participant name & Ref. \# & Participant description \\
\hline Analysis Results & 50311 & $\begin{array}{l}\text { The conclusions, requirements, and/or issues resulting from the analysis of output from various } \\
\text { numerical models used by the SE process. }\end{array}$ \\
\hline $\begin{array}{l}\text { Approved } \\
\text { RMACS Input }\end{array}$ & 50423 & Approved input to the RDD-100 database. \\
\hline $\begin{array}{l}\text { Architecture } \\
\text { Information } \\
\text { (initial) }\end{array}$ & 50973 & $\begin{array}{l}\text { The initial information pertaining to a potential design solution that is used for further analysis and } \\
\text { design activities. }\end{array}$ \\
\hline $\begin{array}{l}\text { Architecture } \\
\text { Information } \\
\text { (updated) }\end{array}$ & 50973 & $\begin{array}{l}\text { Detailed, revised, or new information about a potential design solution that potentially satisfies the } \\
\text { requirements and is used for more detailed design activities. }\end{array}$ \\
\hline $\begin{array}{l}\text { As-Built } \\
\text { Configuration } \\
\text { Baseline }\end{array}$ & 50345 & $\begin{array}{l}\text { Constitutes the design of the as-built operational system. Confirmation of the as-built condition } \\
\text { ensures that the system is constructed according to the approved drawings and that the system } \\
\text { performance, quality of materials, and workmanship meet system requirements. }\end{array}$ \\
\hline $\begin{array}{l}\text { Baseline System } \\
\text { Description }\end{array}$ & 50315 & An initial, updated, or approved BSD document. \\
\hline $\begin{array}{l}\text { Baseline System } \\
\text { Description } \\
\text { (approved) }\end{array}$ & 50315 & A BSD document that has been approved through a formal review and approval process. \\
\hline $\begin{array}{l}\text { Baseline System } \\
\text { Description } \\
\text { (initial) }\end{array}$ & 50315 & Draft or in-work BSD document. \\
\hline $\begin{array}{l}\text { Baseline System } \\
\text { Description } \\
\text { (updated) }\end{array}$ & 50315 & $\begin{array}{l}\text { Final document that provides an overall description of the system, in an easily understood } \\
\text { illustration and narrative format for visualizing architecture concepts. It is used by the participants } \\
\text { working on the TWRS Program as a communication tool, and as a point of departure for briefings, } \\
\text { studies, and cost estimates. }\end{array}$ \\
\hline BSD Changes & 50036 & Changes to the draft BSD that, when incorporated, result in the updated version of the BSD. \\
\hline $\begin{array}{l}\text { Cognizant } \\
\text { Engineer }\end{array}$ & 50429 & An engineer who has decision-making responsibility for one or more technical aspects of a project. \\
\hline
\end{tabular}


Table 3-4. Object Relationship Model Dictionary. (8 sheets)

\begin{tabular}{|c|c|c|}
\hline Participant name & Ref. \# & Participant description \\
\hline Constraints & 50962 & $\begin{array}{l}\text { An externaliy imposed mandatory restriction, limitation, or requirement imposed by agencies and } \\
\text { organizations such as Congress, U.S. Environmental Protection Agency, Washington State } \\
\text { Department of Ecology, and other regulatory agencies, and DOE Orders, Secretarial Notices, and } \\
\text { other regulatory documents. Where necessary, these constraints will be interpreted to derive } \\
\text { performance requirements that are quantified and verifiable. }\end{array}$ \\
\hline D\&D Baseline & 50360 & $\begin{array}{l}\text { The documented F\&R and configuration from which the program will define the decontamination } \\
\text { and decommissioning portion of the technical baseline. Describes all or part of the activity's } \\
\text { functionaI, performance, inter-operability, interface, and verification requirements necessary to } \\
\text { demonstrate the achievement of those specified requirements. }\end{array}$ \\
\hline Decision Analysis & 50910 & $\begin{array}{l}\text { A document that describes the factors used to select a preferred alternative. A decision criterion } \\
\text { may be quantitative or qualitative. }\end{array}$ \\
\hline $\begin{array}{l}\text { Decision to Pub. } \\
\text { Docs. for Review }\end{array}$ & 50431 & $\begin{array}{l}\text { A decision by management and supporting engineering staff to proceed with a formal review of a } \\
\text { major SE document deliverable. }\end{array}$ \\
\hline $\begin{array}{l}\text { Design } \\
\text { Requirements } \\
\text { Baseline }\end{array}$ & & $\begin{array}{l}\text { The documented F\&R and configuration from which the program will define the design } \\
\text { requirements portion of the technical baseline. It consists of the "build to," "code to," and "buy } \\
\text { to" requirements for products and "how to execute" requirements for processes. }\end{array}$ \\
\hline $\begin{array}{l}\text { Design Req. } \\
\text { Document (draft) }\end{array}$ & 50700 & Draft or in-work DRDs. \\
\hline $\begin{array}{l}\text { Design Req. } \\
\text { Document } \\
\text { (approved) }\end{array}$ & 50700 & $\begin{array}{l}\text { Documents that are approved through the design requirements review and are provided to projects } \\
\text { from program elements. DRDs include reference ICDs and F\&R allocated to a specific project. } \\
\text { Describes the essential technical requirements for designing, constructing, operating, and } \\
\text { maintaining the system. Includes the verification requirements for determining if the requirements } \\
\text { have been met. Will be used by the project as a starting point for the design process. DRDs } \\
\text { establish the baseline which the program elements maintain. }\end{array}$ \\
\hline $\begin{array}{l}\text { Design } \\
\text { Requirements }\end{array}$ & 50501 & $\begin{array}{l}\text { The "build to," "code to," and "buy to" requirements for products and "how to execute" } \\
\text { requirements for processes. Design requirements are developed through synthesis of detailed } \\
\text { performance requirements, engineering standards, and design concepts. }\end{array}$ \\
\hline
\end{tabular}


Table 3-4. Object Relationship Model Dictionary. (8 sheets)

\begin{tabular}{|c|c|c|}
\hline Participant name & Ref. \# & Participant description \\
\hline Drawings & 50997 & $\begin{array}{l}\text { Any combination of drawings that depicts engineering, erection, installation, assembly, or } \\
\text { fabrication work involved in creating a new facility or altering, adding to, or rehabilitating an } \\
\text { existing facility. It also includes the alteration and repair (including dredging, excavating, and } \\
\text { painting) of buildings, structures, or other real property. }\end{array}$ \\
\hline $\begin{array}{l}\text { Energy/Mass } \\
\text { Flowsheet }\end{array}$ & 50390 & $\begin{array}{l}\text { Mass and energy flowsheets describing clearly to the Architect-Engineer or design group what the } \\
\text { process must do. }\end{array}$ \\
\hline $\begin{array}{l}\text { Functional } \\
\text { Analysis } \\
\text { Information }\end{array}$ & 50940 & $\begin{array}{l}\text { Information describing specific characteristics based on analyses of customer needs, requirements, } \\
\text { and objectives; missions; projected environments for personnel, products, and processes; } \\
\text { constraints; and measures of effectiveness. }\end{array}$ \\
\hline $\begin{array}{l}\text { Functional } \\
\text { Requirements } \\
\text { Baseline }\end{array}$ & 50300 & $\begin{array}{l}\text { Constitutes the basis of the F\&R and architectures for TWRS. This the first major evolution of the } \\
\text { technical baseline and consists of the F\&R document and initial BSD document. Confirmation of } \\
\text { functional requirements baseline enables work to begin on the technical requirements baseline. }\end{array}$ \\
\hline $\begin{array}{l}\text { Functions \& } \\
\text { Requirements } \\
\text { Doc. (approved) }\end{array}$ & 50310 & An F\&R document approved through the systems requirement review process. \\
\hline $\begin{array}{l}\text { Functions \& } \\
\text { Requirements } \\
\text { Doc. (draft) }\end{array}$ & 50310 & $\begin{array}{l}\text { A draft or in-work document containing the high-level definition of F\&R and candidate } \\
\text { architectural concepts that are in line with the stated mission objectives and defined mission } \\
\text { constraints. }\end{array}$ \\
\hline $\begin{array}{l}\text { Functions \& } \\
\text { Requirements } \\
\text { Info. (initial) }\end{array}$ & 50966 & $\begin{array}{l}\text { Information related to the high-level definition of } F \& R \text { and candidate architectural concepts that are } \\
\text { in line with the stated mission objectives and defined mission constraints. }\end{array}$ \\
\hline $\begin{array}{l}\text { Functions \& } \\
\text { Requirements } \\
\text { Info. (updated) }\end{array}$ & 50966 & $\begin{array}{l}\text { New, revised, or more detailed F\&R information resulting from further analysis, alternative } \\
\text { architecture generation, optimization, and test method determination. }\end{array}$ \\
\hline Gatekeeper & 50313 & Person authorized to update the RDD-100 database. \\
\hline $\begin{array}{l}\text { Initial \& Final } \\
\text { States Definition }\end{array}$ & 50957 & A high-level analysis of the current conditions of the TWRS and the desired final conditions. \\
\hline
\end{tabular}


Table 3-4. Object Relationship Model Dictionary. (8 sheets)

\begin{tabular}{|c|c|c|}
\hline Participant name & Ref. \# & Participant description \\
\hline $\begin{array}{l}\text { Interface } \\
\text { Requirements }\end{array}$ & 50964 & $\begin{array}{l}\text { A design agreement or condition between interfacing hardware, or software systems, which fully } \\
\text { defines the interface. Interface requirements must be met to enable the different sub-systems to } \\
\text { function as a whole. }\end{array}$ \\
\hline $\begin{array}{l}\text { Life-Cycle Cost } \\
\text { Analysis }\end{array}$ & 50915 & $\begin{array}{l}\text { Determination of the sum total of direct, indirect, recurring, non-recurring, and other related costs } \\
\text { incurred or estimated to be incurred in the acquisition, operation, decommissioning, and disposal of } \\
\text { a designated item. }\end{array}$ \\
\hline $\begin{array}{l}\text { Mission Analysis } \\
\text { Report }\end{array}$ & 50420 & $\begin{array}{l}\text { A document describing the mission analysis results. It translates mission needs and objectives from } \\
\text { the mission or problem statement and other top-level documents into mission requirements. } \\
\text { Includes top-level system architecture concepts, operations, and maintenance strategies. }\end{array}$ \\
\hline $\begin{array}{l}\text { Mission } \\
\text { Statement }\end{array}$ & 50956 & A short declaration of what is to be accomplished. \\
\hline Model Results & 50308 & $\begin{array}{l}\text { Numerical or other determinations made from the evaluation and optimization of outputs from } \\
\text { computerized models. }\end{array}$ \\
\hline $\begin{array}{l}\text { Operational } \\
\text { Baseline }\end{array}$ & 50355 & $\begin{array}{l}\text { The documented F\&R and configuration that describe the operating system. Describes all or part } \\
\text { of the systems functional, performance, inter-operability, interface, and verification. }\end{array}$ \\
\hline $\begin{array}{l}\text { Performance } \\
\text { Requirements }\end{array}$ & 50960 & $\begin{array}{l}\text { The extent to which a mission or function must be executed, generally measured in terms of } \\
\text { quantity, quality, coverage, timeliness, or readiness. Performance requirements are initially } \\
\text { defined through requirements analyses and trade studies using mission need, objective, and/or } \\
\text { requirement statements. Performance requirements are assigned to lower-level system functions } \\
\text { through top-down allocation, and are assigned to programs, program elements and projects through } \\
\text { synthesis. }\end{array}$ \\
\hline $\begin{array}{l}\text { Piping \& } \\
\text { Instrument } \\
\text { Diagram }\end{array}$ & 50405 & Diagram showing piping and instrumentation schematic layouts. \\
\hline $\begin{array}{l}\text { Program } \\
\text { Direction Docs. }\end{array}$ & 50556 & $\begin{array}{l}\text { Documents from DOE and/or other external agencies that provide high-level guidance to the } \\
\text { TWRS Program. }\end{array}$ \\
\hline $\begin{array}{l}\text { Program Interface } \\
\text { Control Docs. } \\
\text { (draft) }\end{array}$ & 50330 & Draft or in-work program ICD. \\
\hline
\end{tabular}


Table 3-4. Object Relationship Model Dictionary. (8 sheets)

\begin{tabular}{|c|c|c|}
\hline Participant name & Ref. \# & Participant description \\
\hline $\begin{array}{l}\text { Program Interface } \\
\text { Control Docs. } \\
\text { (updated) }\end{array}$ & 50330 & $\begin{array}{l}\text { Approved document (through the technical requirements review), representing a design agreement } \\
\text { between projects and programs or the programs' external environment. }\end{array}$ \\
\hline $\begin{array}{l}\text { Program-Level } \\
\text { SE Technical } \\
\text { Documents }\end{array}$ & 50365 & SE documents that communicate the program's technical baseline evolution. \\
\hline $\begin{array}{l}\text { Project Design } \\
\text { Concepts (draft) }\end{array}$ & 50375 & A project-level BSD. \\
\hline $\begin{array}{l}\text { Project Design } \\
\text { Concepts } \\
\text { (updated) }\end{array}$ & 50375 & A BSD approved through the design requirements review process. \\
\hline $\begin{array}{l}\text { Project } \\
\text { Development } \\
\text { Specification } \\
\text { (approved) }\end{array}$ & 50410 & Project development specification approved through the design requirements review process. \\
\hline $\begin{array}{l}\text { Project } \\
\text { Development } \\
\text { Specification } \\
\text { (draft) }\end{array}$ & 50410 & $\begin{array}{l}\text { Draft or in-work lower-level specification based on the project F\&R analysis and traceable to the } \\
\text { program-level requirements in the DRD. Provided as basis to perform design. }\end{array}$ \\
\hline $\begin{array}{l}\text { Project Logistics } \\
\text { Plan }\end{array}$ & 50445 & $\begin{array}{l}\text { Describes the desired logistics program for supporting the project architecture. The plan addresses } \\
\text { system availability; maintenance planning; supply support; technical data requirements; computer } \\
\text { resources support; staffing; training support requirements; and packaging, handling, storage, and } \\
\text { transportation requirements. }\end{array}$ \\
\hline $\begin{array}{l}\text { Project Mission } \\
\text { Analysis }\end{array}$ & 50460 & $\begin{array}{l}\text { Produced only when the DRD is not available to the project. Documents the mission analysis } \\
\text { results for the project. Gives the project mission objectives and establishes a link to the program } \\
\text { mission. }\end{array}$ \\
\hline Project Reports & 50450 & $\begin{array}{l}\text { Reports needed by the project to fully define their project activities. Examples of project reports } \\
\text { are alternative solution reports, trade study reports, and decision analysis reports. These reports } \\
\text { document project-level work related to choosing the project design solution. }\end{array}$ \\
\hline
\end{tabular}


Table 3-4. Object Relationship Model Dictionary. (8 sheets)

\begin{tabular}{|c|c|c|}
\hline Participant name & Ref. \# & Participant description \\
\hline $\begin{array}{l}\text { Project SE } \\
\text { Technical } \\
\text { Documents }\end{array}$ & 50775 & SE documents that communicate the project's technical baseline evolution. \\
\hline $\begin{array}{l}\text { Project-Level } \\
\text { Document }\end{array}$ & 50400 & An aggregate of project documents. \\
\hline $\begin{array}{l}\text { Project-Level } \\
\text { ICD's (approved) }\end{array}$ & 50380 & Documents design agreements within a project and between projects. \\
\hline RDD-100 & 50307 & $\begin{array}{l}\text { The database that contains the F\&R and architectures that define the functional requirements } \\
\text { baseline. RDD-100 is the primary component of the RMACS. }\end{array}$ \\
\hline $\begin{array}{l}\text { Requirements } \\
\text { Analysis Info. }\end{array}$ & 50950 & $\begin{array}{l}\text { Information related to the determination of system-specific characteristics based on analyses of } \\
\text { customer needs, requirements, and objectives; missions; projected utilization environments for } \\
\text { people, products, and processes; constraints; and measures of effectiveness (i.e., how well the } \\
\text { system needs to perform a function). }\end{array}$ \\
\hline Reviewer & 50317 & Person(s) responsible for formal review of the technical baseline deliverables. \\
\hline $\begin{array}{l}\text { Risk Analysis } \\
\text { Report }\end{array}$ & 50920 & $\begin{array}{l}\text { A report on the probability of events occurring and the consequences of the potential events would } \\
\text { have on the program, should they occur. The purpose of risk analysis is to discover the causes, } \\
\text { effects, and magnitude of perceived risks. }\end{array}$ \\
\hline $\begin{array}{l}\text { Specialty } \\
\text { Engineer }\end{array}$ & 50303 & An engineer with specific skills and/or subject knowledge. \\
\hline $\begin{array}{l}\text { Supporting } \\
\text { Technical } \\
\text { Documentation } \\
\text { (initial) }\end{array}$ & 50895 & $\begin{array}{l}\text { Draft or in-work project-level documents used to support decisions and assumptions used in the } \\
\text { formation of the technical baseline. }\end{array}$ \\
\hline $\begin{array}{l}\text { Supporting } \\
\text { Technical } \\
\text { Documentation } \\
\text { (revised) }\end{array}$ & 50895 & $\begin{array}{l}\text { Approved, issued, or finalized project-level documents used to support decisions and assumptions } \\
\text { used in the formation of the technical baseline. }\end{array}$ \\
\hline
\end{tabular}


Table 3-4. Object Relationship Model Dictionary. (8 sheets)

\begin{tabular}{|c|c|c|}
\hline Participant name & Ref. $\#$ & Participant description \\
\hline $\begin{array}{l}\text { System } \\
\text { Assessment } \\
\text { Report }\end{array}$ & 50860 & $\begin{array}{l}\text { Documents the approach and results of assessing existing systems against allocated requirements to } \\
\text { determine what modifications (if any) are required so the system complies with requirements. }\end{array}$ \\
\hline Systems Engineer & 50301 & $\begin{array}{l}\text { An engineer designated to support or perform one or more of the sub-processes within the SE } \\
\text { process. }\end{array}$ \\
\hline $\begin{array}{l}\text { Technical } \\
\text { Baseline }\end{array}$ & 50305 & $\begin{array}{l}\text { The reference set of technical data. It contains all technical requirements, architectures, and } \\
\text { interfaces generated using the SE process to satisfy the TWRS mission need. To reflect the } \\
\text { evolution of the system description, the technical baseline is given different names as it matures. } \\
\text { The baselines are (1) functional requirements, (2) technical requirements, (3) design requirements, } \\
\text { (4) design configuration Phases } 1 \text { through } 3 \text {, (5) as-built configuration, (6) operational, and } \\
\text { (7) D\&D. }\end{array}$ \\
\hline $\begin{array}{l}\text { Technical } \\
\text { Requirements } \\
\text { Baseline }\end{array}$ & 50320 & $\begin{array}{l}\text { Constitutes the basis of the F\&R and architectures for TWRS in a specification format. This the } \\
\text { second major evolution of the technical baseline and consists of the TRS document and updated } \\
\text { BSDs and ICDs. Confirmation of the technical requirements baseline enables work to begin on the } \\
\text { design requirements baseline. }\end{array}$ \\
\hline $\begin{array}{l}\text { Technical } \\
\text { Requirements } \\
\text { Spec. Doc } \\
\text { (approved) }\end{array}$ & 50325 & $\begin{array}{l}\text { A TRS document that has been updated with comments and approved through the technical } \\
\text { requirements review. }\end{array}$ \\
\hline $\begin{array}{l}\text { Technical } \\
\text { Requirements } \\
\text { Spec. Doc (draft) }\end{array}$ & 50325 & $\begin{array}{l}\text { Draft or in-work document containing the F\&R analysis and allocation results in a specification } \\
\text { format starting from the TWRS FRD and continuing until the major program element missions are } \\
\text { defined to a level that } F \& R \text { are sufficiently detailed to assign to projects. Includes F\&R analysis } \\
\text { results: interface, performance, and verification requirements. }\end{array}$ \\
\hline $\begin{array}{l}\text { Technical } \\
\text { Requirements } \\
\text { Specifications }\end{array}$ & 50902 & $\begin{array}{l}\text { Defines the performance characteristics of a system necessary for the system to achieve its } \\
\text { objectives. }\end{array}$ \\
\hline $\begin{array}{l}\text { Technology } \\
\text { Development } \\
\text { Report }\end{array}$ & 50440 & $\begin{array}{l}\text { Summarizes emerging or innovative technologies used in design concept. Addresses technical } \\
\text { adequacy of the technology. Summarizes associated risk management and technology evaluation } \\
\text { plan. (Supporting document: only written if using emerging or innovative technologies.) }\end{array}$ \\
\hline
\end{tabular}


Table 3-4. Object Relationship Model Dictionary. (8 sheets)

\begin{tabular}{|c|c|c|}
\hline Participant name & Ref. $\#$ & Participant description \\
\hline $\begin{array}{l}\text { Test } \\
\text { Methodologies }\end{array}$ & 50911 & $\begin{array}{l}\text { The complete set of activities that verifies that end products meet customer requirements. Includes } \\
\text { reviews and analysis performed during the design process; inspection activities during } \\
\text { manufacturing and construction; and testing performed during design, manufacturing, construction, } \\
\text { and turnover activities. }\end{array}$ \\
\hline Test Plans & 50944 & $\begin{array}{l}\text { Documents that describe the test methodologies for specific program, project, or sub-project } \\
\text { activities. }\end{array}$ \\
\hline Trade Study & 50900 & $\begin{array}{l}\text { A process of comparing or trading the strengths and weaknesses of alternative approaches or } \\
\text { attributes } \\
\text { - A feedback process for resolving inconsistencies between the levels of an activity } \\
\text { - The analysis of the ability of a design solution to meet its stated objectives. }\end{array}$ \\
\hline $\begin{array}{l}\text { Verification } \\
\text { Requirements }\end{array}$ & 50903 & $\begin{array}{l}\text { Criteria to determine if items, activities, processes, services, or documents conform to specified } \\
\text { constraints, requirements or commitments. The method used to show compliance (test, inspection, } \\
\text { demonstration, or analysis) dependent on architecture complexity, engineering test data availability, } \\
\text { and validated analytical methods availability or existence. }\end{array}$ \\
\hline BSD & \multicolumn{2}{|c|}{$=$ Baseline system description } \\
\hline $\mathrm{D} \& \mathrm{D}$ & \multicolumn{2}{|c|}{$=$ Decontamination and decommissioning } \\
\hline DOE & \multicolumn{2}{|c|}{$=$ U.S. Department of Energy } \\
\hline DRD & \multicolumn{2}{|c|}{$=$ Design requirements document } \\
\hline F\&R & \multicolumn{2}{|c|}{$=$ Functions and requirements } \\
\hline ICD & \multicolumn{2}{|c|}{$=$ Interface control document } \\
\hline RMACS & \multicolumn{2}{|c|}{$=$ Requirements Management and Assured Compliance System } \\
\hline $\mathrm{SE}$ & \multicolumn{2}{|c|}{$=$ Systems Engineering } \\
\hline TRS & \multirow{2}{*}{\multicolumn{2}{|c|}{$=$ Technical requirements specification }} \\
\hline TWRS & & \\
\hline
\end{tabular}


WHC-SD-WM-PD-048 REV 0

\subsection{O\&M WORK MANAGEMENT PROCESS}

\subsection{EXECUTIVE SUMMARY}

This section presents the results of an analysis performed to document the current or As-Is processes of the O\&M work management process. The goal was to document the existing subprocesses, and to identify specific opportunities for improving the work management process and shortening the time required for completion of the work package document life cycle.

\subsubsection{Overview}

Operations and Maintenance consists of three major disciplines: work management, operations, and projects. The work management-related processes only will be discussed in this section as a result of the shortage of funding and time required to complete all three.

The work management process is a uniform, graded approach to safely and effectively manage work that impacts facility operations. This process ensures that work is properly identified, planned, scheduled, safely performed, and completed. Emphasis is also placed on maintenance of configuration control in the facility, in addition to proper work management for facilities and equipment. The definition of work includes modification and construction work, and corrective, preventive, and predictive maintenance.

As a by-product of the modeling initiative, several "quick hits" identifying problem areas or gaps were identified. Potential solutions or "fixes" to these are included as well; both are presented in Sections 4.1.2 and 4.1.3, respectively.

\subsubsection{Significant Problems/Gaps}

The major problems and gaps, identified from discussions and/or interviews with various TWRS personnel, that appear in the processes studied are as follows.

- Many people confuse the process and/or a lack of understanding of the process (work management) with the automated system (Job Control System); they assume that the system is the process.

- A "cover yourself" attitude of getting all signatures that are printed on the form, regardless of relevance to the task; this attitude is not conducive to accomplishment of tasks, goals, etc., in a cost-effective and efficient manner. 
- Differences in "labeling" standards between WTF and East Tank Farms is a source of confusion and/or misidentification that can create unnecessary safety risks and increase the expenses associated with $0 \& \mathbf{M}$.

- Cognizant managers and engineers (COG) are spread out over the Hanford Site; identifying specific COGs for an area(s) of responsibility is a problem which results in unnecessary time delays.

- Organizations are constantly changing; names often do not reflect their purpose or scope -- another source of confusion, wasted time, and increased cost.

- Procedures do not map to actual requirements and vice versa; a matrix of procedures vs requirements is not available for reference. Work that is required may not be accomplished in a correct or safe manner; at the other extreme, unnecessary work may be performed, thus increasing risks and cost.

- Approved work packages are required for performance of many simple tasks where a data sheet would suffice -- another factor contributing to wasted time and increased costs.

- Lack of consistent procedures among TWRS organizations; conflict between site procedures and tank farms procedures. This lack of consistency increases time and cost when procedures have to be individually verified for performance of the same type of work or maintenance on the same item of equipment at different tacilities.

- Too much time is spent writing/rewriting procedures; this is a result of a lack of consistency and configuration management. The amount of time that is expended writing/rewriting procedures could be more effectively spent accomplishing work.

- A lack of coordination in scheduling preventive maintenance (PM). Currently, PM may be scheduled at inopportune times, or scheduled on an item of equipment that is either identified for deactivation or already deactivated.

\subsubsection{Next Steps/Recommendations}

Next steps and/or recommendations for process improvement include the following.

- Review all current processes, in detail, for "value added;" if none is identified, discontinue the specific process(es) or step(s) that do not add value.

- Bring labeling standards for all areas of TWRS under configuration management; establish labeling standards compatible with all TWRS assets. 
- Bring TWRS procedures, common to all areas, under configuration managēment.

- Reorganize various disciplines/skills in a team or matrix structure to support specific processes, especially those that require a lot of coordination and/or interaction. Colocate team members in close proximity to their respective areas of responsibility.

- Avoid reorganizations that do not add value to a process; update organizational references in Hanford Info, Look-Up, PeopleCore, etc. in a timely manner. Old and new names should reflect their charter/purpose.

- Create a matrix map that allows traceability of procedures to real requirements (ones that can be documented) and vice versa; make this document readily available to all TWRS organizations for reference. Discontinue procedures that do not have a pedigree.

- Give the crafts personnel credit for knowing their respective trades; do not micromanage simple, non-critical tasks. Use data sheets in lieu of work packages whenever possible.

\subsection{DPM}

The DPM, Figure 4-1, depicts the main events, participants, and products of the work management process. The work management process consists of the following events:

- Work Originated

- Work Screened

- Work Package Prepared

- Pre-Work Reviewed

- Work Scheduled

- Work Released

- Work Performed

- Work Completed and Reviewed

- Work Post-Reviewed.

Each participant and its associated event(s) is described in Sections 4.4 and 4.5 , respectively.

\subsection{ORM}

The ORM, Figure 4-2, depicts the relationships between the participants, as objects, within the model. 


\subsection{DPM DICTIONARY}

The events are presented in Table 4-1 as they occur in the DPM from left to right. The reference number (a unique identifier) is depicted on all DPMs/ORMs.

\subsection{ORM DICTIONARY}

The participants in the ORM are presented alphabetically in Table 4-2 for ease of location. The reference number (a unique identifier) is depicted on all DPMs/ORMs. 


\section{WHC-SD-WM-PD-048 REV 0}

Figure 4-1. Work Management Dynamic Process Model. (3 sheets)

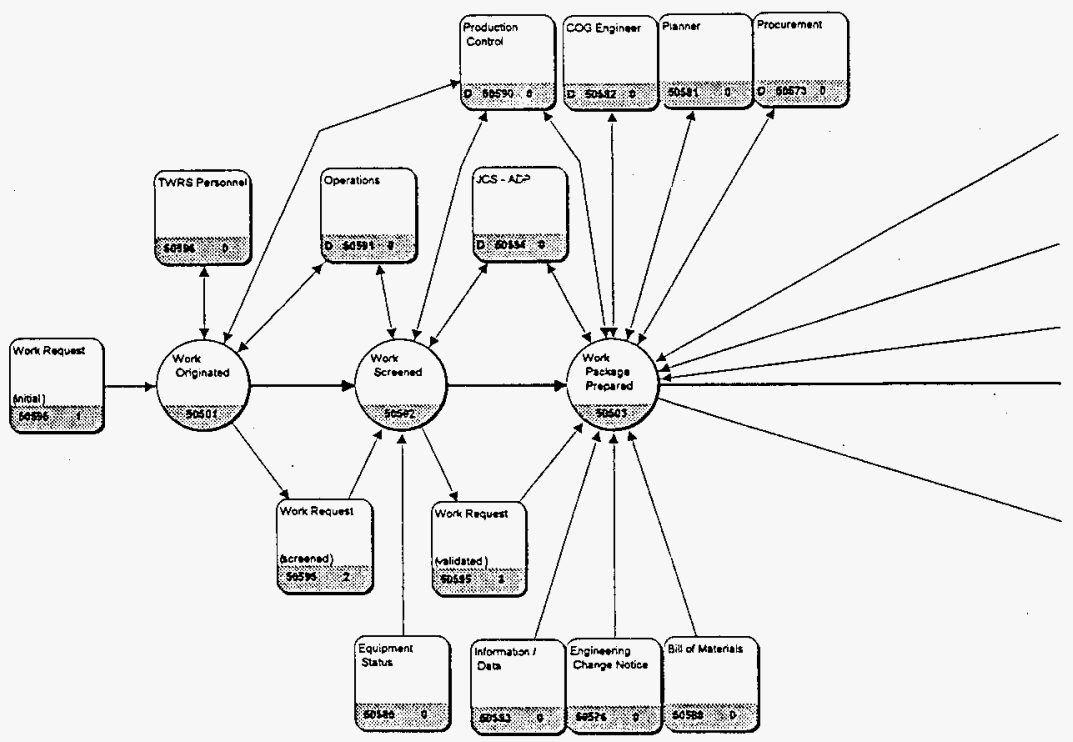


Figure 4-1. Work Management Dynamic Process Model. (3 sheets)

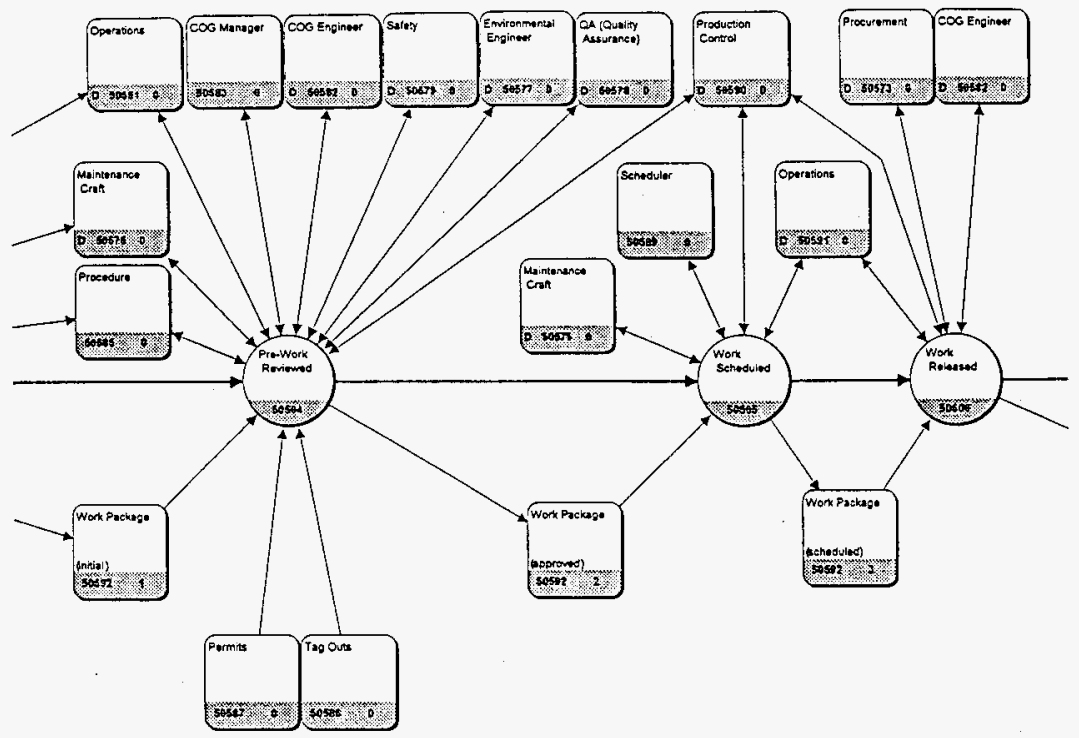




\section{WHC-SD-WM-PD-048 REV 0}

Figure 4-1. Work Management Dynamic Process Model. (3 sheets)

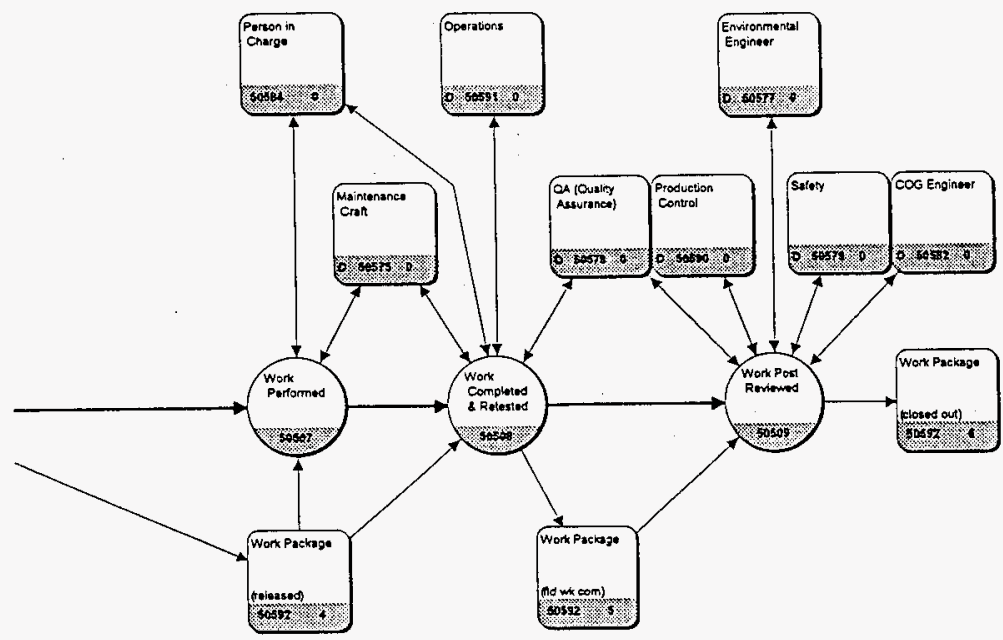




\section{WHC-SD-WM-PD-048 REV 0}

Figure 4-2. Work Management Object Relationship Model. (3 sheets)

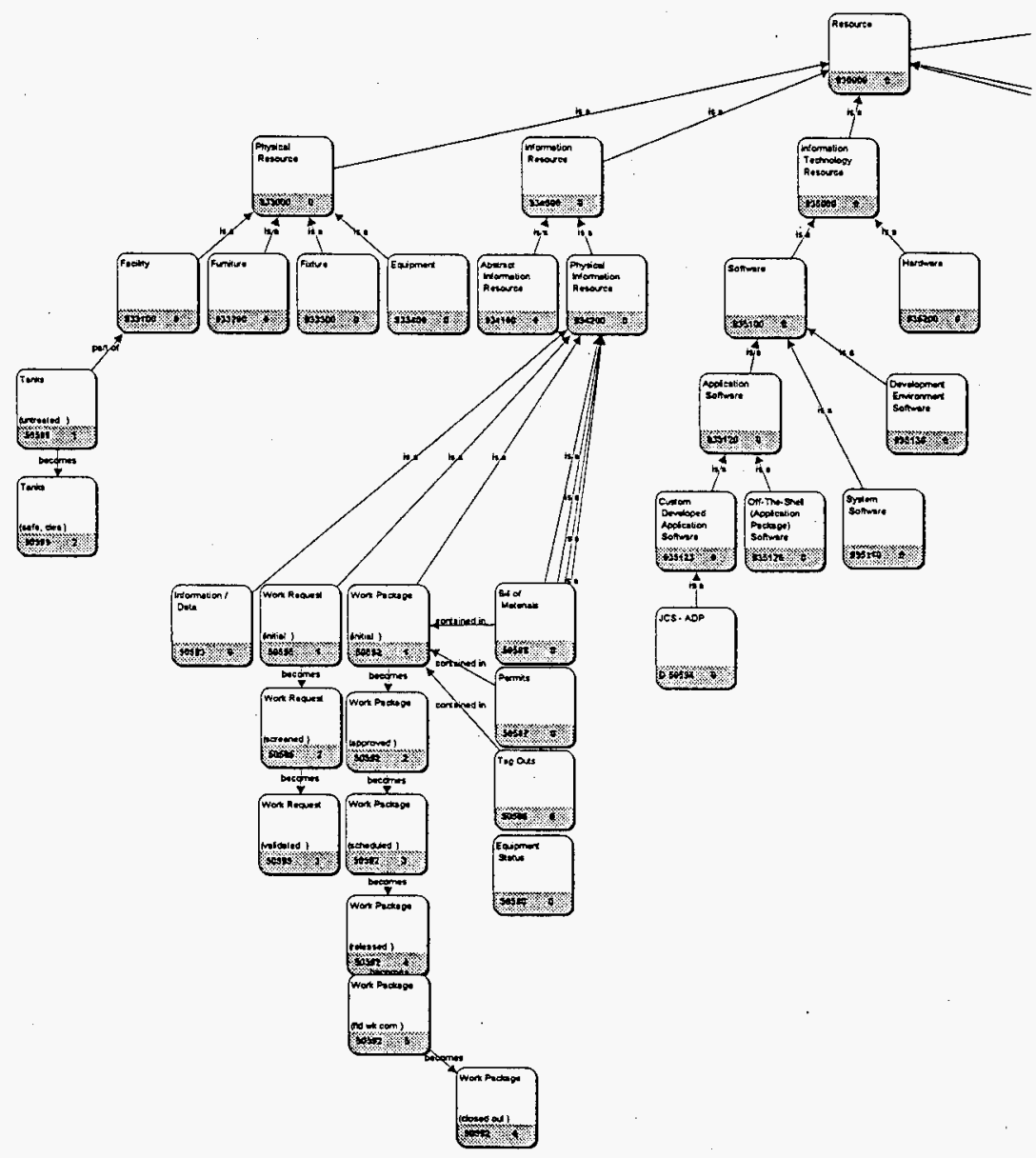




\section{WHC-SD-WM-PD-048 REV 0}

Figure 4-2. Work Management Object Relationship Model. (3 sheets)

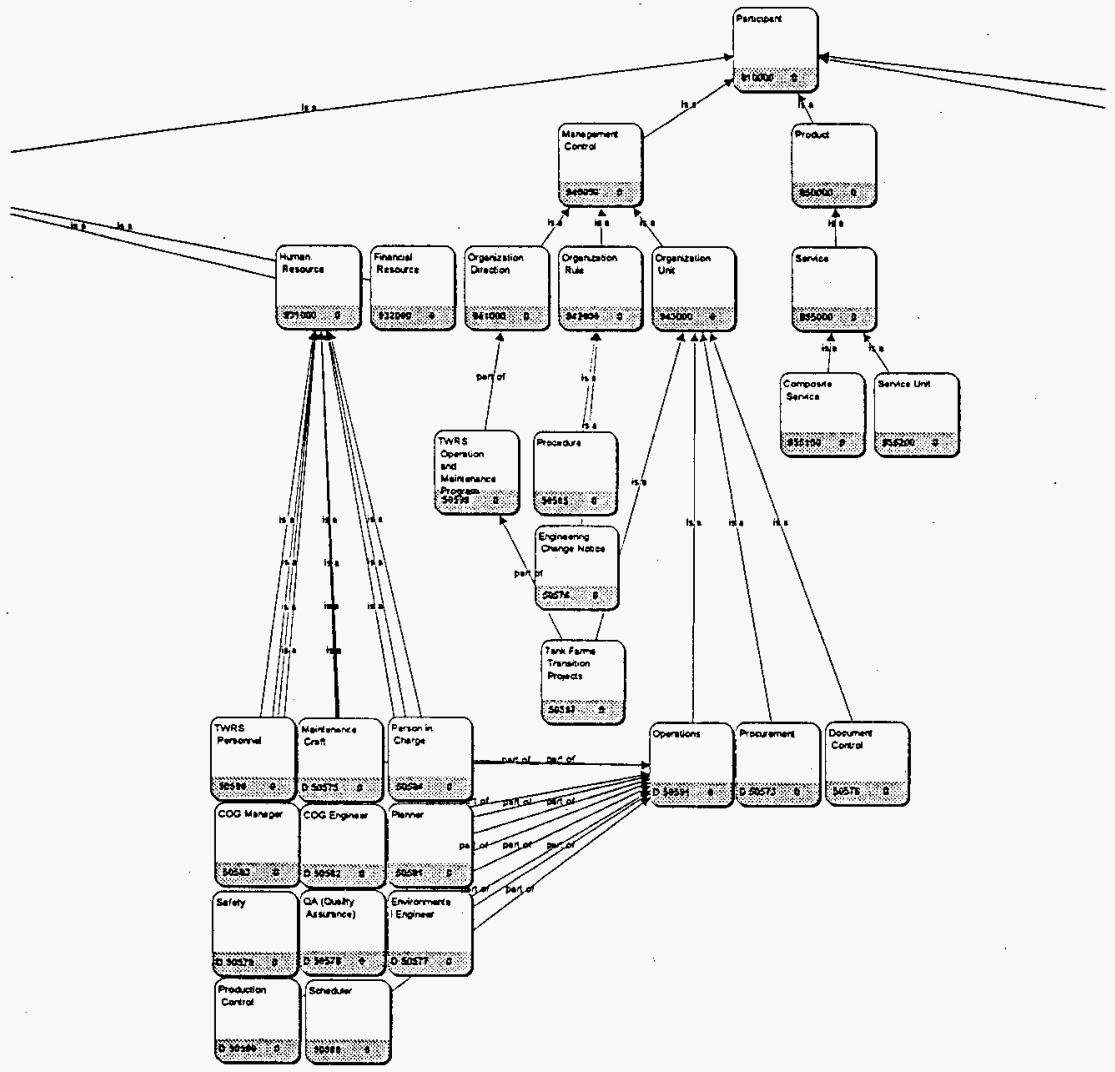




\section{WHC-SD-WM-PD-048 REV 0}

Figure 4-2. Work Management Object Relationship Model. (3 sheets)

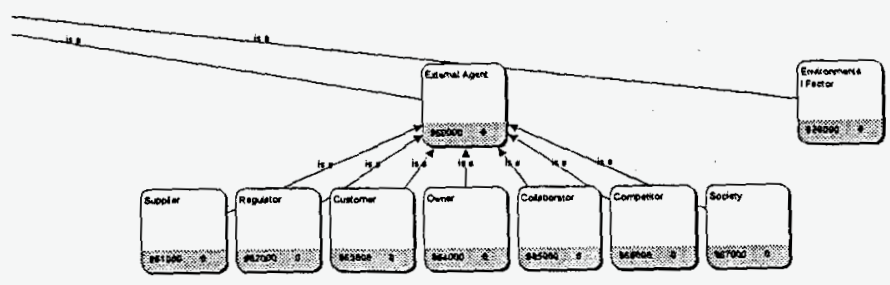


Table 4-1. Dynamic Process Model Dictionary. (4 sheets)

\begin{tabular}{|c|c|c|}
\hline Event name & Ref. \# & Event description \\
\hline $\begin{array}{l}\text { Pre-Work } \\
\text { Reviewed }\end{array}$ & 50504 & $\begin{array}{l}\text { Necessary supporting paperwork, such as tagout, permits, and jumper/lifted lead authorizations, are } \\
\text { drafted and placed in the work package. A field walkdown verification of the approved package is } \\
\text { performed by a walkdown team before scheduling. The minimal walkdown team consists of a work } \\
\text { package preparer and one person from the work group to be involved in the work. Discrepancies in } \\
\text { the documents defining the work safety envelope and actual conditions must be resolved before work } \\
\text { release. }\end{array}$ \\
\hline $\begin{array}{l}\text { Work } \\
\text { Completed \& } \\
\text { Retested }\end{array}$ & 50508 & $\begin{array}{l}\text { The Engineering Change Notice is closed out when the modification is completed as designed before } \\
\text { testing, unless it contains testing requirements. Before accepting modified systems or equipment, } \\
\text { operating and maintenance procedures must be updated. Associated operations and maintenance } \\
\text { training must also be completed. } \\
\text { Maintenance testing of the serviced equipment is performed as specified in the work package to } \\
\text { ensure the equipment is ready for operations functional testing. In many cases, maintenance testing } \\
\text { of the serviced equipment and operations functional testing may be combined into a single } \\
\text { post-maintenance test. The PIC or supervisor ensures any technical or procedural "lessons learned" } \\
\text { are included in the work package for future similar work activities. Items or actions needed for } \\
\text { work history are recorded. } \\
\text { The system or equipment is tested for operations acceptance as directed by the work package. } \\
\text { Operations post-maintenance tests may consist of preventive maintenance procedures, calibration } \\
\text { procedures, or compliance procedures to ensure the system is restored to system design parameters. } \\
\text { Once accepted for operational use, the system or equipment is then restored to service, as directed } \\
\text { by operations. }\end{array}$ \\
\hline Work Originated & 50501 & $\begin{array}{l}\text { Work is originated when a TWRS employee identifies a condition that needs correction; this can } \\
\text { either be an ad hoc event or planned maintenance. Work may be identified and originated by } \\
\text { various means, including telephone, verbally, work request, or document, or through a recall } \\
\text { system. The originator of the request reports the condition with sufficient information to allow the } \\
\text { request to be validated for need, and screened for priority and need. }\end{array}$ \\
\hline
\end{tabular}


Table 4-1. Dynamic Process Model Dictionary. (4 sheets)

\begin{tabular}{|c|c|c|}
\hline Event name & Ref. \# & Event description \\
\hline $\begin{array}{l}\text { Work Package } \\
\text { Prepared }\end{array}$ & 50503 & $\begin{array}{l}\text { Work package preparation, or planning, consists of job planning, obtaining the required reviews and } \\
\text { approvals, and assembling the work package. } \\
\text { Job planning includes the following tasks: (1) walking down the job site as needed and preparing } \\
\text { the work instructions; (2) a work review by plant forces (to comply with the Davis-Bacon Act of } \\
\left.1931^{\circ}\right) \text {; (3) a review of environmental requirements; (4) configuration management of operating, } \\
\text { maintenance, and surveillance procedures, and operations and maintenance training; } \\
\text { (5) identification and procurement of materials/parts required; and (6) identification and control of } \\
\text { tools and equipment required for work performance. } \\
\text { Work package review and approval consists of a review of the preparer's comments, the validation } \\
\text { of all approprjate work instructions, and a verification of all required approval signatures. } \\
\text { Work package assembly consists of compiling the approved work instructions and the necessary } \\
\text { documentation required to perform the work. Work packages may include design documents, } \\
\text { ALARA and hazardous waste management practices and techniques, bill of materials, and necessary } \\
\text { permits and special procedures. }\end{array}$ \\
\hline Work Performed & 50507 & $\begin{array}{l}\text { All work is issued or released with the employee's safety in mind. A pre-job safety briefing shall } \\
\text { be given corresponding to the level of work to be done. The worker reviews the work instructions } \\
\text { before working. If work cannot be performed as described, the problem is resolved before } \\
\text { continuing work. Work is supervised by the first-line craft manager or coordinated by a PIC. The } \\
\text { PIC coordinates the task and ensures it is performed accurately and in compliance with the } \\
\text { requirements specified in the work package. }\end{array}$ \\
\hline $\begin{array}{l}\text { Work } \\
\text { Post-Reviewed }\end{array}$ & 50509 & $\begin{array}{l}\text { Post-work review ensures the work was performed correctly and completely. All completed work } \\
\text { documents are reviewed before archiving to identify items important to operations, safety, quality, } \\
\text { or environmental protection concerns. Any technical or procedural "lessons learned" are reviewed } \\
\text { for future similar work activities. }\end{array}$ \\
\hline Work Released & 50506 & $\begin{array}{l}\text { Formal work release may not be required in some cases due to the rigor of the assigned work. } \\
\text { Work release includes establishing safe working conditions necessary to perform the job and the } \\
\text { proper system or equipment configuration for the facility to support the work. Work performance is } \\
\text { authorized by formal release once systems are properly lined up and safe working conditions have } \\
\text { been established. }\end{array}$ \\
\hline
\end{tabular}


Table 4-1. Dynamic Process Model Dictionary. (4 sheets)

\begin{tabular}{|c|c|c|}
\hline Event name & Ref. \# & Event description \\
\hline Work Scheduled & 50505 & $\begin{array}{l}\text { The weekly schedule is built and presented at a weekly meeting. A "look ahead" schedule is drafted } \\
\text { to begin preparation for the next week's schedule. Scheduling is divided into several sub-steps. } \\
\text { - Review work package requirements. } \\
\text { Prioritize the work. } \\
\text { Determine resource availability. } \\
\text { - Sevelop the schedule. } \\
\text { Each work package is reviewed to ensure it is "ready to work." These reviews include the required } \\
\text { facility conditions to ensure there is no evolution or other work which may interfere with work } \\
\text { performance. Equipment, tools, and materials required are present or arranged to be available } \\
\text { before scheduling. Personnel resource availability is obtained through the craft managers. } \\
\text { Training, vacation, holidays, and sick time must be considered before drafting the schedule. } \\
\text { Operations conveys management direction to meet facility goals by establishing priorities. } \\
\text { Operations reviews the "ready to work" packages for scheduling priorities. These may be divided } \\
\text { into priority work which will be hard-scheduled, and "fill-in" work, which may be coordinated by } \\
\text { the craft manager. Relative priorities are assigned for those ready to work the next scheduling } \\
\text { cycle. } \\
\text { It is preferred that the resources (people, tools, equipment, or materials) be made available before } \\
\text { scheduling. Arranging resource availability requires coordination and communication between the } \\
\text { supplier and the facility representative. } \\
\text { The work is scheduled based on the relative priorities of each work package and resource } \\
\text { availability. Firmly scheduling } 60 \% \text { to } 70 \% \text { of the personnel resources for work ensures that vital } \\
\text { work is performed and provides a ready source of personnel for emergent work. It also } \\
\text { compensates for sick time and emergency leave situations without affecting the schedule. } \\
\text { After generating the weekly schedule, the key resource providers meet to review the schedule and } \\
\text { discuss issues at a Plan of the Week meeting. Priorities of scheduled jobs and coordination issues } \\
\text { are addressed. }\end{array}$ \\
\hline
\end{tabular}


Table 4-1. Dynamic Process Model Dictionary. (4 sheets)

\begin{tabular}{|l|l|l|}
\hline Event name & Ref. \# & \multicolumn{1}{c|}{ Event description } \\
\hline Work Screened & 50502 & $\begin{array}{l}\text { The request is reviewed by a screener for the area, facility, or plant responsible for resolving the } \\
\text { request to ensure it is valid. A valid work request means the request is not a duplicate of a previous } \\
\text { request, the work supports the facility mission, funding is available, and the request contains the } \\
\text { information needed to start planning, if required. Valid work requests are assigned a unique number } \\
\text { and placed into the JCS for tracking. } \\
\text { Valid requests are also assigned a priority which determines the sequence in which they will be } \\
\text { processed. A systematic method of determining job priority based on risk consists of two factors: } \\
\text { The importance of the identified work item based on safety, environmental, and facility } \\
\text { concerns } \\
\text { The urgency of performing the work; this involves consideration of the consequences of not } \\
\text { performing the work in a timely manner, if at all. } \\
\text { The screening process evaluates the level of planning required and records needs for the identified } \\
\text { work. Formal planning may not be required for routine tasks; however, planning is required if the } \\
\text { work is not routine, or when there are no approved procedures. Other criteria controlled by the } \\
\text { facility provide specific guidelines which define when planning is required. When screened, active } \\
\text { work requests are validated, placing them in the maintenance backlog. }\end{array}$ \\
\hline
\end{tabular}

Davis Bacon Act of 1931, 40 USC 276a, et seq.
ALARA = As low as reasonably achievable
JCS = Job Control System
PIC $=$ Person in charge
TWRS $=$ Tank Waste Remediation System 
Table 4-2. Object Relationship Model Dictionary. (4 sheets)

\begin{tabular}{|c|c|c|}
\hline Participant name & Ref. \# & Participant description \\
\hline Bill of Materials & 50588 & $\begin{array}{l}\text { A list of materials required to perform a task; used by Procurement to start the material acquisition } \\
\text { process. }\end{array}$ \\
\hline COG Manager & 50583 & The manager responsible for a process, facility, etc. \\
\hline COG Engineer & 50582 & The engineer responsible for a process, facility, etc. \\
\hline $\begin{array}{l}\text { Engineering } \\
\text { Change Notice }\end{array}$ & 50574 & $\begin{array}{l}\text { A form used to document, approve, and control changes to engineering documents (see } \\
\text { WHC-CM-6-1, EP-2.21). }\end{array}$ \\
\hline $\begin{array}{l}\text { Environmental } \\
\text { Engineer }\end{array}$ & 50577 & $\begin{array}{l}\text { An engineer who is responsible for ensuring environmental compliance with all pertinent } \\
\text { environmental rules and regulations. }\end{array}$ \\
\hline $\begin{array}{l}\text { Equipment } \\
\text { Status }\end{array}$ & 50580 & $\begin{array}{l}\text { The status of any process required or associated equipment that is involved in a current or } \\
\text { subsequent related event; specifically the status of TWRS equipment associated with normal } \\
\text { operations or required to perform a specific task. }\end{array}$ \\
\hline $\begin{array}{l}\text { Information/ } \\
\text { Data }\end{array}$ & 50593 & $\begin{array}{l}\text { Represents information and/or data relevant to assembly of the work package or included in the } \\
\text { prepared work package. This may include design documents and/or drawings, ALARA and } \\
\text { hazardous waste management practices and techniques, bill of materials, and necessary permits and } \\
\text { special procedures. }\end{array}$ \\
\hline $\begin{array}{l}\text { JCS (Job } \\
\text { Control System) }\end{array}$ & 50594 & $\begin{array}{l}\text { Computerized maintenance management system developed at the Hanford Site to support the work } \\
\text { management process as defined in WHC-CM-1-8. }{ }^{2} \text { JCS contains information regarding components } \\
\text { (equipment), preventive maintenance/surveillance activities, and work activity from identification } \\
\text { through closeout. JCS has the capability to status and track the work and report pre-defined } \\
\text { performance metrics, and can be used as a short-term schedule for work to be performed. }\end{array}$ \\
\hline $\begin{array}{l}\text { Maintenance } \\
\text { Craft }\end{array}$ & 50575 & $\begin{array}{l}\text { TWRS maintenance personnel who perform manual labor (electricians, pipe fitters, etc.) to install, } \\
\text { modify, and maintain TWRS facilities and/or equipment. In the context of this document, it also } \\
\text { includes the craft managers. }\end{array}$ \\
\hline Operations & 50591 & $\begin{array}{l}\text { The operations manager of a facility or area or, where no operations manager is assigned, the } \\
\text { manager designated by the building manager as responsible for ensuring safe operation and } \\
\text { maintenance of the facility or building. Responsibilities include providing management direction to } \\
\text { meet facility goals, reviewing "ready to work" packages, performing functional testing, etc. }\end{array}$ \\
\hline
\end{tabular}


Table 4-2. Object Relationship Model Dictionary. (4 sheets)

\begin{tabular}{|c|c|c|}
\hline Participant name & Ref. \# & Participant description \\
\hline Permits & 50587 & $\begin{array}{l}\text { A special dispensation to perform a job, work, or task. Permit authorizations are included on each } \\
\text { permit form; these signatures certify the conditions contained on the permit are appropriate to allow } \\
\text { work performance. }\end{array}$ \\
\hline $\begin{array}{l}\text { Person in } \\
\text { Charge (PIC) }\end{array}$ & 50584 & $\begin{array}{l}\text { An individual assigned responsibility for coordinating, directing, and monitoring the performance of } \\
\text { a work package. PIC training and qualifications are provided by the affected facility. }\end{array}$ \\
\hline Planner & 50581 & $\begin{array}{l}\text { The person responsible for planning facility (or site) work, maintenance, etc. Responsible for } \\
\text { detailed planning of tasks, including the act of preparing, reviewing, and approving the work } \\
\text { instructions and assembling the work package. }\end{array}$ \\
\hline Procedure & 50585 & $\begin{array}{l}\text { A documented method(s) for accomplishing a specific task, job, or work, designed to ensure } \\
\text { repeatability of a process or processes. }\end{array}$ \\
\hline Procurement & 50573 & $\begin{array}{l}\text { The organization responsible for ordering parts, materials, etc., requested by various other } \\
\text { organizations via a Bill of Materials. Orders for materials and/or parts are most frequently initiated } \\
\text { during the Work Package Prepared or Work Package Released events. }\end{array}$ \\
\hline $\begin{array}{l}\text { Production } \\
\text { Control }\end{array}$ & 50590 & $\begin{array}{l}\text { That organization within Operations responsible for the effectiveness of the work package } \\
\text { preparation, approval, tracking, and post-work review processes. }\end{array}$ \\
\hline $\begin{array}{l}\text { QA (Quality } \\
\text { Assurance) }\end{array}$ & 50578 & $\begin{array}{l}\text { An engineer who is responsible for overseeing compliance with all pertinent quality and } \\
\text { configuration management standards and procedures. }\end{array}$ \\
\hline Safety & 50579 & $\begin{array}{l}\text { An engineer who is responsible for overseeing compliance with all pertinent safety rules, } \\
\text { regulations, practices, and requirements. }\end{array}$ \\
\hline Scheduler & 50589 & The Operations representative who is responsible for establishing a schedule of job tasks to be done. \\
\hline Tag Outs & 50586 & $\begin{array}{l}\text { A tag indicating that an item of equipment is not operational because of a material or safety } \\
\text { concern. }\end{array}$ \\
\hline $\begin{array}{l}\text { TWRS } \\
\text { Personnel }\end{array}$ & 50596 & Represents any TWRS employee who originates or identifies a need for work to be accomplished. \\
\hline
\end{tabular}


Table 4-2. Object Relationship Model Dictionary. (4 sheets)

\begin{tabular}{|c|c|c|}
\hline Participant name & Ref. \# & Participant description \\
\hline Work Package & 50592 & $\begin{array}{l}\text { Contains all work elements prescribed in WHC-CM-3-5, Section } 12.7,{ }^{3} \text { to perform the job; this } \\
\text { includes all approved work instructions and the necessary documentation, such as drawings, memos, } \\
\text { specifications, procedures, design documents, ALARA and hazardous waste management practices } \\
\text { and techniques, Bill of Materials, necessary permits and special procedures, etc., required to } \\
\text { perform the work. The work package is organized around the work document, the main form used } \\
\text { to identify, screen, plan, release, perform, retest, and complete work. } \\
\text { Work packages are associated with seven events: Work Package Prepared, Pre-Work Reviewed, } \\
\text { Work Scheduled, Work Released, Work Performed, Work Completed and Retested, and Work } \\
\text { Post-Reviewed, and occur in six different states as follows: } \\
\text { Initial - The Work Package (initial) is the output from the Work Package Prepared event; at } \\
\text { this point, job planning, review and approval, and work package assembly have been } \\
\text { accomplished. } \\
\text { Approved - The Work Package (approved) state is the output from the Pre-Work Reviewed } \\
\text { event. Necessary supporting documents have been added and a field walkdown verification of } \\
\text { the work package has been accomplished; discrepancies, if any, have been identified. } \\
\text { - Scheduled - The Work Package (scheduled) state is the output from the Work Scheduled } \\
\text { event. The work package is placed on a weckly schedule and each package is reviewed to } \\
\text { ensure that it is "ready to work." The priority is reviewed and resources assigned. } \\
\text { - Released - The Work Package (released) state is the output from the Work Released event. } \\
\text { Release indicates that safe working conditions necessary to perform the job, and the proper } \\
\text { system or equipment configuration for the facility to support the work, have been verified. } \\
\text { Completed and Retested event. The Engineering Change Notice is closed out when the } \\
\text { modification is completed as designed before testing, unless it contains testing requirements. } \\
\text { The PIC or supervisor ensures any technical or procedural "lessons leamed" are included in } \\
\text { the work package for future similar work activities. Items or actions needed for work history } \\
\text { are recorded. }\end{array}$ \\
\hline
\end{tabular}


Table 4-2. Object Relationship Model Dictionary. (4 sheets)

\begin{tabular}{|l|l|l|l|}
\hline $\begin{array}{l}\text { Participant name } \\
\text { (cont) }\end{array}$ & Ref. \# & $\begin{array}{l}\text { Participant description } \\
\text { (cont) }\end{array}$ & $\begin{array}{l}\text { Closed out - The Work Package (closed out) state is the output from Work Post-Reviewed } \\
\text { event. All completed work documents are reviewed before archiving to identify items } \\
\text { important to operations, safety, quality, or environmental protection concerns. Any technical } \\
\text { or procedural "lessons learned" are reviewed for future similar work activities. }\end{array}$ \\
\hline Work Request & 50595 & $\begin{array}{l}\text { Work requests are associated with two events: Work Originated and Work Screened, and occur in } \\
\text { the following different states: }\end{array}$ \\
\hline \multirow{\infty}{*}{$\begin{array}{l}\text { Initial - TWRS employees identify the need for work by reporting a condition requiring } \\
\text { corrective action via submission of a blank J-form (J-1 by default, or J-2 or J-3 by selection). } \\
\text { Screened - The information contained on the form is reviewed for adequacy and accuracy, and } \\
\text { for submission on the correct J-form. } \\
\text { Validated - A determination is made if the work is necessary and/or if the request is a } \\
\text { duplicate of an open item; if either condition is true, the work is rejected. Finally, the work } \\
\text { priority is established. }\end{array}$} \\
\hline
\end{tabular}

'WHC-CM-6-1, Standard Engineering Practices, Westinghouse Hanford Company, Richland, Washington.

${ }^{2}$ WHC-CM-1-8, Work Management Manual, Westinghouse Hanford Company, Richland, Washington.

${ }^{3}$ WHC-CM-3-5, Document Control and Records Management Manual, Westinghouse Hanford Company, Richland, Washington.
ALARA $=$ As low as reasonably achievable
COG $=$ Cognizant manager and engineer
JCS = Job Control System
PIC = Person in charge
QA $=$ Quality assurance
TWRS = Tank Waste Remediation System 


\subsection{WTF REENGINEERING SIMULATION}

\subsection{EXECUTIVE SUMMARY}

This section presents an overview of the simulation performed on behalf of the WTF reengineering effort. The objective was to (1) simulate the current or As-Is processes of the WTF; (2) compare the simulated results obtained from the model with metrics of the actual results currently achieved; and (3) create a simulation model of the To-Be or desired organizational processes to postulate the time, level of effort, and organization required to reduce the work planning document cycle by a significant amount.

\subsubsection{Overview}

West Tank Farms, as part of its reengineering effort, identified 11 goals it wanted to achieve to create and maintain a clean, safe, and stable operating environment. The two goals identified as being candidates for simulation are as follows.

- Reduce the detailed work planning preparation cycle time by $50 \%$.

- Reduce the number of jobs/tasks requiring detailed planning by $80 \%$.

To establish a high level of confidence in the simulation effort, a decision was made to create a simulation model of the existing or As-Is processes as a baseline of current performance. This simulation baseline would also be compared to metrics of the existing processes to validate the simulation modeling techniques and methods. Various models of the reengineered processes (To-Be models) would then be created as simulation models to prepare time and cost estimates for comparison with the As-Is simulation results. The simulation model achieving the best reduction of cost and time over the As-Is would then be implemented.

The first goal identified for simulation was the reduction in the work planning preparation cycle. Presently, the simulation process (both As-Is and the To-Be) has been frozen. The As-Is process simulation model has been suspended in the validation mode; the first (simulation) model of the To-Be has been completed and is also in a suspended state. Work on this effort was discontinued when the decision was made by WTF to continue with its reengineering effort without the benefit of simulating and comparing the To-Be simulation models with the As-Is model of the, at the time, current processes. Even though simulation of the WTF work planning preparation process was overcome by events, the WTF Point of Contact, Antonio (Tony) Woods, was favorably impressed by the results and recommended that other TWRS organizations consider simulation modeling of their processes before implementing reengineering efforts. 


\subsubsection{Significant Problems/Gaps}

Problems identified during the simulation modeling effort for WTF parallel those previously identified in Section 4.1.2, and will not be repeated in this section. Additional problems or gaps, specific to this effort, are identified as follows:

- Overcoming the learning curve associated with the subtleties of the OPAL simulation modeling tool.

- Limited availability of the WTF knowledge expert to provide input and/or review assumptions made concerning model constructs during critical periods of simulation modeling.

- Not enough time allocated to the simulation effort before implementing the reengineering changes. In this case, information gained from the simulation process was not used.

\subsubsection{Next Steps/Recommendations}

Recommendations identified during the simulation modeling effort for WTF parallel those identified in Section 4.1.3, and will not be repeated in this section. Recommendations for process improvement, specific to this effort, are identified as follows.

- Use OPAL simulation experienced analysts on projects where a short time duration is a critical factor in successful completion of the simulation results.

- Assign customer knowledge experts who will be available whenever required for consultation on a high-priority basis.

- Ensure adequate time is allocated for information gathering, simulation modeling, and analysis of simulation results before organizational implementation of the To-Be architecture.

- Use experienced OPAL simulation analysts as mentors for developing simulation skills and techniques of untrained or inexperienced OPAL analysts.

\subsection{SIMULATION}

Before reviewing the simulation models for the WTF work processes, the tasks associated with the As-Is, To-Be, and "Transition" states of the simulation model should be

-OPAL is a trademark of DMR Group, Inc. 
understood as a prelude to how the simulation models were developed and what variables were considered in their construction.

\subsubsection{Simulation Tasks}

Top-level simulation tasks and their application to the respective model states for the WTF work process reengineering effort are indicated in Table 5-1.

Table 5-1. Simulation Tasks and their Application.

\begin{tabular}{|c|c|c|l|}
\hline As-Is & To-Be & Transition & \multicolumn{1}{|c|}{ Simulation tasks } \\
\hline $\mathrm{X}$ & & & Replicate current statistics on cycle time. \\
\hline $\mathrm{X}$ & & & $\begin{array}{l}\text { Demonstrate backlog of work packages in progress; indicate } \\
\text { total, number by event, and number by work package type. }\end{array}$ \\
\hline & $\mathrm{X}$ & & Describe the To-Be process. \\
\hline & $\mathrm{X}$ & $\mathrm{X}$ & $\begin{array}{l}\text { Donitor the availability of "pool" resources. } \\
\text { backlog, build up, cut over, and backlog reduction. }\end{array}$ \\
\hline $\mathrm{X}$ & $\mathrm{X}$ & $\mathrm{X}$ & $\begin{array}{l}\text { Account for different process times for different work package } \\
\text { types. }\end{array}$ \\
\hline $\mathrm{X}$ & $\mathrm{X}$ & $\mathrm{X}$ & \begin{tabular}{l} 
Account for the phased transition to the To-Be processes. \\
\hline
\end{tabular} \\
\hline $\mathrm{X}$ & $\mathrm{X}$ & $\begin{array}{l}\text { Focus on staff loading and cycle time; minimize the effect of } \\
\text { information technology. }\end{array}$ \\
\hline
\end{tabular}

\subsubsection{Simulation Models}

Simulation models of the As-Is and To-Be WTF work document processes are depicted in Figures 5-1 and 5-2, respectively. The As-Is has been validated; the To-Be is a first cut of one of the reengineering options depicting implementation of the team concept.

Dictionaries for either a DPM or an ORM do not exist for this simulation effort because of the time frame and the purpose (goals) of the simulation. Results of the simulation are only available in an electronic form; the simulation must be run to capture and/or view the results. 
Figure 5-1. West Tank Farms As-Is Work Document Processes. (3 sheets)

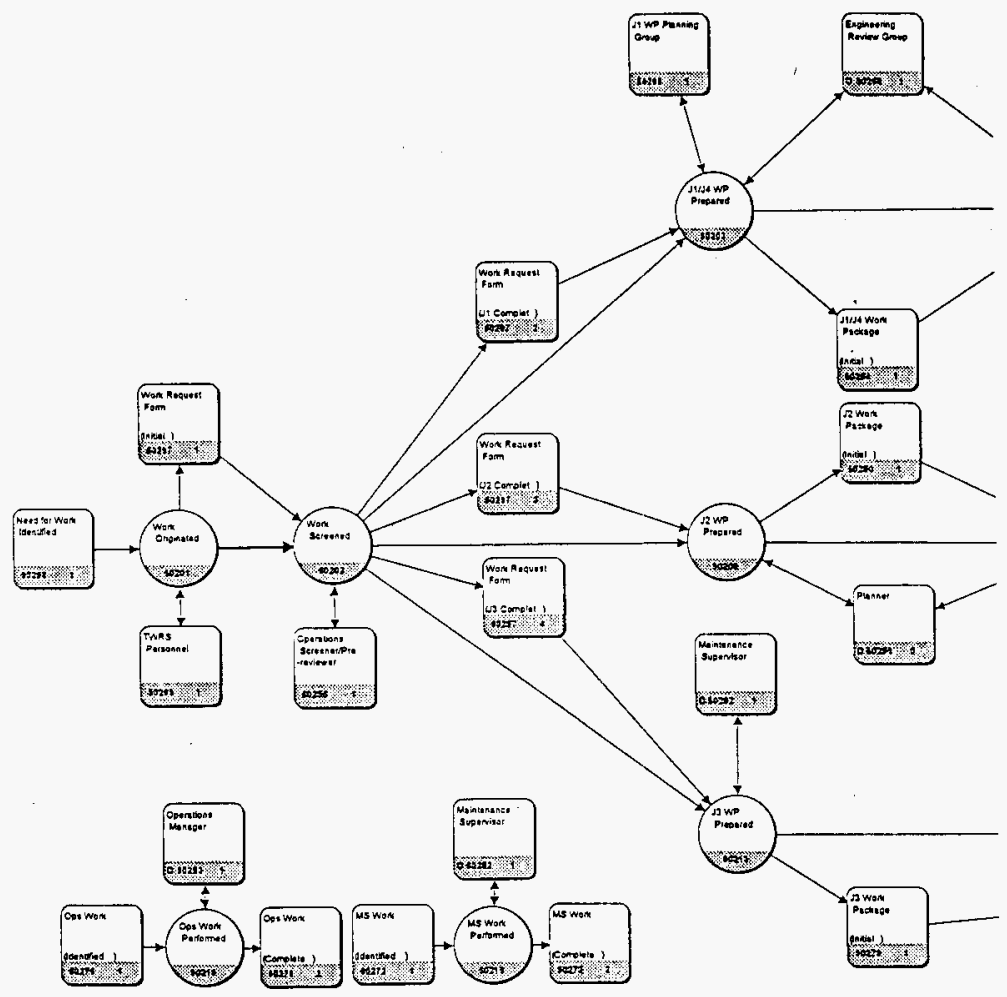


Figure 5-1. West Tank Farms As-Is Work Document Processes. (3 sheets)

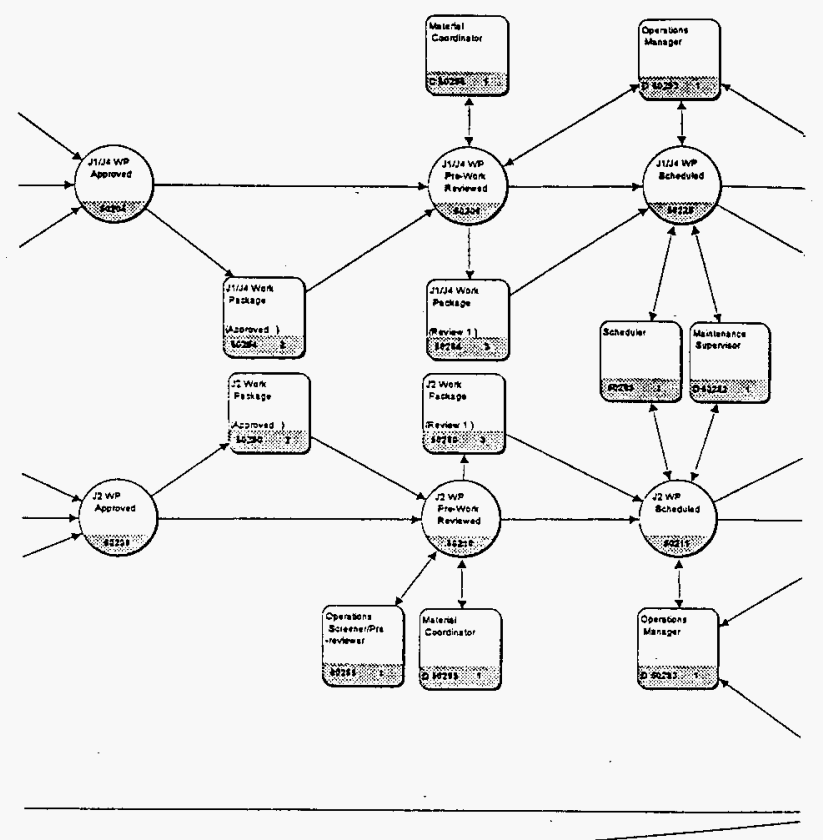


Figure 5-1. West Tank Farms As-Is Work Document Processes. (3 sheets)

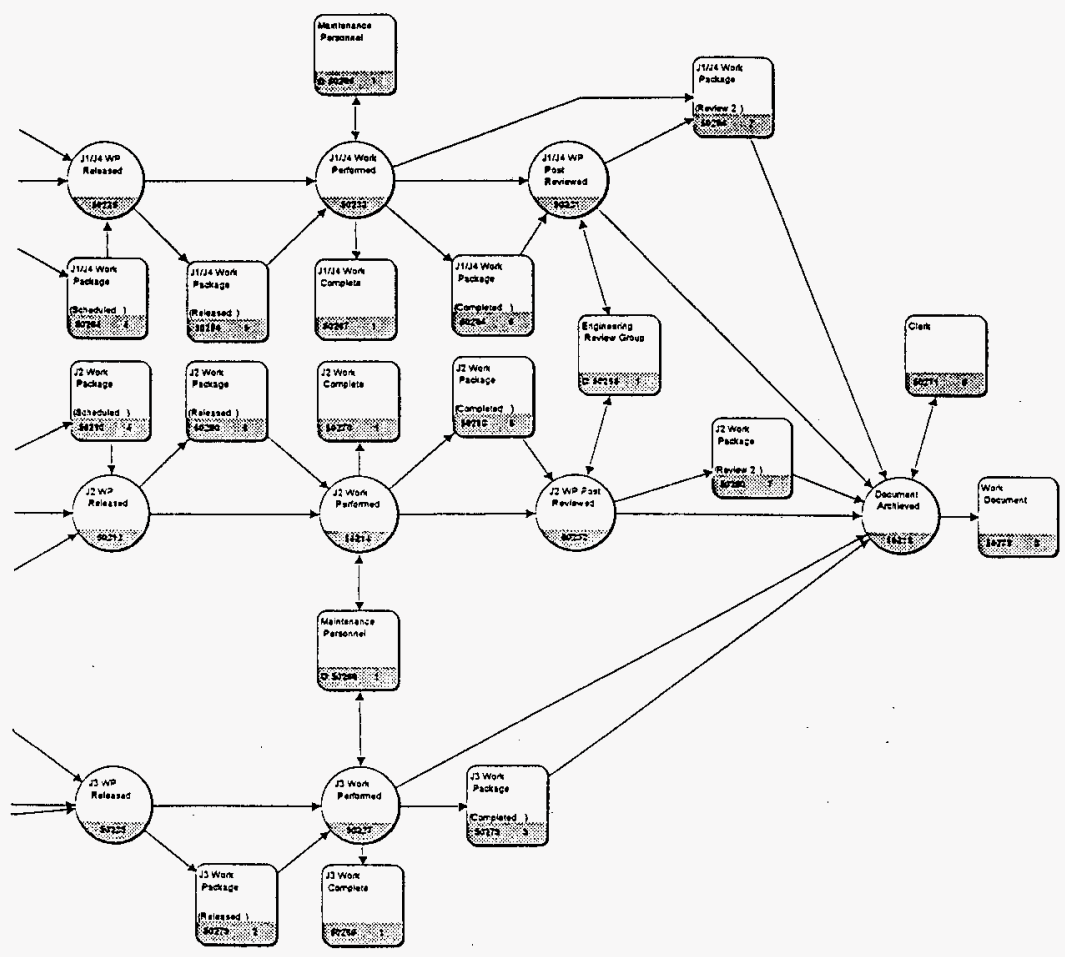


Figure 5-2. West Tank Farms To-Be Wor Document Processes.

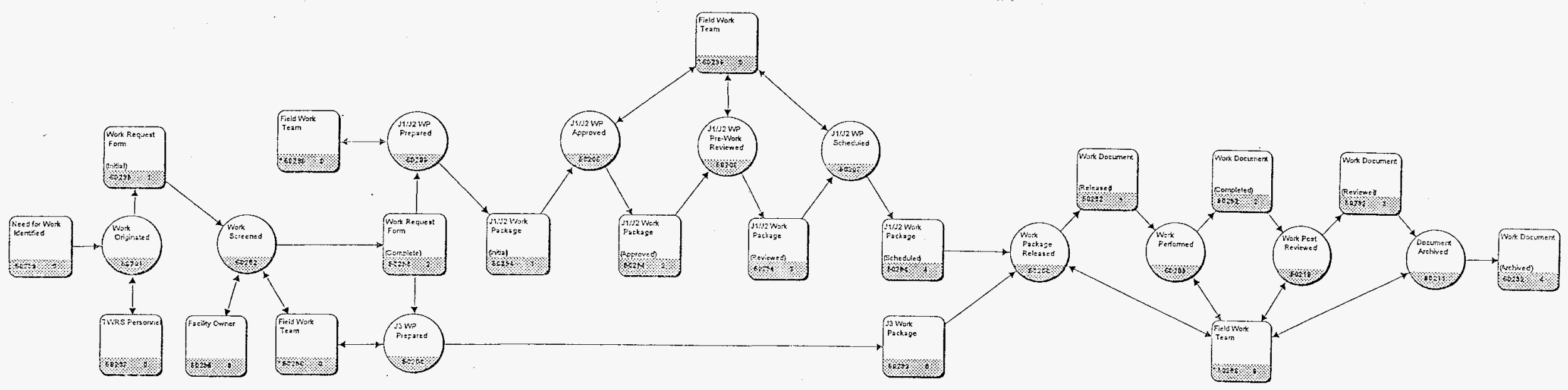




\section{WHC-SD-WM-PD-048 REV 0}

\subsubsection{Simulation Resources}

Types and location of resources for the WTF simulation are identified in Table 5-2.

Table 5-2. Simulation Resource Types and Locations.

\begin{tabular}{|c|c|}
\hline Resource type & Location \\
\hline OPAL simulation tips (Powerpoint) & 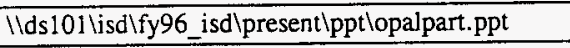 \\
\hline OPAL simulation model of the As-Is & IIds101 \isdlfy96_isdlo-m/workasislwtf_docl.dmp \\
\hline OPAL simulation model of the To-Be & \/ds101lisd\fy96_isdlo-m/worktobelwtf tobe.dmp \\
\hline As-Is data capture (EXCEL) & IIds101ไisdlfy96_isdlo-m\doc-asis\wtf_data.xls \\
\hline As-1s cost estimate (EXCEL) & Ilds101 lisdlfy96_isdlo-m\doc-asislwtf_cost.xls \\
\hline
\end{tabular}

EXCEL is a trademark of the Microsoft Corporation.

The identification and location of these file are provided as a resource for reference use only; they are not to be modified or used without the express permission of the owner. Contact the TWRS ISD Project Manager (Gus Calapristi, 509-372-2151) for authorization. 
)

WHC-SD-WM-PD-048 REV 0

This page intentionally left blank. 


\subsection{REFERENCES}

Carriera, R. J., 1995, TWRS Informarion Systems Definition Engineering Study and Implementation Plan, WHC-SD-WM-PLN-099, Rev. 0, Westinghouse Hanford Company, Richland, Washington.

Davis-Bacon Act of 1931, 40 USC 276a, et seq.

Ecology, EPA, and DOE, 1994, Hanford Federal Facility Agreement and Consent Order, as amended, Washington State Department of Ecology, U.S. Environmental Protection Agency, and U.S. Department of Energy, Olympia, Washington.

Legore, T., 1996, Tank Waste Remediation System Information Systems Definition Tank Characterization Report Generation Process As-Is, WHC-SD-WM-PD-045, Rev. 0, Westinghouse Hanford Company, Richland, Washington.

National Environmental Policy Act of 1969, 42 USC 4321, et seq.

Peck, L. G., 1996, TWRS Systems Engineering Management Plan, WHC-SD-WM-SEMP-002, Rev. 0, Westinghouse Hanford Company, Richland, Washington.

WHC-CM-1-8, Work Managemen Manual, Westinghouse Hanford Company, Richland, Washington.

WHC-CM-3-5, Document Control and Records Management Manual, Section 12.7, "Approval of Environmental, Safety, and Quality Affecting Documents," Westinghouse Hanford Company, Richland, Washington.

WHC-CM-4-2, Qualiny Assurance Manual, Westinghouse Hanford Company, Richland, Washington.

WHC-CM-6-1, Standard Engineering Pracrices, Section EP-2.2, "Engineering Document Change Control Requirements," Westinghouse Hanford Company, Richland, Washington. 


\section{WHC-SD-WM-PD-048 REV 0}

This page intentionally left blank. 


\section{DISTRIBUTION SHEET}

\begin{tabular}{|c|c|c|c|c|c|}
\hline \multirow{2}{*}{$\begin{array}{l}\text { To } \\
\text { Distribution }\end{array}$} & \multirow{2}{*}{\multicolumn{3}{|c|}{$\begin{array}{l}\text { From } \\
\text { Technical Staff }\end{array}$}} & \multicolumn{2}{|c|}{ Page 1 of 1} \\
\hline & & & & \multicolumn{2}{|c|}{ Date } \\
\hline \multirow{2}{*}{\multicolumn{4}{|c|}{$\begin{array}{l}\text { Project Title/Work Order } \\
\text { Information System Definition Architecture }\end{array}$}} & \multicolumn{2}{|c|}{ EDT No. $/ 4 / 260$} \\
\hline & & & & \multicolumn{2}{|c|}{ ECN No. } \\
\hline Name & MSIN & $\begin{array}{c}\text { Text } \\
\text { With All } \\
\text { Attach. }\end{array}$ & Text Only & $\begin{array}{l}\text { Attach./ } \\
\text { Appendix } \\
\text { Only }\end{array}$ & $\begin{array}{l}\text { EDT/ECN } \\
\text { Only }\end{array}$ \\
\hline
\end{tabular}

\section{Westinghouse Hanford Company}

\section{R. Adams}

B. J. Anderson

N. G. Awadalla

R. B. Bass

A. J. Calapristi

T. A. Gates

S. K. Genoni

R. L. Larson

T. Legore

G. C. Main

S. R. Nelson

J. D. Panasiti

W. J. Schlauder

Central files (orig. +1)

R2-12

H8-42

H6-35

$57-81$

H7 -32

H8-44

K $7-22$

$\mathrm{H} 8-41$

H8-44

H7 -32

B4 - 55

B3-50

S7-84

A3-88 $x$

$x$

$x$

$x$

$x$

$x$

$x$

$x$

$x$

$x$

$x$ 